Check for updates

Cite this: RSC Adv., 2021, 11, 22859

Received 5th May 2021

Accepted 13th June 2021

DOI: 10.1039/d1ra03513d

rsc.li/rsc-advances

\section{Recent advances in the transesterification of $\beta$-keto esters}

\author{
M. C. Hennessy (D) ab and T. P. O'Sullivan (D) *abc
}

The ability to selectively transesterify $\beta$-keto esters is a useful transformation in organic synthesis. The increasing interest in transesterification for the synthesis of compounds of pharmaceutical importance, as well as for biodiesel production, has led to the development of a variety of different approaches. This article aims to summarise recent advances in the transesterifications of $\beta$-keto esters. Particular interest has been paid to methodologies with minimal environmental impact.

\section{Introduction}

$\beta$-Keto esters contain both electrophilic and nucleophilic sites and so are important synthons in synthetic chemistry. They often constitute a core building block in complex medicinal compounds. ${ }^{1} \beta$-Keto esters represent key intermediates in the synthesis of complex molecules such as paclitaxel, prunustatin A, $( \pm)$-9-acetoxyfukinanolide and $( \pm)$-velloziolone ${ }^{2-5}$ (Fig. 1).

Direct transesterification obviates the need to produce intermediate carboxylic acids, which often display poor solubility in organic solvents. Additionally, $\beta$-keto acids are unstable and tend to decarboxylate readily. ${ }^{6} \mathrm{~A}$ wide range of methyl and ethyl esters are commercially available and represent convenient starting points for elaboration via transesterification. The transesterification of $\beta$-keto esters has widespread application in agrochemicals where transesterification of vegetable oil with alcohols has long been a preferred method for the production of biodiesel. ${ }^{78}$ Transesterification is a convenient method for modifying both simple and elaborate esters and is commonplace in both research and industry.

$\beta$-Keto ester groups may be selectively transesterified over other esters such as simple, $\alpha$-keto esters or $\gamma$-keto esters. ${ }^{9}$ Reactions which are selective for $\beta$-keto esters most likely proceed via an enol intermediate, as chelation between the two carbonyls to a catalyst heteroatom and the presence of an enolisable $\alpha$-proton is important. Alternatively, the formation of an acylketene intermediate, as proposed by Lawrie and Campbell, may also occur (Scheme 1). ${ }^{10}$

A broad range of viable reaction conditions has been developed for the transesterification of $\beta$-keto esters. ${ }^{11,12}$ The kinetics of transesterifications are typically slow, so a catalyst is normally

${ }^{a}$ School of Chemistry, University College Cork, Cork, Ireland.E-mail: tim.osullivan@ ucc.ie

${ }^{b}$ Analytical and Biological Chemistry Research Facility, University College Cork, Cork, Ireland

${ }^{c}$ School of Pharmacy, University College Cork, Cork, Ireland required. The literature contains many such examples including protic acids, Lewis acids, organic bases and enzymes as well as catalyst-free methodologies. These conditions are generally mild, allowing for transformations with broad functional group tolerance. In the case of acid-catalysed transesterifications, anhydrous conditions are usually required to prevent hydrolysis. Current trends in this area seek to exploit the advantages of both heterogeneous and homogeneous catalysts to achieve superior yields with good selectivity and, critically for industry, reduced environmental impact.

Transesterification has been the subject of much study since the publication of Otera's comprehensive review. ${ }^{11}$ There has not been a similar exercise in the interim period of 1993-2021, so it is timely to conduct a fresh survey of the literature. This<smiles>CC[C@H](C)[C@H](OC(=O)CC(=O)O[C@H](Cc1ccccc1)OC(=O)[C@H](C)OC(=O)[C@H](NC(=O)[O-])C(=O)O)C(=O)O</smiles>

Prunustatin A (1)

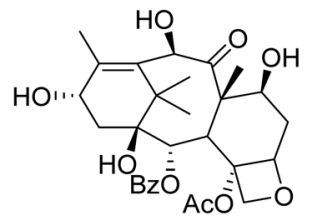

10-Deacetyl baccatin III (3)

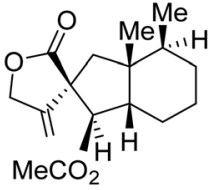

( \pm )-9-Acetoxyfukinanolide (2)

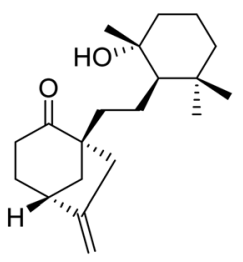

( \pm )-Velloziolone (4)
Fig. 1 Examples of products synthesized via the transesterification of $\beta$-keto esters. 


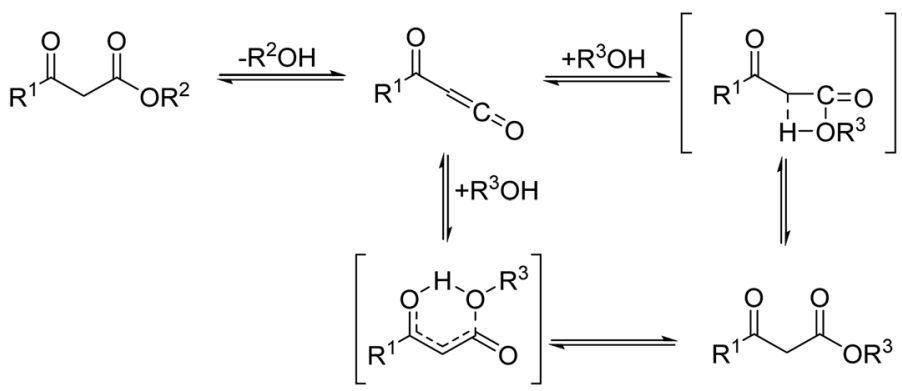

Scheme 1 Transesterification via an acylketene intermediate.

current review has been subdivided based on the different catalytic approaches as follows:

(1) Boron catalysts

(2) Amine catalysts

(3) Lipase catalysts

(4) Non-lanthanide metal catalysts

(5) Lanthanide catalysts

(6) Clay catalysts

(7) Mesoporous and microporous material-based catalysts

(8) Catalyst-free methodologies

(9) Miscellaneous methods

\section{Boron catalysts}

With increasing demand for environmentally sustainable reagents and greater regulatory constraints on the chemical industry, boronic acids are an attractive option for large scale synthesis as they display low toxicity and decompose into boric acid. Boronic acids are efficient Lewis acid catalysts due to their vacant $\mathrm{p}$ orbital in the $\mathrm{sp}^{2}$ hybridised boron atom which can form reversible covalent bonds with carbonyl and hydroxyl groups. ${ }^{13}$

Boric acid is an environmentally benign catalyst which has been successfully utilised in several transformations. ${ }^{14}$ Kondaiah et al. have described its application in the transesterification of ethyl acetoacetate with a variety of primary and secondary alcohols (Table 1 ). ${ }^{\mathbf{1 5}}$ The synthesis of $\beta$-keto esters using allylic (entry 9) and propargylic (entry 8) alcohols was successful with high yields obtained in a reaction time of just five hours. Tertiary alcohols were not compatible with these conditions.

Wankhede and co-workers have reported a mild and environmentally benign protocol for the transesterification of $\beta$-keto ethylesters by employing methylboronic acid. ${ }^{\mathbf{1 6}} 4 \AA$ molecular sieves were also used to remove the liberated ethanol and help drive the reaction to completion. Methylboronic acid could be recovered by simple filtration and reused up to three times without significant loss of yield. Primary alcohols (Table 2 entries 1-3, 7-10), secondary alcohols (entries 4 and 6), and tertiary alcohols (entry 5 ) are compatible with this methodology generating the corresponding transesterified products in moderate to high yields. For benzylic alcohols, the nature of the ring substituents was important, with electron-donating substituents increasing reactivity (entries 3 and 9) and electron-withdrawing substituents decreasing reactivity (entry 10). Transesterification with $\alpha, \beta$-unsaturated alcohols, such as cinnamyl alcohol (entries 7 and 8), is often challenging due to the propensity for Carroll rearrangement and subsequent decarboxylation (Scheme 2), ${ }^{\mathbf{1 7 - 2 0}}$ so the ability of this catalyst to facilitate the transformation of these particular substrates is significant. Other types of esters, such as $\alpha$-keto esters, $\gamma$-keto esters and simple esters, failed to react under these conditions.

Table 1 Boronic acid catalysis ${ }^{15}$

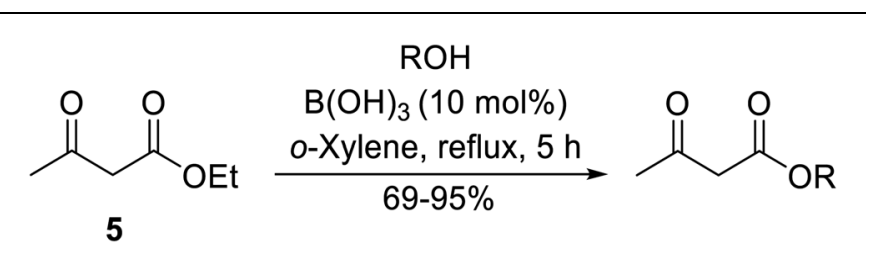

\begin{tabular}{|c|c|c|c|}
\hline Entry & $\mathrm{R}$ & Alcohol (equiv.) & Yield (\%) \\
\hline 1 & $\mathrm{Bn}$ & 1.5 & 75 \\
\hline 2 & ${ }^{n} \mathrm{Bu}$ & 2 & 92 \\
\hline 3 & $4-\mathrm{CF}_{3}-\mathrm{C}_{6} \mathrm{H}_{4} \mathrm{CH}_{2}$ & 1.5 & 95 \\
\hline 4 & ${ }^{\mathrm{i}} \mathrm{PrCH}_{2}$ & 2 & 82 \\
\hline 5 & ${ }^{t} \mathrm{BuCH}_{2}$ & 2 & 80 \\
\hline 6 & ${ }^{\mathrm{i}} \mathrm{Bu}$ & 2 & 72 \\
\hline 7 & & 2 & 72 \\
\hline 8 & $\mathrm{HC} \equiv \mathrm{CCH}_{2}$ & 2 & 71 \\
\hline 9 & $\mathrm{H}_{2} \mathrm{C}=\mathrm{CHCH}_{2}$ & 2 & 69 \\
\hline 10 & $\mathrm{Ph}\left(\mathrm{CH}_{2}\right)_{2}$ & 1.5 & 77 \\
\hline 11 & Menthyl & 1.5 & 92 \\
\hline 12 & Cy & 2 & 95 \\
\hline 13 & & 1.5 & 92 \\
\hline
\end{tabular}


Table 2 Transesterification with methylboronic acid ${ }^{16}$
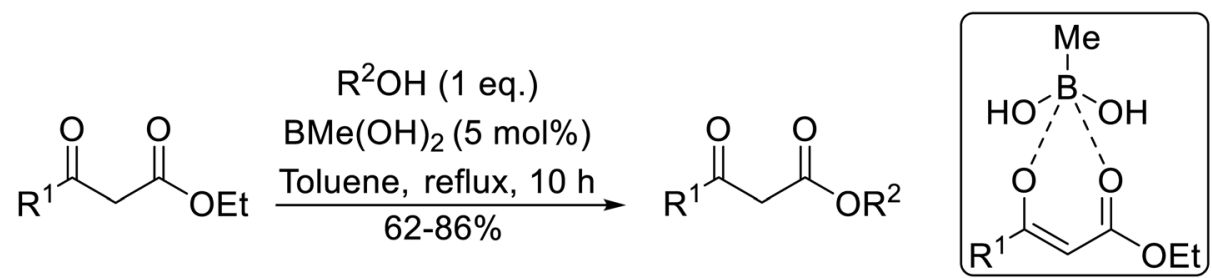

Coordination of boron

with $\beta$-keto ester carbonyls

\begin{tabular}{|c|c|c|c|}
\hline Entry & $\mathrm{R}^{1}$ & $\mathrm{R}^{2}$ & Yield (\%) \\
\hline 1 & Me & ${ }^{n}$ Dec & 86 \\
\hline 2 & Me & $\mathrm{Bn}$ & 75 \\
\hline 3 & Me & $4-\mathrm{MeO}-\mathrm{C}_{6} \mathrm{H}_{4} \mathrm{CH}_{2}$ & 81 \\
\hline 4 & $\mathrm{Me}$ & $(\mathrm{Ph})_{2} \mathrm{CH}$ & 73 \\
\hline 5 & Me & 1-Adamantanol & 76 \\
\hline 6 & Me & & 62 \\
\hline 7 & $\mathrm{Ph}$ & $\mathrm{PhCH}=\mathrm{CHCH}_{2}$ & 63 \\
\hline 8 & $\mathrm{Me}$ & $\mathrm{PhCH}=\mathrm{CHCH}_{2}$ & 81 \\
\hline 9 & Me & $4-\mathrm{Me}-\mathrm{C}_{6} \mathrm{H}_{4} \mathrm{CH}_{2}$ & 78 \\
\hline 10 & Me & $4-\mathrm{NO}_{2}-\mathrm{C}_{6} \mathrm{H}_{4} \mathrm{CH}_{2}$ & 69 \\
\hline
\end{tabular}

A likely explanation is that only $\beta$-keto esters allow for the formation of a 6-membered transition state by the coordination of boron with the two carbonyl oxygen atoms.

Arylboronic acids, particularly those with electron-withdrawing substituents on the aromatic ring, are often effective Lewis acid catalysts. For example, 3-nitrobenzeneboronic acid catalyses transesterifications in good to excellent yields with a $2.5 \mathrm{~mol} \%$ catalyst loading. ${ }^{21}$ Cyclic, aromatic and open-chain $\beta$-keto esters were successfully transesterified with primary, secondary, tertiary, cyclic, allylic and benzylic alcohols (Table 3). Other nucleophiles, including thiols and amines, were similarly compatible allowing for transthioesterification (entry 12) and transamidation<smiles>[R]C(=O)CCC=C</smiles>

Scheme 2 Carroll rearrangement and subsequent decarboxylation. respectively (entries 13 and 16). Amino alcohols reacted preferentially at the amine (entry 16) due to the increased nucleophilicity of the nitrogen, whereas mercapto alcohols reacted at the hydroxyl (entry 15). Interestingly, diols underwent exclusive monotransesterification (entry 14).

Liu and co-workers have exploited boron trifluoride diethyl etherate, a commercially available Lewis acid, for the transesterification of $\beta$-keto esters (Table 4). ${ }^{22}$ They also investigated other Lewis acid metal salts such as $\mathrm{NiCl}_{2}$, $\mathrm{CuCl}_{2}, \mathrm{Bi}\left(\mathrm{NO}_{3}\right)_{5}, \mathrm{Fe}_{2}\left(\mathrm{SO}_{4}\right)_{3}$ and $\mathrm{CoCl}_{2}$, but these returned lower yields. Methyl acetoacetate and phenyl acetoacetate reacted readily with aliphatic (entries 1-8, 14), aromatic (entries 10 and 11) and allyl (entry 9) alcohols in good to excellent yields. When $n$-butanol was utilised, aromatic $\beta$ keto esters (entry 14) were found to undergo transesterification faster than aliphatic $\beta$-keto esters (entry 1). Other esters, such as a simple aliphatic ester (entry 16), $\gamma$ ketoester (entry 17), nitrile ester (entry 18) or unsaturated esters (entries 19 and 20), failed to react under these conditions even with an extended reaction time of 8 hours.

Madje et al. have demonstrated how a combination of borate and zirconia may serve as a selective and inexpensive catalyst combination to effect transesterifications under solvent-free conditions (Table 5). ${ }^{23}$ Conversion of methyl/ethyl keto esters to higher homologues proceeded smoothly. The less reactive 
Table 3 Catalysis using 3-nitrobenzeneboronic acid ${ }^{21}$

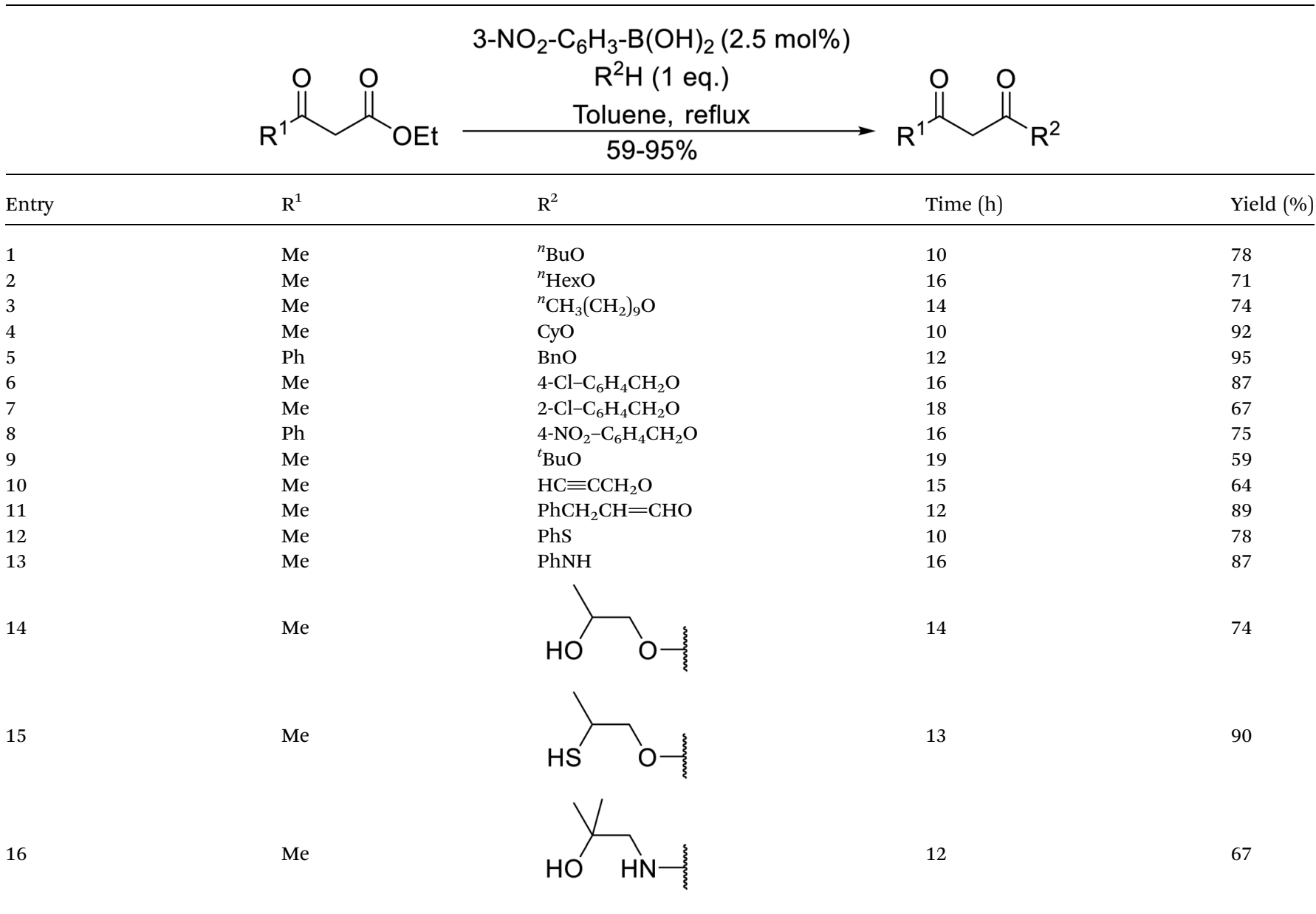

tert-butyl alcohol was converted to the corresponding $\beta$-keto ester in moderate yields (entry 2). Unsaturated alcohols (e.g., allyl alcohol) were also successfully transesterified (entry 3 ). The reaction was specific to $\beta$-keto esters as other esters, such as $\alpha$ keto esters and $\gamma$-keto esters, did not react. The catalyst was recovered and reused at least three times without any appreciable loss of activity (entry 6). Transesterification of methyl acetoacetate with cyclohexanol in the presence of sulfated zirconia was lower yielding than with borate/zirconia (entry 1). The authors suggest that the enhanced activity of $\mathrm{B}_{2} \mathrm{O}_{3} / \mathrm{ZrO}_{2}$ is due to the three-coordinated boron, which has an empty orbital and pulls the electron cloud onto the oxygen of $\mathrm{ZrO}_{2}$. The negative charge of boron is diffused into the $\mathrm{B}_{2} \mathrm{O}_{3}$ bulk via resonance between the lone pair of oxygen and the empty orbital of boron.

\section{Amine catalysts}

Amines are among some of the oldest reported transesterification catalysts. In recent years, there has been renewed interest in the development of heterogeneous amine catalysts that possess improved toxicity profiles and the potential to be recovered and reused.

The application of 4-DMAP as a catalyst for the transesterification of $\beta$-keto esters was first described by Taber et al. in 1985 (Table 6). ${ }^{24}$ Taber compared the use of an excess of either the alcohol (entry 4 ) or the $\beta$-keto ethyl ester (entry 3 ) with a $30 \mathrm{~mol} \%$ loading of 4-DMAP in an attempt to force the reactions to completion. Employing an excess of the ester was found to be more effective overall. Non-enolisable $\beta$-keto esters (entry 2 ) and tertiary alcohols (entry 5) were incompatible with these conditions.

Building upon Taber's methodology, Gilbert and Kelly reexamined the 4-DMAP-catalysed transesterification of allylic alcohols in the presence of $4 \AA$ molecular sieves. ${ }^{25}$ Good yields were recorded using stoichiometric amounts of the reagents and lower reaction temperatures (Table 7). Allyl alcohol (entries 1 and 6) furnished poor yields due to absorption into the molecular sieves. However, this problem was easily addressed by replacing the $4 \AA$ sieves with $3 \AA$ sieves (entry 2). Similar to Taber's findings, both tertiary alcohols and non-enolisable ketones proved unreactive. This may, in part, be due to 
Table 4 Boron trifluoride diethyl etherate catalysis ${ }^{22}$

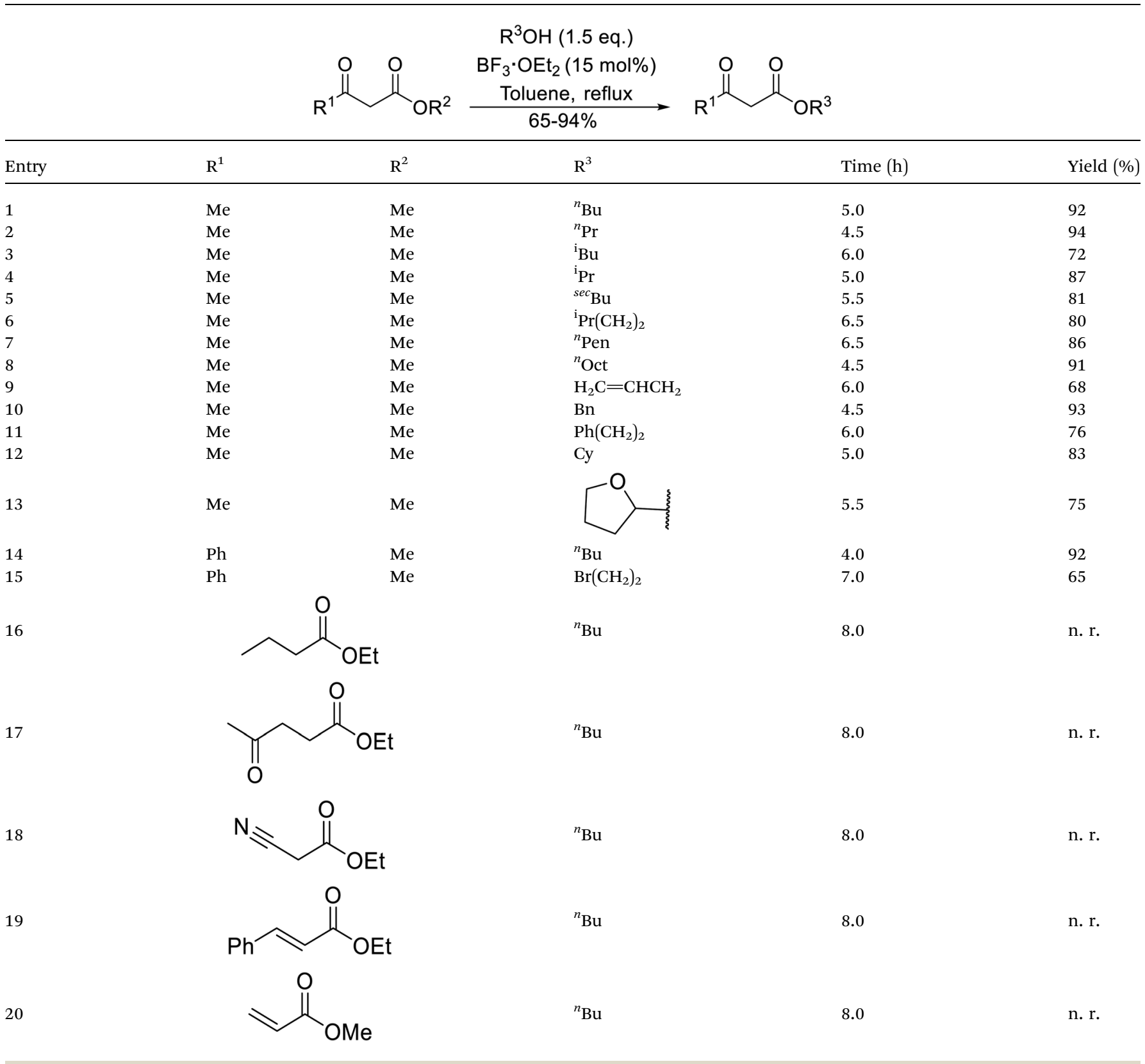

a steric effect as ethyl 2-methyl-3-oxobutanoate (entries 6-9) required a much longer reaction time of 36 hours than ethyl acetoacetate (entry 1).

Christoffers and Önal further improved upon Taber's methodology by replacing toluene with cyclohexane as the solvent. ${ }^{26}$ Importantly, these conversions proceeded with nearly stoichiometric amounts of starting materials and $5 \mathrm{~mol} \%$ of 4 DMAP (Table 8). The methanol liberated from the reaction forms an azeotrope with cyclohexane in the vapour phase, allowing for the methanol to be removed by azeotropic distillation. A challenging double transesterification involving 2.2 equivalents of menthol proceeded in high yields (entry 8). By contrast, sterically crowded $\beta$-keto esters (entries 5 and 6) afforded lower yields.

An interesting application of this approach is described by Shinoda and Osuka. They explored the chemoselective transesterification of the photosynthetic pigment, methyl pheophorbide- $\alpha$ (6), with complex alcohols (Table 9). ${ }^{27} \mathrm{~A}$ combination of 2-chloro-1-methylpyridinium iodide (CMPI) and 4-DMAP was a prerequisite for successful conversion. 4-DMAP could be substituted with other bases, such as trimethylamine, affording similar results. Of all the alcohols tested, sterols 
Table 5 Borate/zirconia-catalysed transesterification of methyl and ethyl $\beta$-keto esters ${ }^{23}$

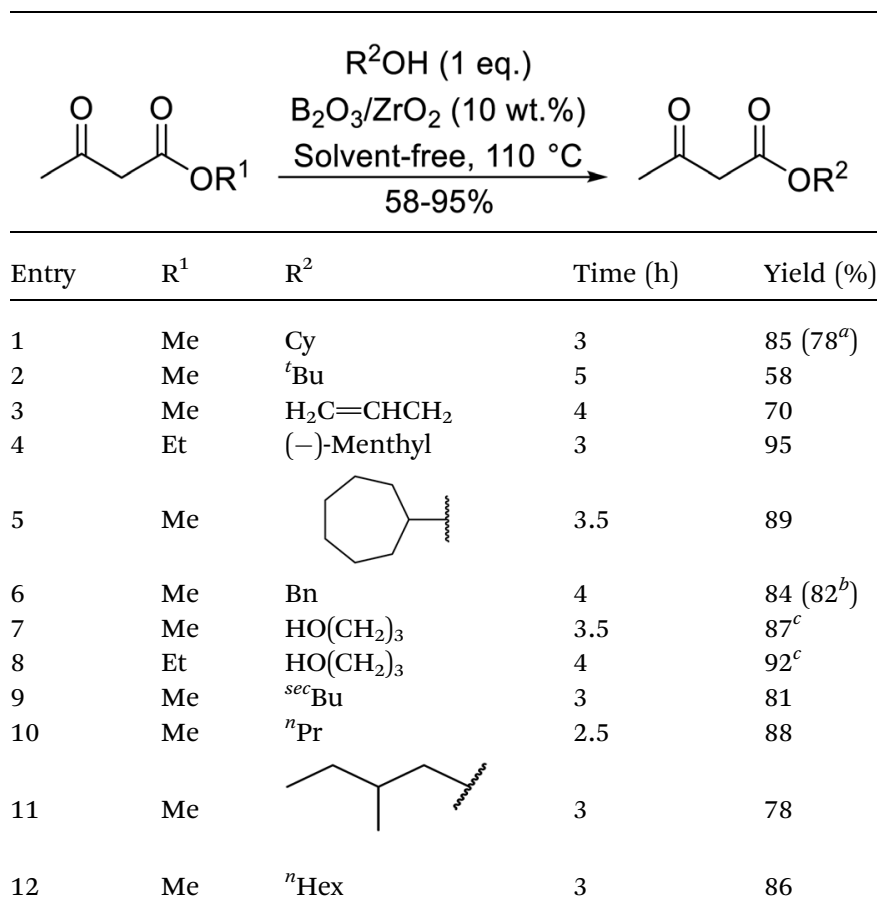

${ }^{a}$ Yield with sulfated zirconia. ${ }^{b}$ Yield after third cycle. ${ }^{c}$ Two equivalents of ester used.

Table 6 4-DMAP catalysis in toluene ${ }^{24}$

4-DMAP (30 mol\%)
$\frac{\mathrm{R}^{3} \mathrm{OH}}{\text { Toluene, reflux, 42 } \mathrm{h}}$
(3 eq.)

\begin{tabular}{|c|c|c|c|c|}
\hline Entry & $\mathrm{R}^{1}$ & $\mathrm{R}^{2}$ & $\mathrm{R}^{3}$ & Yield (\%) \\
\hline 1 & $\mathrm{Me}$ & $\mathrm{H}$ & (-)-Menthyl & 83 \\
\hline 2 & $\mathrm{Me}$ & $\left(\mathrm{H}_{2} \mathrm{C}=\mathrm{CH}\right)_{2}$ & (-)-Menthyl & n. $r$. \\
\hline 3 & ${ }^{n}$ Pen & $\mathrm{H}$ & ${ }^{n} \mathrm{Bu}$ & $74^{a}$ \\
\hline 4 & ${ }^{n}$ Pen & $\mathrm{H}$ & ${ }^{n} \mathrm{Bu}$ & $41^{b}$ \\
\hline 5 & ${ }^{n}$ Pen & $\mathrm{H}$ & ${ }^{t} \mathrm{Bu}$ & n. $r$. \\
\hline 6 & $\mathrm{Me}$ & $\mathrm{H}$ & & 71 \\
\hline 7 & $\mathrm{Me}$ & $\mathrm{Me}$ & & 55 \\
\hline
\end{tabular}

${ }^{a}$ Excess ester. ${ }^{b}$ Excess alcohol.
Table 7 Catalysis using 4-DMAP and $4 \AA$ molecular sieves ${ }^{25}$

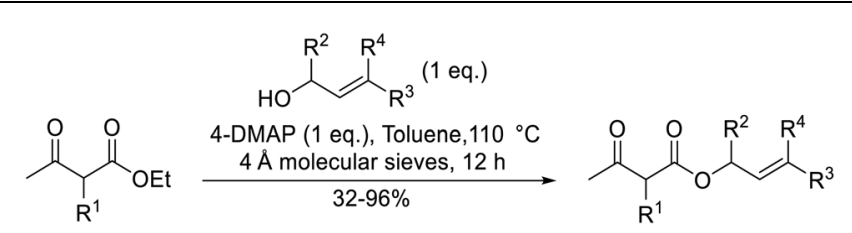

\begin{tabular}{llllll}
\hline Entry & $\mathrm{R}^{1}$ & $\mathrm{R}^{2}$ & $\mathrm{R}^{3}$ & $\mathrm{R}^{4}$ & Yield (\%) \\
\hline 1 & $\mathrm{H}$ & $\mathrm{H}$ & $\mathrm{H}$ & $\mathrm{H}$ & 45 \\
2 & $\mathrm{H}$ & $\mathrm{H}$ & $\mathrm{H}$ & $\mathrm{H}$ & $96^{a}$ \\
3 & $\mathrm{H}$ & $\mathrm{H}$ & $\mathrm{Me}$ & $\mathrm{H}$ & 94 \\
4 & $\mathrm{H}$ & $\mathrm{H}$ & $\mathrm{Me}$ & $\mathrm{Me}$ & 86 \\
5 & $\mathrm{H}$ & $\mathrm{Me}$ & $\mathrm{H}$ & $\mathrm{H}$ & 84 \\
6 & $\mathrm{Me}$ & $\mathrm{H}$ & $\mathrm{H}$ & $\mathrm{H}$ & $32^{b}$ \\
7 & $\mathrm{Me}$ & $\mathrm{H}$ & $\mathrm{Me}$ & $\mathrm{H}$ & $83^{b}$ \\
8 & $\mathrm{Me}$ & $\mathrm{H}$ & $\mathrm{Me}$ & $\mathrm{Me}$ & $84^{b}$ \\
9 & $\mathrm{Me}$ & $\mathrm{Me}$ & $\mathrm{H}$ & $\mathrm{H}$ & $54^{b}$
\end{tabular}

${ }^{a} 3 \AA$ molecular sieves, 36 hours reaction time. ${ }^{b} 36$ hours reaction time.

exhibited the highest reactivity (entries 1 and 2). Esterification of ethylene glycol proceeded at both hydroxyls to generate a pheophorbide dimer (entry 5).

4-DMAP-catalysed reactions of $\beta$-keto esters with cyclic and acyclic Baylis-Hillman alcohols produced the C-allylation adduct exclusively, rather than the expected transesterification or Carroll rearrangement products (Scheme 3). ${ }^{28,29}$ This unexpected outcome is likely due to the presence of an electronwithdrawing group on the activated alkene, which appears to be essential for this transformation. The authors suggest that the mechanism involves conjugate addition of 4-DMAP to the Michael acceptor, followed by the elimination of water to afford an enone intermediate. Subsequent conjugate addition of a $\beta$ dicarbonyl enolate and elimination of 4-DMAP provides the final C-allylation product. The overall reaction may be described as a palladium-free Tsuji-Trost-type process.

2,6-Lutidine is a weakly nucleophilic base owing to the steric effect of the two methyl groups on the pyridine ring. Lutidine is a suitable replacement for 4-DMAP in the transesterification of ethyl acetoacetate with Baylis-Hillman alcohols, affording exclusively the desired allylic ester in good yields (Table 10). ${ }^{28}$ No evidence of Carroll decarboxylative rearrangement ketones or C-allylation products was observed.

The replacement of 2,6-lutidine with triethylamine resulted in a mixture of transesterified and C-alkylated adducts as noted by Mhasni and Rezgui (Scheme 4).$^{28}$ The formation of the minor allylation product was attributed to the lower nucleophilicity of triethylamine which may have instead behaved as a Brønsted base. The use of 4-DMAP in place of triethylamine saw the selective formation of the C-allylation product in a $58 \%$ yield.

Triethylamine-catalysed transesterification of a range of $\beta$ keto esters with Baylis-Hillman alcohols was subsequently 
Table 8 4-DMAP catalysis in cyclohexane ${ }^{26}$

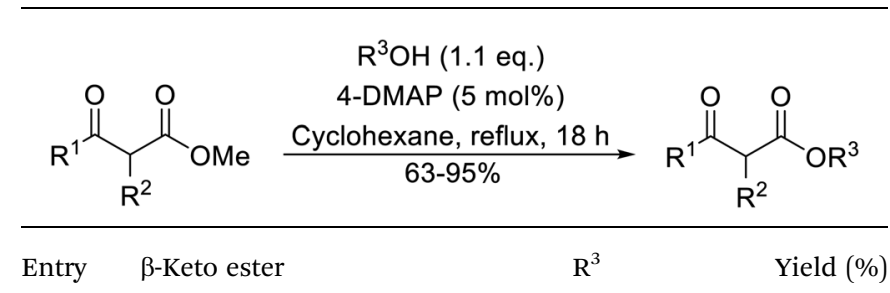

1<smiles>COC(=O)C1CCCC1=O</smiles><smiles>COC(=O)C1CCCC1=O</smiles>

(-)-Menthyl 95

2

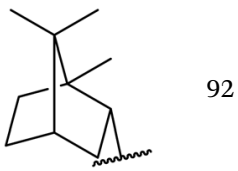

3<smiles>COC(=O)C1CCCC1=O</smiles><smiles>CC(C)C(C)c1ccccc1</smiles>

4<smiles>COC(=O)C1CCCC1=O</smiles>

Bn

5<smiles>COC(=O)C1CCc2ccccc2C1=O</smiles>

(-)-Menthyl<smiles>COC(=O)C1CCc2ccccc2C1=O</smiles><smiles>CC(C)C(C)c1ccccc1</smiles>

(-)-Menthyl $\quad 92^{a}$

8<smiles>COC(=O)CC(=O)CC(=O)OC</smiles><smiles>CC1C2CCC(C)(C1C)C2(C)C</smiles>

${ }^{a}$ Di-transesterification product.

investigated (Table 11). Interestingly, when two possible sites for transesterification were present in the substrate, as with diethyl malonate, only mono-transesterification was observed (entries 4 and 9). When less than two equivalents of triethylamine were employed, the reaction did not reach completion, even after a prolonged reaction time of 72 hours.

Further investigations by the same group encompassed a range of allyl (Table 12, entries 1-5), benzyl (entry 6), propargyl

(entry 7), and alkyl (entries 8-12) alcohols. ${ }^{30}$ The reactions reached completion within 3-27 hours, affording the target esters in good yields. Carroll decarboxylative rearrangement or C-allylation products were not observed.

Palaniappan and Shekhar have reported the replacement of conventional amine catalysts with eco-friendly polyaniline salts including polyaniline-sulfate, polyaniline-nitrate and polyanilinehydrochloride (Table 13). ${ }^{31}$ Polyaniline is a para-linked phenylene amineimine as described by the general formula in Fig. 2. Polyaniline sulfate was more efficient than polyaniline nitrate, which in turn was found to be more efficient than polyaniline hydrochloride. Yields with aliphatic alcohols were excellent, generally reaching over 90\% (entries 1-8). Propargyl alcohols reacted smoothly (entry 11) while allylic alcohol proved more problematic with only a $23 \%$ yield recorded (entry 15). Some of the advantages of polyaniline salt catalysts include their easy preparation, improved recovery and reusability, and low toxicity. The salts were recovered and reused three times, with no significant loss of yield noted.

Hagiwara et al. have demonstrated the $N$-methylaminopropylated silica (NMAP) catalysed self-condensation of aldehydes. ${ }^{32,33}$ The same group found that $N, N$-diethylaminopropylated silica (NDEAP) efficiently catalysed the transesterification of $\beta$-keto esters (Table 14). ${ }^{34}$ Distribution of the $N, N$-diethylamino residue over the wide surface area of the silica gel allows for a high turnover number (TON) of 425 and a turnover factor (TOF) of 170 . Alcohols containing acid-sensitive or base-sensitive substituents were converted in excellent yields (entries 4-6), highlighting the mild nature of this protocol. Substrates bearing an olefinic moiety, which would normally be sensitive to metal-based catalysis, were converted to the transesterified product in good yields (entry 2). C-2-substituted $\beta$ keto esters were similarly compatible (entry 11). 2-(4-Hydroxyphenyl) ethyl alcohol was observed to react exclusively at the primary alcohol group, facilitating a regioselective transformation (entry 16). The catalyst could be reused five times without requiring re-activation.

When the transesterification of keto esters 12 and 13 with menthol was attempted under these conditions, only starting material was recovered (Fig. 3). The transesterification of methyl $\alpha$-phenylsulfinylacetate (14) and methyl diethylphosphonoacetate (15) was similarly unsuccessful. The requirement for acidic $\alpha$-protons would suggest that this transformation proceeds via a ketene intermediate.

Hexamethylenetetramine (HMT) has been identified by Ribeiro and co-workers as an efficient transesterification catalyst (Table 15). ${ }^{35}$ HMT is an inexpensive, non-hygroscopic, and stable reagent with low toxicity ${ }^{36}$ Four different methods were compared utilising different combinations of solvents, substrate loadings or the use of a Dean-Stark trap (Table 15). In general, method $\mathrm{C}$ was found to be the most effective. Transesterification of an $\alpha$-substituted acetoacetate with tert-butyl alcohol returned low yields (entry 14), which can be attributed to the bulky nature of the substrate. Introduction of $\alpha, \alpha$-disubstituted $\beta$-keto esters resulted in recovery of starting material only, suggesting reaction via a ketene intermediate (entries 15 and 16). Other esters, such as ethyl phenylacetate (entries 18 and 19) or the triglyceride trimyristin (entry 20), proved incompatible. 
Table 9 4-DMAP and CMPI catalysis ${ }^{27}$

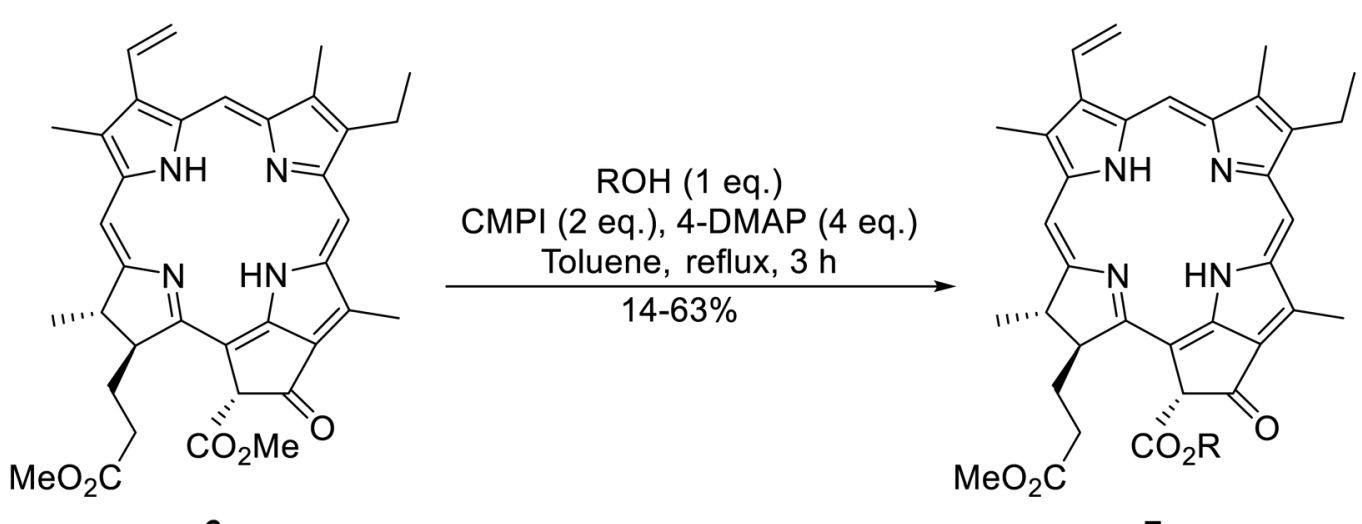

Entry

$\mathrm{R}$

Yield (\%)

1

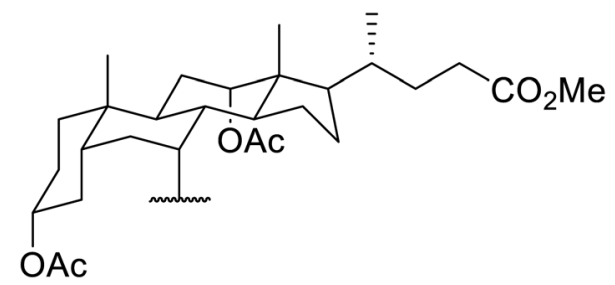

2

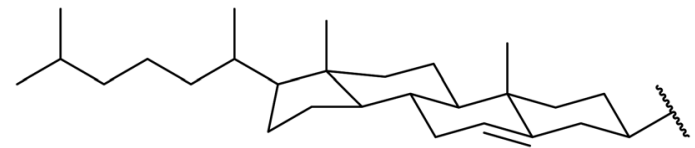

57

${ }^{n} \mathrm{CH}_{3}\left(\mathrm{CH}_{2}\right)_{17}$

$\mathrm{HO}\left(\mathrm{CH}_{2}\right)_{2}-$

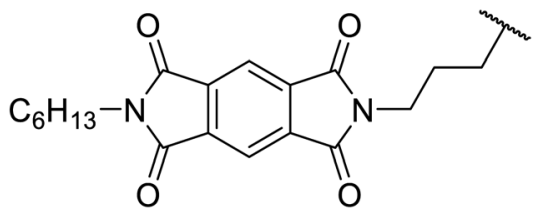

41

38
$14^{a}$

6<smiles></smiles>

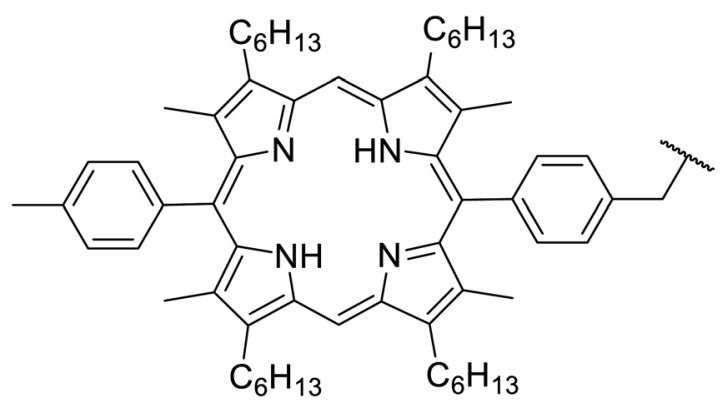

\footnotetext{
${ }^{a}$ Pheophorbide dimer.
} 
<smiles>O=C1CCCC=C1CO</smiles>
1) 1,4-addition<smiles>[R]C(=O)C(CC1=CCCCC1=O)C([R])=O</smiles>

Scheme 3 Mechanism of DMAP-catalysed C-allylations. ${ }^{29}$

Table $10 \quad 2,6$-Lutidine-catalysed transesterification ${ }^{28}$

Entry

\section{Lipase catalysts}

Conventional transesterification catalysts often require high reaction temperatures. By contrast, lipase-mediated reactions are possible at lower temperatures and do not require organic solvents. Lipases are a class of serine hydrolases which catalyse a range of reactions including ester hydrolysis, esterification and interesterification (ester and acid). ${ }^{37,38}$ Furthermore, these enzymes can typically be recovered and reused.

Córdova and Janda published the first general route for a lipase-catalysed transesterification of $\beta$-keto esters (Table 16). ${ }^{39}$ Candida antarctica lipase B (CALB) was immobilized on a microporous resin allowing the lipase to be recycled without loss of activity. Both primary alcohols (entries 1-6 and 9-12) and secondary alcohols (entries 7 and 8) were compatible substrates, as were allylic alcohols (entries 2, 3, 7, 9 and 11) and propargylic alcohols (entries 4 and 10). CALB also efficiently acetylated the polymer poly(ethylene glycol) monomethyl ether (MeO-PEG5000) (entry 6), which could be used in a polymersupported synthesis of interesting heterocycles. CALB was found to be selective for aliphatic alcohols over phenols (entry $8)$. One potential drawback of this methodology is the requirement for a large excess of the $\beta$-keto ester.

The same group applied this methodology to the resolution of secondary alcohols via their enantioselective transesterification with methyl acetoacetate (Table 17). ${ }^{39}$ Good yields and excellent stereoselectivities were observed with CALB.

Various lipases have been screened by Yadav and Lathi for the transesterification of methyl acetoacetate with $n$-butanol. ${ }^{\mathbf{4 0}}$ Of the three biocatalysts studied, namely Novozym 435 (Candida antarctica), Lipozyme RM IM (Mucor miehei) and Lipozyme TL IM (Thermomyces lanuginosus), Novozym 435 was the most effective at 3\% enzyme loading. Yadav and Lathi subsequently developed a novel methodology combining enzyme and microwave catalysis (Table 18). ${ }^{41}$ Microwave-mediated

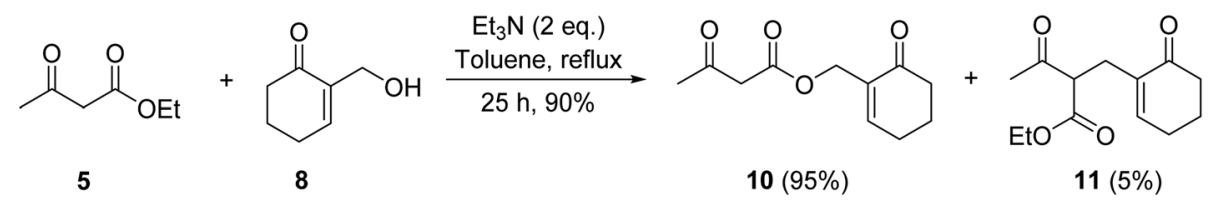

Scheme 4 Triethylamine-mediated transesterification of ethyl acetoacetate with Baylis-Hillman alcohol. ${ }^{28}$ 
Table 11 Triethylamine as a catalyst for the transesterification of Baylis-Hillman alcohols ${ }^{28}$

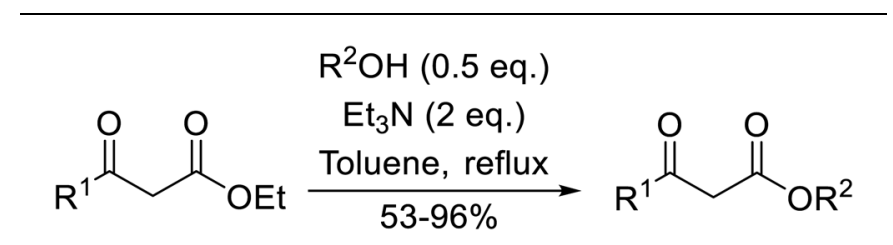

\begin{tabular}{|c|c|c|c|c|}
\hline Entry & $\mathrm{R}^{1}$ & $\mathrm{R}^{2}$ & Time (h) & Yield (\%) \\
\hline
\end{tabular}

$\mathrm{Ph}$<smiles>CC(C)CC1=CCCCC1=O</smiles>

24

$1 \quad \mathrm{Ph}$<smiles>CCOC(=O)C1CCCC1=O</smiles><smiles>CC(C)CC1=CCCCC1=O</smiles>

24<smiles>CCOC(=O)C1CCCCC1=O</smiles><smiles>CC(C)CC1=CCCCC1=O</smiles>

24

54

85

3

$4 \quad$ EtO

$5 \quad \mathrm{Me}$

$6 \quad \mathrm{Ph}$

$7 \quad \mathrm{Me}$

8

$\mathrm{Ph}$<smiles>CC(C)CC1=CCCCC1=O</smiles>

48<smiles>CC(C)C(C)C1=CCCCC1=O</smiles>

48<smiles>CC(C)C(C)C1=CCCCC1=O</smiles>

24<smiles>CCCC(C1=CCCCC1=O)C(C)C</smiles>

29<smiles>CCCC(C1=CCCCC1=O)C(C)C</smiles>

24<smiles>CC(C)CC1=CCCC1=O</smiles>

76

72

96

89

90

53
$9 \quad$ EtO
Table 11

(Contd.)

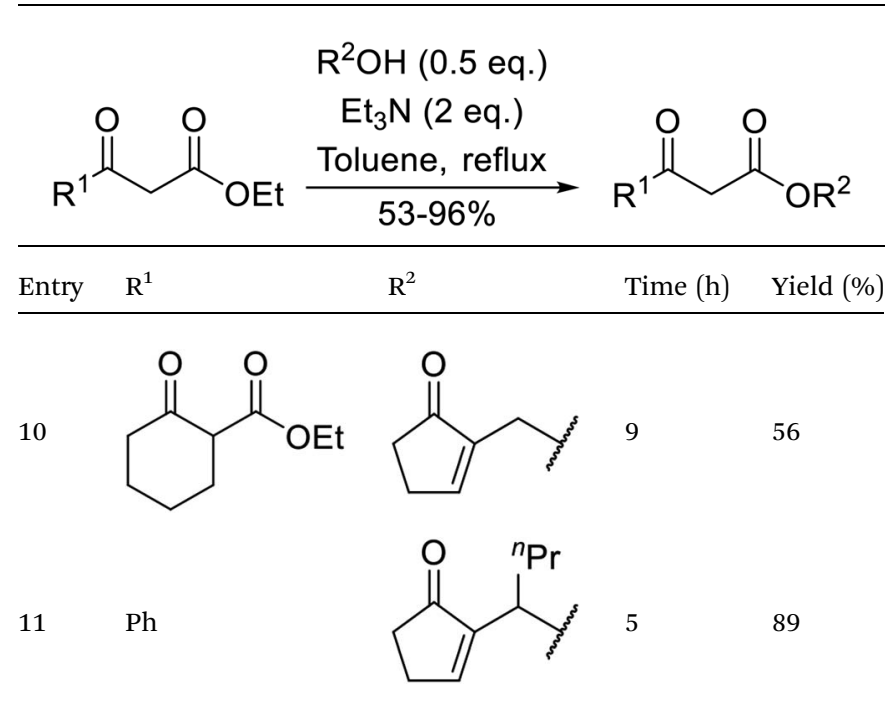

Table 12 Triethylamine-mediated transesterification of various alcohols ${ }^{30}$

90

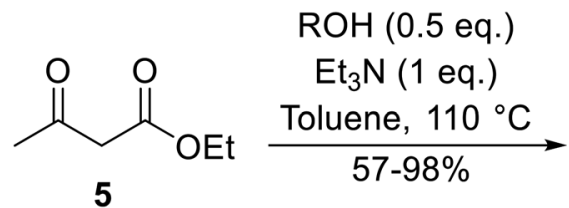<smiles>[R]OC(=O)CC(C)=O</smiles>

\begin{tabular}{|c|c|c|c|}
\hline Entry & $\mathrm{R}$ & Time (h) & Yield (\%) \\
\hline 1 & $\mathrm{PhCH}=\mathrm{CHCH}_{2}$ & 5 & 95 \\
\hline 2 & $\mathrm{CH}_{3} \mathrm{CH}=\mathrm{CHCH}_{2}$ & 10 & 91 \\
\hline 3 & $\mathrm{H}_{2} \mathrm{C}=\mathrm{C}\left(\mathrm{CH}_{3}\right) \mathrm{CH}_{2}$ & 5 & 87 \\
\hline 4 & $\mathrm{H}_{2} \mathrm{C}=\mathrm{CHCH}\left(\mathrm{CH}_{3}\right)$ & 6 & 82 \\
\hline 5 & $\mathrm{H}_{2} \mathrm{C}=\mathrm{CHC}\left(\mathrm{CH}_{3}\right)_{2}$ & 24 & 57 \\
\hline 6 & $\mathrm{Bn}$ & 3 & 72 \\
\hline 7 & $\mathrm{HC} \equiv \mathrm{CCH}_{2}$ & 7 & 78 \\
\hline 8 & $\left(\mathrm{CH}_{3}\right)_{2} \mathrm{CHCH}_{2}$ & 25 & 74 \\
\hline 9 & ${ }^{n} \mathrm{Bu}$ & 27 & 80 \\
\hline 10 & ${ }^{n} \mathrm{CH}_{3}\left(\mathrm{CH}_{2}\right)_{9}$ & 22 & 97 \\
\hline 11 & $\mathrm{Cy}$ & 8 & 84 \\
\hline 12 & Menthyl & 21 & 98 \\
\hline
\end{tabular}

transesterifications were significantly faster than conventional heating. The same three enzymes were compared and Novozyme was again found to be superior. Both primary (entries 1-6) and secondary alcohols (entries 7-9) were examined and in both cases, increased chain length led to decreased conversions. The lipase could be reused with negligible loss of activity, confirming that microwave irradiation does not deactivate the enzyme. 
Table 13 Polyaniline salt catalysis ${ }^{31}$

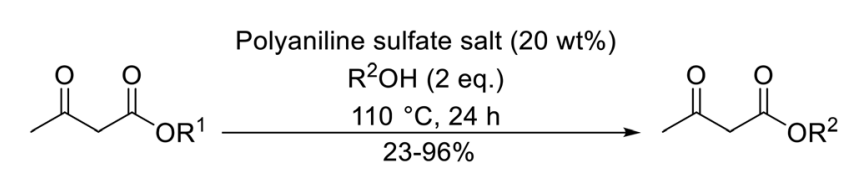

\begin{tabular}{|c|c|c|c|}
\hline Entry & $\mathrm{R}^{1}$ & $\mathrm{R}^{2}$ & Yield (\%) \\
\hline 1 & $\mathrm{Et}$ & ${ }^{n}$ Hex & 96 \\
\hline 2 & $\mathrm{Me}$ & ${ }^{n}$ Hex & 96 \\
\hline 3 & $\mathrm{Ph}$ & ${ }^{n}$ Hex & 90 \\
\hline 4 & Et & ${ }^{n} \mathrm{Bu}$ & 94 \\
\hline 5 & Et & ${ }^{n}$ Oct & 94 \\
\hline 6 & Et & ${ }^{n} \mathrm{CH}_{3}\left(\mathrm{CH}_{2}\right)_{9}$ & 90 \\
\hline 7 & Et & ${ }^{n} \mathrm{CH}_{3}\left(\mathrm{CH}_{2}\right)_{11}$ & 92 \\
\hline 8 & Et & ${ }^{n} \mathrm{CH}_{3}\left(\mathrm{CH}_{2}\right)_{21}$ & 94 \\
\hline 9 & Et & $\operatorname{EtO}\left(\mathrm{CH}_{2}\right)_{2}$ & 96 \\
\hline 10 & Et & ${ }^{n} \mathrm{BuO}\left(\mathrm{CH}_{2}\right)_{2}$ & 96 \\
\hline 11 & Et & $\mathrm{HC} \equiv \mathrm{C}\left(\mathrm{CH}_{2}\right)_{2}$ & 90 \\
\hline 12 & $\mathrm{Et}$ & Menthyl & 94 \\
\hline 13 & Et & Cy & 85 \\
\hline 14 & Et & $\mathrm{Bn}$ & 72 \\
\hline 15 & Et & $\mathrm{H}_{2} \mathrm{C}=\mathrm{CHCH}_{2}$ & 23 \\
\hline
\end{tabular}

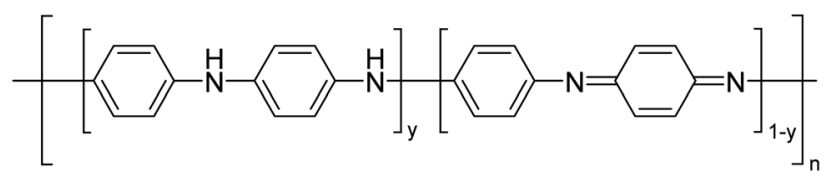

Fig. 2 General formula for polyaniline salt.

A synergistic combination of enzymes produced good to excellent yields of transesterified $\beta$-keto esters in research conducted by Wiśniewska and colleagues. ${ }^{42}$ The enzymes CALB (Novozym 435) from Candida antarctica, Novozyme proteases from Carica papaya, lipase from Rhizopus niveus and lipoprotein lipase from Pseudomonas sp., afforded higher yields in combination than individually (Table 19). In the case of 1-phenylethanol, a slightly higher yield was obtained with ethyl acetoacetate (entry 5) than for tert-butyl acetoacetate (entry 6). Conversely, for aromatic alcohols containing electronwithdrawing groups, the yields produced were higher for tertbutylacetoacetate (entries 8 and 10) than ethyl acetoacetate (entries 7 and 9).

\section{Non-lanthanide metal catalysts}

\subsection{Transition metals}

Reddy et al. have described the application of molybdenumzirconium oxide $\left(\mathrm{Mo}-\mathrm{ZrO}_{2}\right)$ as a solid superacid catalyst (Table 20). ${ }^{43}$ The high acidity of $\mathrm{Mo}-\mathrm{ZrO}_{2}$ is due to its electron deficient state resulting from the introduction of Mo-cations into the $\mathrm{ZrO}_{2}$ solid lattice. The wet catalyst was found to be recyclable after a simple filtration with no loss of activity. Neither tertbutanol (entry 3) nor phenol (entry 9) proved suitable substrates. However, other aromatic alcohols were compatible (entry 10). Secondary alcohols (entries 2, 5 and 7) and long chain primary alcohols (entries 4 and 6) produced relatively low yields. A notable exception to this trend was cyclohexanol which returned a high $97 \%$ yield (entry 11 ).

Niobium oxide is a proven catalyst for esterification, ${ }^{44,45}$ hydration, ${ }^{46}$ oxidation $^{47}$ and acylation ${ }^{48}$ reactions. Donate and co-workers recently reported the use of niobium oxide for the rapid transesterification of $\beta$-keto esters with a range of alcohols (Table 21). ${ }^{49}$ Full conversion was only achieved with $n$-butanol (entry 7). Primary alcohols (entries 1-7, 10) afforded superior conversions and yields compared to secondary (entries 9 and 11) or tertiary alcohols (entries 8). Less than $50 \%$ conversion was recorded when benzyl alcohol was introduced (entry 10), possibly due to concomitant dehydration and the formation of benzyl ether. As volatile alcohols may be prone to evaporation, gradual addition of the alcohols significantly increased substrate conversion in these cases. The catalyst may be reused three times without loss of activity.

$\left[N, N^{\prime}\right.$-Ethylene $\quad$ bis(salicylideneaminato)]manganese(III) chloride (Mn(III) salen complex) has been successfully utilized in Knoevenagel condensations. ${ }^{50}$ Similarly, vanadyl(Iv) acetate has been found to be effective for the catalysis of acetylations. ${ }^{51}$ These catalysts are also useful in the transesterification of $\beta$-keto esters (Table 22). ${ }^{52}$ The reactions proceeded cleanly with no byproduct isolated. $\mathrm{Mn}$ (III) salen consistently outperformed the vanadyl(Iv) acetate complex, affording higher yields and slightly shorter reaction times, at a lower catalyst loading of $7 \mathrm{~mol} \%$ compared to $13.5 \mathrm{~mol} \%$ of vanadyl(Iv) acetate. With this catalyst system, unsaturated alcohols such as propargyl (entry 1), crotyl (entry 4) and cinnamyl alcohol (entry 7) were readily transformed affording esters in high yields. By contrast, tertiary alcohols (entry 10) failed to react in the presence of vanadyl(Iv) acetate. Aryl alcohols (entries 7, 8 and 9), cyclic alcohols (entries 2 and 6) and long chain primary alcohols (entries 3 and 11) were converted to the corresponding esters in high yields. When the ambident substrate 2-amino-1-butanol was tested (entry 15), successful transesterification via the hydroxyl was observed while the amine group remained intact. Both catalysts were recyclable up to five times without any significant loss in activity.

Li et al. investigated the utility of manganese chloride (Table 23). ${ }^{53} \mathrm{MnCl}_{2} \cdot 4 \mathrm{H}_{2} \mathrm{O}$ catalysed the reaction of $N$-(2-hydroxy)ethylindole and sterically challenging tert-butyl acetoacetate in a $90 \%$ yield (entry 6). Anhydrous $\mathrm{MnCl}_{2}$ also performed well, but a slightly poorer yield of $80 \%$ was recorded. Interestingly, addition of 0.4 equivalents of water afforded yields comparable to that of $\mathrm{MnCl}_{2} \cdot 4 \mathrm{H}_{2} \mathrm{O}$. During the reaction, both anhydrous $\mathrm{MnCl}_{2}$ and $\mathrm{MnCl}_{2} \cdot 4 \mathrm{H}_{2} \mathrm{O}$ were fully soluble in toluene, indicating that solubility does not account for the difference in activity. The authors suggest that a small amount of water might play a role in tuning the acidity of the manganese catalyst.

Krasik has demonstrated how titanium ethoxide may be employed to catalyse the transesterification of the sterically 


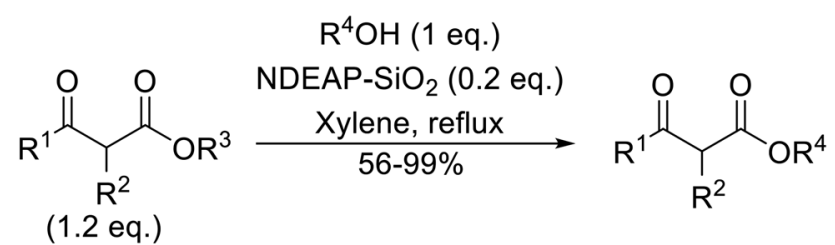

\begin{tabular}{|c|c|c|c|c|c|c|}
\hline Entry & $\mathrm{R}^{1}$ & $\mathrm{R}^{2}$ & $\mathrm{R}^{3}$ & $\mathrm{R}^{4}$ & Time (h) & Yield (\%) \\
\hline 1 & Me & $\mathrm{H}$ & Me & $\mathrm{Ph}\left(\mathrm{CH}_{2}\right)_{2}$ & 24 & 56 \\
\hline 2 & Me & $\mathrm{H}$ & Me & & 24 & 70 \\
\hline 3 & Me & $\mathrm{H}$ & Me & $\mathrm{PhCH}_{2}$ & 5.5 & 75 \\
\hline 4 & $\mathrm{Me}$ & $\mathrm{H}$ & $\mathrm{Me}$ & $\mathrm{AcO}\left(\mathrm{CH}_{2}\right)_{5}$ & 4 & 84 \\
\hline 5 & Me & $\mathrm{H}$ & Me & & 2 & 88 \\
\hline 6 & Me & $\mathrm{H}$ & Me & & 2 & 85 \\
\hline 7 & Me & $\mathrm{H}$ & Me & Cholester & 24 & 89 \\
\hline 8 & Me & $\mathrm{H}$ & Me & & 21 & 72 \\
\hline 9 & Me & $\mathrm{H}$ & Me & Menth & 7 & 99 \\
\hline 10 & Me & $\mathrm{H}$ & ${ }^{t} \mathrm{Bu}$ & Menth & 0.5 & 82 \\
\hline 11 & Me & $\mathrm{Bn}$ & Me & Menth & 8.5 & 76 \\
\hline 12 & Me & $\mathrm{H}$ & Me & & 6.5 & 97 \\
\hline 13 & $\mathrm{Me}$ & $\mathrm{H}$ & Me & Terpine & 3.5 & 78 \\
\hline 14 & & & & $\mathrm{Ph}\left(\mathrm{CH}_{2}\right)_{2}$ & 7 & 95 \\
\hline 15 & & & & & 3.5 & 91 \\
\hline 16 & & & & $\mathrm{HOC}_{6} \mathrm{H}_{4}\left(\mathrm{CH}_{2}\right)_{2}$ & 3 & 99 \\
\hline 17 & & & & $\operatorname{AcO}\left(\mathrm{CH}_{2}\right)_{6}$ & 4 & 84 \\
\hline
\end{tabular}




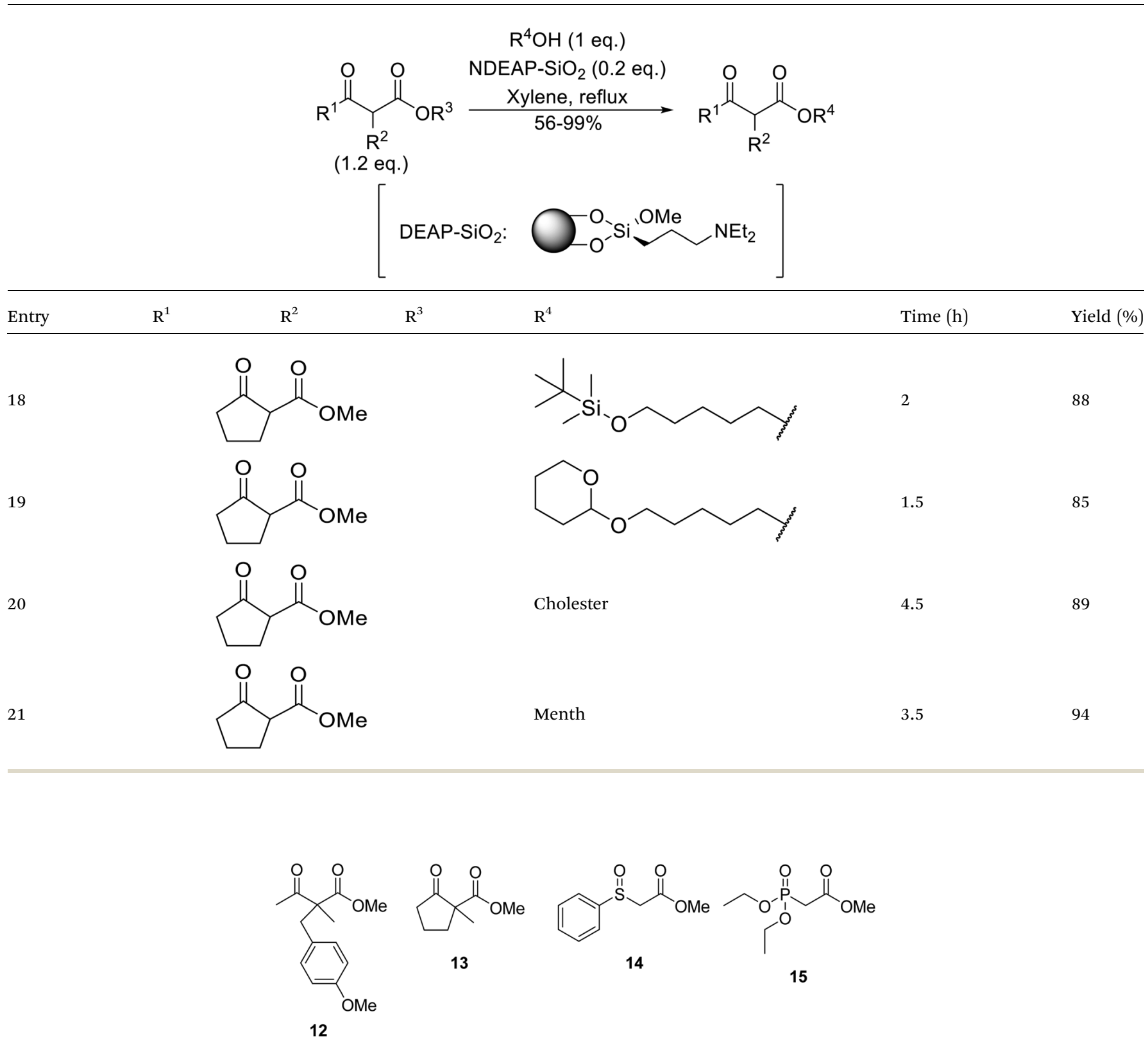

Fig. 3 Incompatible transesterification substrates.

hindered $\beta$-keto ester diethyl acetamidomalonate (18) generating both the monoester and diester products (Scheme 5). ${ }^{54}$ Titanium-mediated transesterifications are not solely limited to $\beta$-keto esters but also encompass other ester substrates. ${ }^{55-57}$

Silver nitrate catalyses the transesterification of $\beta$-keto esters under both conventional and non-conventional conditions. ${ }^{58}$ The use of sonication and microwave irradiation afforded moderate to high yields and reduced reaction times (Table 24). Solvent-free, microwave reactions were faster than sonicated reactions in toluene, which were in turn faster than conventionally heated reactions. Yields remained consistent regardless of the conditions employed. Transesterification was successful with primary (entries 1-7, 9 and 10), secondary (entries 8 and 13) and aromatic alcohols (entry 14). Aromatic alcohols with electron-donating substituents (entry 2-5) reacted faster and in higher yields than electron poor phenols (entry 6).

The same research group also investigated ferrous ammonium sulfate (FAS), also known as Mohr's salt, and ammonium nickel sulfate (ANS) as potential transesterification catalysts (Table 25). ${ }^{59}$ Better results were obtained with FAS rather than ANS. While both catalysts exist in different oxidation states, the nickel catalyst slowly oxidizes over time. The reaction times were similar to those observed with silver nitrate in the order of microwave $<$ sonication $<$ conventional. 


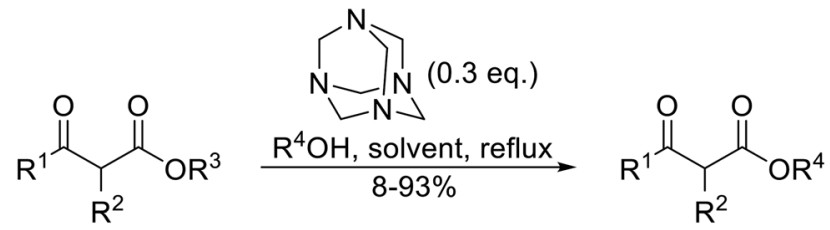

(3 eq.)

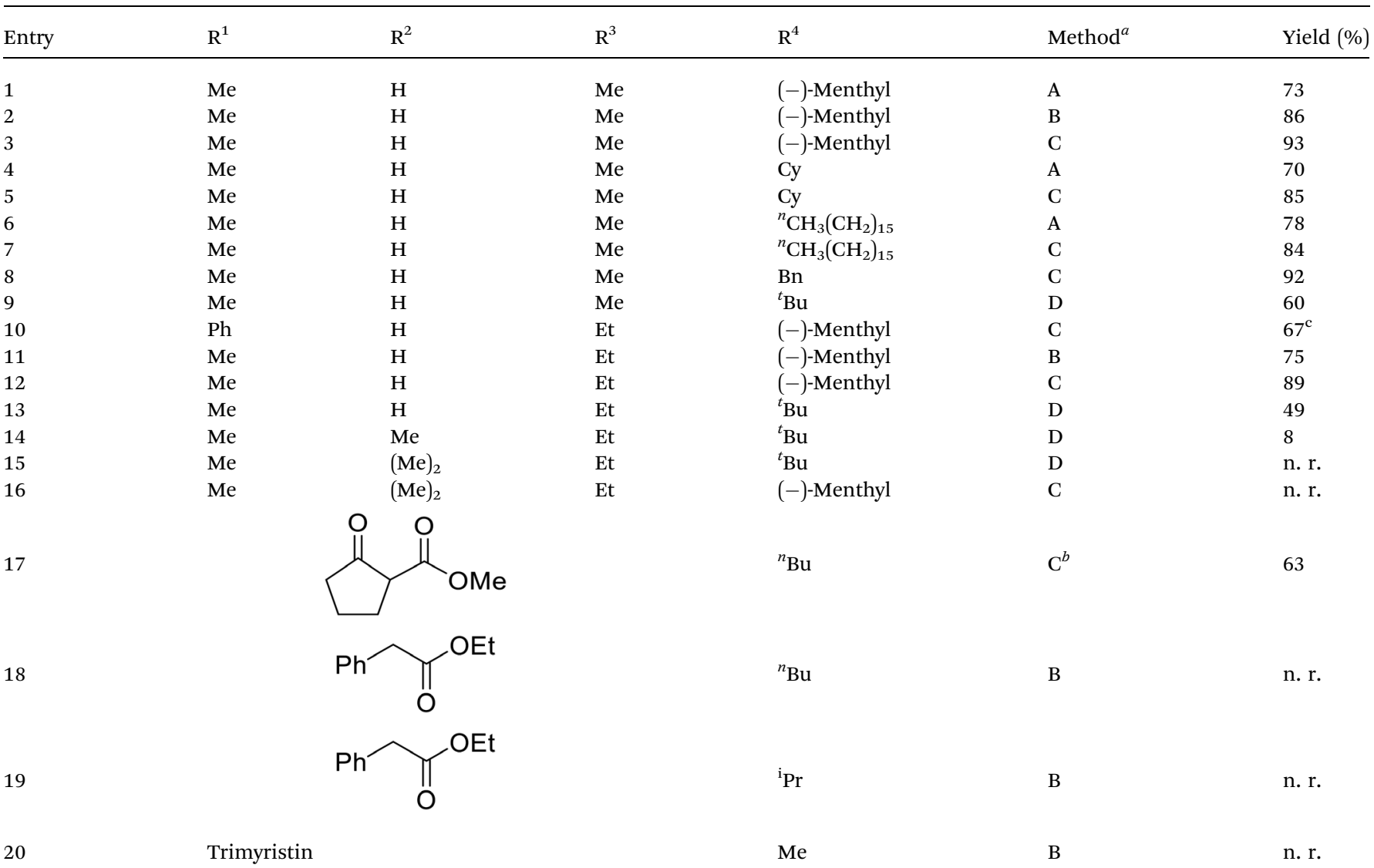

${ }^{a}$ Reagents and conditions: method A: ester (3 eq.), alcohol (1 eq.), HMT (0.3 eq.), toluene; method B: ester (3 eq.), alcohol (1 eq.), HMT (0.3 eq.), toluene, Dean-Stark trap; method C: ester (3 eq.), alcohol (1 eq.), HMT (0.3 eq.), cyclohexane, Dean-Stark trap; method D: ester (3 eq.), alcohol (excess), HMT (0.3 eq.), toluene, reflux, Dean-Stark trap. ${ }^{b} 1$ eq. ester, 1.2 eq. alcohol.

$\mathrm{Ag}-\mathrm{Cu}$ catalysts supported on hydrotalcite-like material $(\mathrm{Ag}-$ $\mathrm{Cu} / \mathrm{HTs}$ ) have recently been developed (Table 26). ${ }^{60} \mathrm{Ag}-\mathrm{Cu}$ has vacant orbitals which likely interact with the two carbonyl groups of the $\beta$-keto esters to form a cyclic intermediate during the reaction. ${ }^{61}$ The $\mathrm{Ag}: \mathrm{Cu}$ molar ratio in the catalyst had a major influence on yields. When monometallic $\mathrm{Cu} / \mathrm{HTs}$ was employed for cinnamyl acetoacetate, the final yield was $72 \%$. By contrast, a maximum yield of $94 \%$ was recorded using an $\mathrm{Ag}: \mathrm{Cu}$ catalyst with a molar ratio of $1.2: 1$. Likewise, when monometallic Ag/HTs was introduced, a lower $86 \%$ yield was achieved. These results suggest that bimetallic $\mathrm{Ag}-\mathrm{Cu}$ nanoparticles are more active than monometallic $\mathrm{Ag}$ or $\mathrm{Cu}$ nanoparticles, most likely due to an interaction between $\mathrm{Cu}$ and $\mathrm{Ag}$.
Electron transfer from $\mathrm{Cu}$ to $\mathrm{Ag}$ within these bimetallic nanoparticles provides better resistance to oxidation than monometallic $\mathrm{Cu}$ nanoparticles. The yields from allylic alcohols (entries 2 and 6) were significantly higher than from aliphatic alcohols (entries 3 and 7). Simple esters afforded lower yields in comparison to $\beta$-keto esters. The transesterification of ethyl acetoacetate with benzyl alcohol, for example, afforded a $97 \%$ yield after five hours (entry 1). By contrast, reaction of ethyl acetate and benzyl alcohol returned a reduced yield of $80 \%$ (entry 12).

Silver triflate has met with some success in the catalysis of transesterifications. ${ }^{62}$ When aliphatic and aromatic alcohols were subjected to esterification with ethyl acetoacetate, the expected 
Table 16 Transesterification using CALB ${ }^{39}$

(4 eq.)

Both iron sulfate and copper sulfate constitute efficient, inexpensive and neutral transesterification catalysts. ${ }^{63}$ Methyl and ethyl $\beta$-keto esters were successfully transesterified with one equivalent of alcohol in the presence of anhydrous iron sulfate or copper sulfate at $80{ }^{\circ} \mathrm{C}$ (Table 28). Primary (entries 1 , 2, 5-7 and 9), secondary (entries 3, 4, 10-12), tertiary (entry 8), aromatic (entries 5-7) and unsaturated alcohols (entries 6, 11 and 12) were all compatible with these conditions. These catalysts are selective towards $\beta$-keto esters, with simple esters remaining unreacted. Sterically crowded tert-butanol was converted to the corresponding tert-butyl ester in a moderate yield (entry 8). In general, the yields obtained using either iron sulfate or copper sulfate were comparable.

An application of this methodology can be seen in the synthesis of prunustatin A, a GRP78 molecular chaperone down-regulator, where the key step is a copper sulfate-mediated intramolecular transesterification to install the 15-membered tetralactone ring skeleton into 22 (Scheme 6). ${ }^{3}$

Magnetic copper ferrite nanoparticles $\left(\mathrm{CuFe}_{2} \mathrm{O}_{4}\right)$ catalyse a variety of organic transformations ${ }^{64}$ and were shown to be similarly effective transesterification catalysts by Bezuidenhoudt and colleagues. ${ }^{65}$ The main attraction of these nanoparticles is their magnetic character, allowing for simple removal by a magnet. The scope of the reaction was evaluated by employing a variety of alcohols (Table 29). Both electronwithdrawing and electron-donating substituents on benzyl alcohol substrates (entries 2-5) gave comparable yields, although the less nucleophilic 4-nitrobenzyl alcohol required an additional two hours to reach completion (entry 2). The reaction of 2- and 4-methoxybenzyl alcohol (entries 5 and 3 respectively) proceeded smoothly despite the tendency of these substrates to undergo dehydroxylation via a benzylic carbocation intermediate.$^{66}$ Aliphatic alcohols proved highly amenable and furnished the corresponding $\beta$-keto esters in excellent yields (entries 11-17). Propargyl alcohol (entry 9) and crotyl alcohol (entry 10) returned the lowest yields. The lower yields are likely due to tendency of the substrates to polymerise in the presence of acids. $\mathrm{CuFe}_{2} \mathrm{O}_{4}$ was successfully recycled eight times, with comparable results on each occasion.

A ceramic catalyst, which consists of zirconia $\left(\mathrm{ZrO}_{2}\right)$ with a yttria $\left(\mathrm{Y}_{2} \mathrm{O}_{3}\right)$ stabilised cubic structure, ${ }^{67}$ accelerates the transesterification of $\beta$-keto esters with primary and secondary alcohols (Table 30). ${ }^{68}$ Conversion to a tert-butyl ester (entry 3), which is often problematic, was also realised by this route albeit in moderate yields. Similarly, unsaturated alcohols reacted smoothly affording the corresponding products in good yields (entries 4 and 7). While conversion from methyl/ethyl esters to higher homologues was facile, the reverse transformation (e.g., menthyl ester to ethyl ester (entry 10)) could also be achieved in somewhat lower yields. This catalyst was selective for $\beta$-keto esters and other esters, such as $\alpha$-keto esters, $\gamma$-keto esters, unsaturated esters or simple esters, failed to react. The conversion of $\beta$-keto esters to their thioester or amide derivatives, which often results in decarboxylation upon hydrolysis, proceeded in moderate yields 
Table 17 Resolution of secondary alcohols using CALB ${ }^{39}$

\begin{tabular}{|c|c|c|c|c|c|c|}
\hline \multirow[b]{2}{*}{ Entry } & \multirow[b]{2}{*}{ Substrate } & \multicolumn{2}{|l|}{ Products } & \multirow[b]{2}{*}{ Conversion } & \multirow[b]{2}{*}{ ee (yield) } & \multirow[b]{2}{*}{ ee (yield) } \\
\hline & & Alcohol & Ester & & & \\
\hline 2 & & & & $51 \%$ & $96 \%(44 \%)$ & $92 \%(42 \%)$ \\
\hline 4 & & & & $51 \%$ & $96 \%(46 \%)$ & $93 \%(40 \%)$ \\
\hline
\end{tabular}

Table 18 Novozyme 435 catalysis $^{41}$

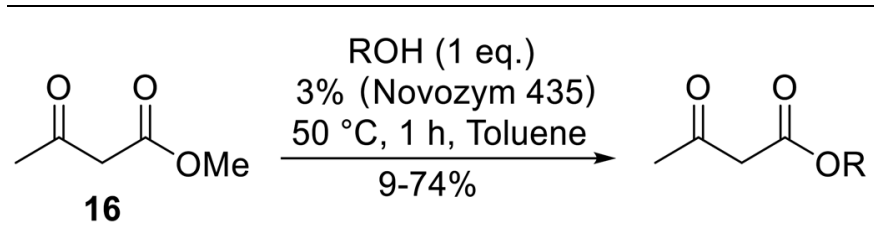

\begin{tabular}{llll}
\hline & & \multicolumn{2}{l}{ Conversion $(\%)$} \\
\cline { 3 - 4 } Entry & $\mathrm{R}$ & Microwave & Conventional \\
\hline 1 & ${ }^{n} \mathrm{Pr}$ & 74 & 57 \\
2 & ${ }^{n} \mathrm{Bu}$ & 72 & 53 \\
3 & ${ }^{n} \mathrm{Pen}$ & 66 & 42 \\
4 & ${ }^{n} \mathrm{Hex}$ & 61 & 34 \\
5 & ${ }^{n} \mathrm{Oct}$ & 55 & 17 \\
6 & ${ }^{n} \mathrm{Dec}$ & 33 & 9 \\
7 & ${ }^{\mathrm{i}} \mathrm{Pr}$ & 68 & 48 \\
8 & ${ }^{\mathrm{i}} \mathrm{Bu}$ & 64 & 38 \\
9 & ${ }^{\text {sec }} \mathrm{Pen}$ & 57 &
\end{tabular}

(entries 11 and 12). Reaction occurred at the primary hydroxyls in the case of 1,2-diols, although a mixture of monoester and diester products was obtained (entry 13). In the case of 2-mercaptoethanol, the hydroxyl reacted preferentially over the thiol (entry 14). For aliphatic amino alcohols, reaction occurred exclusively at the amine in excellent yields (entry 15).

Krishnaiah et al. identified Mn(II) salts as efficient catalysts for the selective transesterification of $\beta$-keto esters with various alcohols (Table 31). ${ }^{69,70}$ Long reaction times were required for $\mathrm{Mn}$ (II) sulfate and Mn(II) carbonate, even at reflux temperatures, but good yields were eventually obtained. The use of ultrasonic conditions reduced reaction times from 16-24 hours to 2.5 hours, while microwave-mediated transformations reached completion within 45 minutes. A loading of 1 equivalent was sufficient across a wide range of alcohols.

Further work within the same group confirmed caesium carbonate to be an effective catalyst under conventional, microwave and ultrasonically-assisted conditions. ${ }^{70}$ Infrared studies suggested that the Brønsted base facilitates generation of an enolate intermediate. As alkoxides are generally more nucleophilic than alcohols, the most likely mechanism proceeds by deprotonation of the alcohol to form an alkoxide nucleophile which then attacks the $\beta$-keto ester. Less sterically hindered primary alcohols reacted faster and returned higher yields compared to secondary or tertiary alcohols.

Prussian blue (iron hexacyanoferrate) is a frequently employed blue-coloured pigment which is also an effective transesterification catalyst. ${ }^{71}$ It exists in water soluble $\left(\mathrm{KFe}_{4}(-\right.$ $\left.\left.\mathrm{Fe}(\mathrm{CN})_{6}\right) \cdot x \mathrm{H}_{2} \mathrm{O}\right)$ and water insoluble $\left(\mathrm{Fe}_{4}\left(\mathrm{Fe}(\mathrm{CN})_{6}\right)_{3} \cdot y \mathrm{H}_{2} \mathrm{O}\right)$ forms and its microporous character makes it an ideal catalytic agent. $^{72}$ A HSAB theory approach supports a reaction 
Table 19 Transesterification of $\beta$-keto esters using a combination of enzymes $^{42}$

\begin{tabular}{|c|c|c|c|c|}
\hline $\mathrm{R}^{1}$ & $\mathrm{OR}_{\text {eq.) }}^{\mathrm{O}}$ & $\begin{array}{r}R \\
\text { enzyr } \\
40^{\circ} \mathrm{C} \\
5\end{array}$ & $\begin{array}{l}\mathrm{H} \\
\underset{\%}{\text { luene }}, 48 \mathrm{~h} \\
\mathrm{\%}\end{array}$ & $\mathrm{OR}^{3}$ \\
\hline Entry & $\mathrm{R}^{1}$ & $\mathrm{R}^{2}$ & $\mathrm{R}^{3}$ & Yield (\%) \\
\hline 1 & Me & Et & $\mathrm{Ph}\left(\mathrm{CH}_{2}\right)_{2}$ & $>99$ \\
\hline 2 & $\mathrm{Me}$ & ${ }^{t} \mathrm{Bu}$ & $\mathrm{Ph}\left(\mathrm{CH}_{2}\right)_{2}$ & $>99$ \\
\hline 3 & Me & Et & $\mathrm{Bn}$ & 98 \\
\hline 4 & $\mathrm{Me}$ & ${ }^{t} \mathrm{Bu}$ & $\mathrm{Bn}$ & 96 \\
\hline 5 & $\mathrm{Me}$ & Et & & $>99$ \\
\hline 6 & $\mathrm{Me}$ & ${ }^{t} \mathrm{Bu}$ & & 94 \\
\hline 7 & $\mathrm{Me}$ & Et & $4-\mathrm{NO}_{2}-\mathrm{C}_{6} \mathrm{H}_{4}\left(\mathrm{CH}_{2}\right)_{2}$ & 89 \\
\hline 8 & $\mathrm{Me}$ & ${ }^{t} \mathrm{Bu}$ & $4-\mathrm{NO}_{2}-\mathrm{C}_{6} \mathrm{H}_{4}\left(\mathrm{CH}_{2}\right)_{2}$ & $>99$ \\
\hline 9 & $\mathrm{Me}$ & Et & $4-\mathrm{MeO}-\mathrm{C}_{6} \mathrm{H}_{4}\left(\mathrm{CH}_{2}\right)_{2}$ & 83 \\
\hline 10 & $\mathrm{Me}$ & ${ }^{t} \mathrm{Bu}$ & $4-\mathrm{MeO}-\mathrm{C}_{6} \mathrm{H}_{4}\left(\mathrm{CH}_{2}\right)_{2}$ & $>99$ \\
\hline 11 & $\mathrm{Me}$ & Et & & 72 \\
\hline 12 & $\mathrm{Me}$ & ${ }^{t} \mathrm{Bu}$ & $\mathrm{OH}$ & $<5$ \\
\hline 13 & $\mathrm{Me}$ & Et & $\mathrm{PhCH}=\mathrm{CHCH}_{2}$ & 92 \\
\hline 14 & $\mathrm{Me}$ & ${ }^{t} \mathrm{Bu}$ & $\mathrm{PhCH}=\mathrm{CHCH}_{2}$ & $<5$ \\
\hline 15 & $4-\mathrm{MeO}-\mathrm{C}_{6} \mathrm{H}_{4}$ & Et & $\mathrm{Ph}\left(\mathrm{CH}_{2}\right)_{2}$ & $>99$ \\
\hline 16 & $4-\mathrm{MeO}-\mathrm{C}_{6} \mathrm{H}_{4}$ & Et & $\mathrm{Bn}$ & $>99$ \\
\hline
\end{tabular}

mechanism similar to caesium carbonate where iron behaves as a hard acid to form an adduct with ethyl acetoacetate.

All three catalysts returned similar yields with comparable reaction times.

\subsection{Non-transition metals}

A zinc/iodine-catalysed transesterification of methyl acetoacetate with primary and secondary alcohols was developed by Chavan and colleagues (Table 32). ${ }^{73}$ It was not possible to transesterify tertiary alcohols under these conditions, possibly due to the increased steric bulk. Introducing a diol led to the crosslinking of esters to generate the doubly transesterified product (entry 10). Notably, 4-methylcoumarins were recovered as the major product when phenols were employed as the nucleophile. These were likely the result of a Pechmann condensation (Scheme 7).
Table 20 Molybdenum-zirconium esterification of methyl acetoacetate ${ }^{43}$

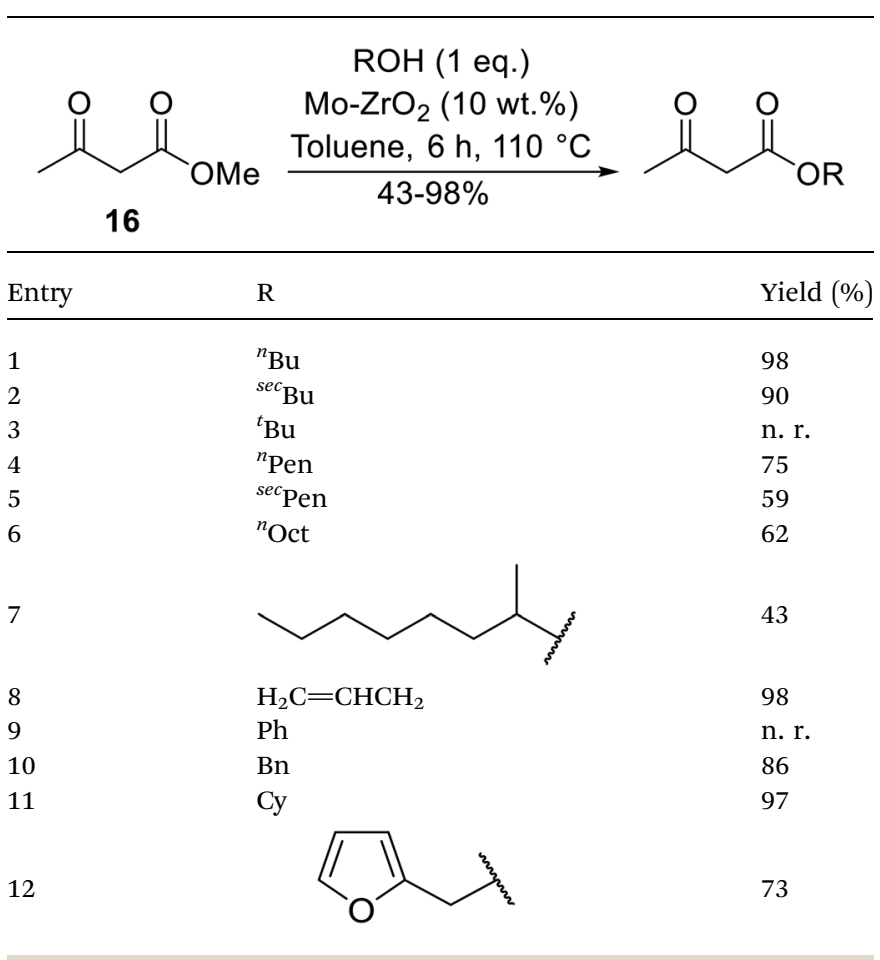

Homogenous catalysts are often characterised by poor chemical and thermal stability which makes catalyst separation and recycling challenging. A strategy to overcome this is to covalently incorporate an organic entity onto inorganic solids. The ideal immobilised catalyst would possess easily accessible active sites which are well dispersed on its surface. Generally, this requires the support to have a reasonably high surface area (typically $>100 \mathrm{~m}^{2} \mathrm{~g}^{-1}$ ). ${ }^{74}$ Sharma and Rawat have developed a recyclable silica-based inorganic-organic hybrid zinc catalyst (Fig. 4). ${ }^{75}$ They coupled a modified silica gel to zinc chloride to create an inorganic-organic interphase catalyst, thus allowing for subsequent separation and recycling. Surface area analysis of this hybrid catalyst revealed a surface area of $116.6 \mathrm{~m}^{2} \mathrm{~g}^{-1}$. Transesterification proceeded smoothly in the presence of this catalyst in toluene at refluxing conditions (Table 33). The immobilized catalyst displayed higher catalytic activity compared to the homogeneous zinc chloride and was reused with no loss in catalytic activity (entry 1 ).

Chemoselective transesterifications employing zinc oxide were investigated by Vallribera and co-workers (Table 34). ${ }^{76}$ Reactions reached completion within 24 hours or less, with the exception of isopropanol (entry 2) and tert-butanol (entry 5) which required 48 and 72 hours respectively. In the case of menthol, changing the stoichiometry from 10 equivalents to 1.5 equivalents afforded comparable yields (entry 10). Both $\alpha$-keto esters (entry 13) and simple esters (entry 14) failed to react under these conditions. Further studies indicated that the reaction is selective for $\beta$-keto esters, as substrates containing both ester and $\beta$-keto ester functionalities reacted exclusively at 


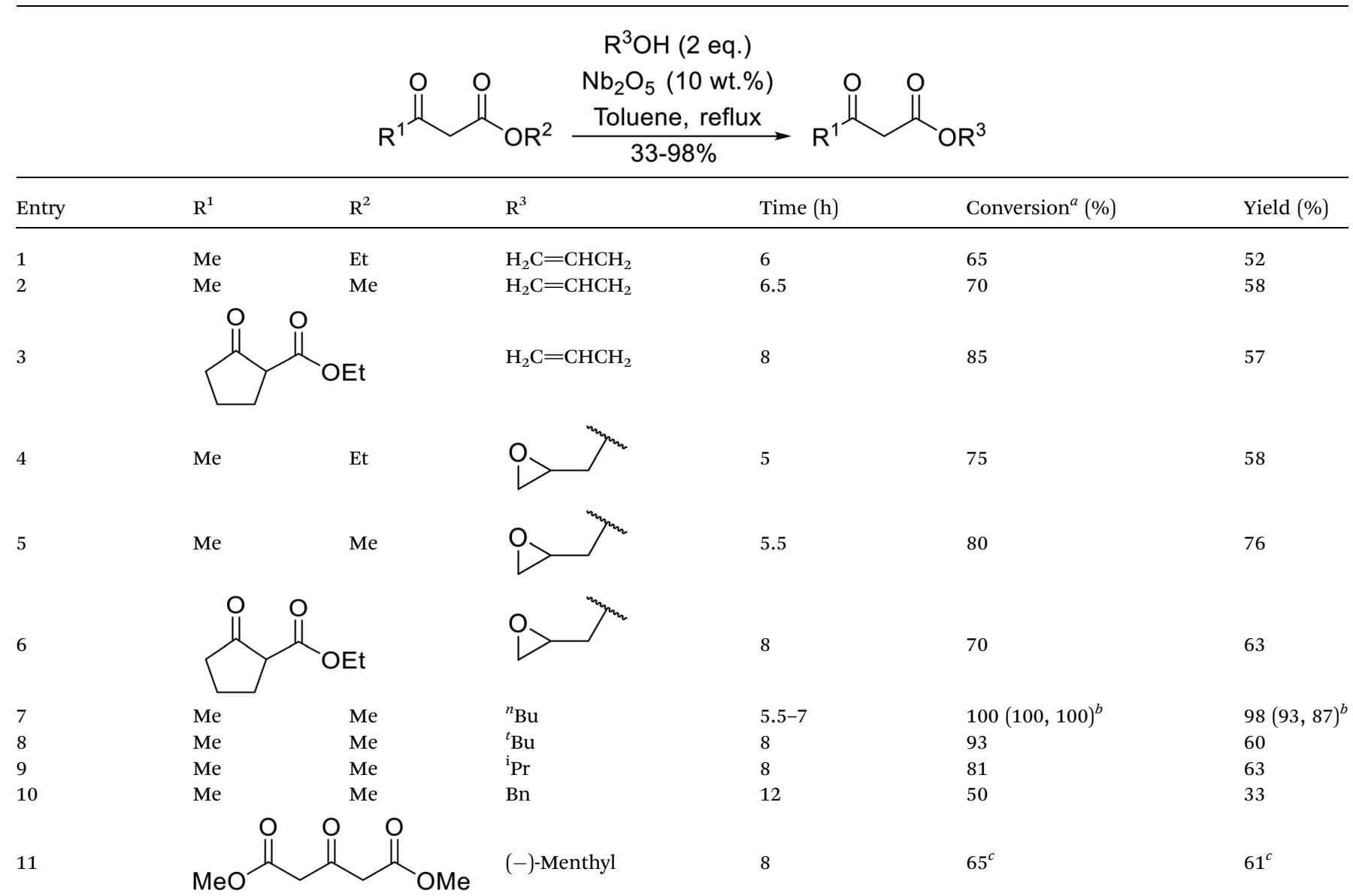

\footnotetext{
${ }^{a}$ Conversion determined by GC of the crude reaction mixture. ${ }^{b}$ Catalyst was recovered and reused three times without appreciable activity loss. ${ }^{c}$ Diester product.
}

the $\beta$-keto ester site (entry 15). More recently, Soliman et al. successfully optimised the transesterification of $\alpha$-keto esters and simple esters utilising zinc oxide nanoparticles, achieving yields up to $97 \% .{ }^{77}$ The modification of both the structure and morphology of the oxide significantly improved activity.

The successful transesterification of $\beta$-keto esters using primary (entries 1, 4-6, 9, 11, 13 and 15), secondary (entries 2, 8, 10, 14 and 16), tertiary (entries 3, 7 and 12), allylic (entries 4, 11, 13 and 15) and benzylic (entry 1) alcohols with catalytic amounts of zinc sulfate at $80{ }^{\circ} \mathrm{C}$ was reported by Bandgar and colleagues (Table 35) ${ }^{78}$ The nature of the alcohol had a significant effect on reaction kinetics, with reaction times ranging from 5.5 hours (entry 2) to 14 hours (entry 3 ) with the same $\beta$ keto ester. A drawback of this catalyst was the requirement for a relatively high catalyst loading of $20 \mathrm{~mol} \%$.

The synthesis of an acetate-bridged tetra-nuclear zinc cluster was pioneered for the first time by Auger and Robin in 1924 via vacuum distillation of zinc acetate hydrate (Fig. 5).${ }^{79}$ Other tetranuclear zinc clusters with different carboxylate ligands, such as
$\mathrm{Zn}_{4}(\mathrm{OCOR})_{6} \mathrm{O}$ (where $\mathrm{R}=\mathrm{Et}, n$-Pr, $t$ - $\mathrm{Bu}$, Ph, etc.), were subsequently prepared using similar synthetic or pyrolytic methods. ${ }^{\mathbf{8 0}}$

Extensive studies on the application of these zinc clusters in organic transformations have been reported by Ohshima and colleagues. ${ }^{81-85}$ Zinc cluster catalysts accelerate the transesterification of both simple methyl esters and $\beta$-keto methyl esters (Table 36). Even sterically congested alcohols such as adamantyl (entry 18) and menthyl alcohol (entry 16) reacted smoothly, with no elimination side-products observed. $\alpha$ Methyl-substituted $\beta$-keto ester was converted to the transesterified product in only moderate yields, even after extended reaction times (entry 3 ), but $\beta$-keto esters derived from 5- or 6membered cyclic ketones were readily transformed in high yields (entries 4 and 5). At reflux, cinnamyl alcohol underwent transesterification to the desired allylic ester but the formation of 1,3-diphenyl-1-oxo-4-pentene was also noted. These side reactions could be avoided by reducing the reaction temperature to $69^{\circ} \mathrm{C}$ (entry 10). Alcohols containing pivaloyl ester (entry 12), silylether (entry 13) or tetrahydropyran (entry 14) protecting 


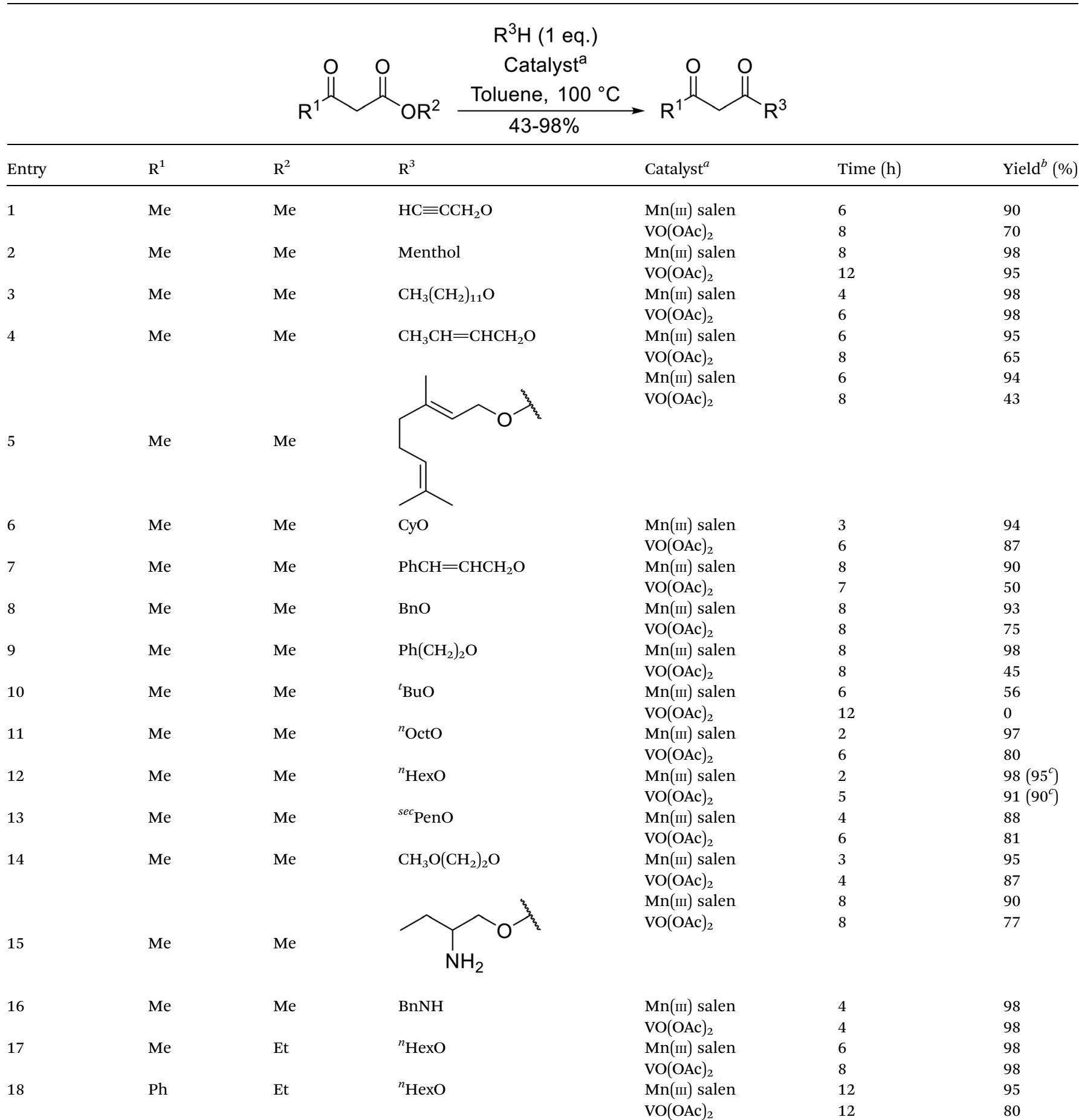

${ }^{a} \mathrm{Mn}(\mathrm{III})$ salen loading: 7 mol\%, VO(OAc) $)_{2}$ loading: $13.5 \mathrm{~mol} \% .{ }^{b}$ Yields determined by ${ }^{1} \mathrm{H}$-NMR, based on $\beta$-keto ester. ${ }^{c}$ Yield after 5 th cycle.

groups reacted smoothly, affording the corresponding esters in high yields. Mildly acidic phenol was unreactive, likely due to the formation of the inactive zinc phenoxide species (entry 20). ${ }^{\mathbf{2}}$ This zinc catalyst was highly compatible with dicarbonyl derivatives of $\beta$-keto esters, leading to double transesterification (entries 6 and 7). In the case of dimethyl malonate and Meldrum's acid, both ester groups were transformed using 2.6 equivalents of alcohol to give dihexyl malonate in good yields (entries 6 and 7). When methyl- $N$-hexyl malonamide was investigated, only the ester group reacted, leaving the remaining 
Table 23 Transesterification using manganese chloride ${ }^{53}$

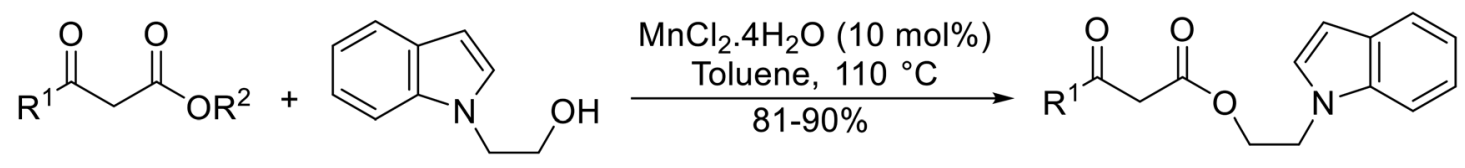

(1.2 eq.)

17 (1 eq.)

\begin{tabular}{lllll}
\hline Entry & $\mathrm{R}^{1}$ & $\mathrm{R}^{2}$ & Time (h) & Yield (\%) \\
\hline 1 & ${ }^{\mathrm{i}} \mathrm{Pr}$ & $\mathrm{Me}$ & 11 & 82 \\
2 & ${ }^{t} \mathrm{Bu}$ & $\mathrm{Et}$ & 11 & 86 \\
3 & ${ }^{n} \mathrm{Pr}$ & $\mathrm{Et}$ & 14 & 87 \\
4 & $\mathrm{Ph}$ & $\mathrm{Et}$ & 11 & 81 \\
5 & $\mathrm{P}-\mathrm{MeO}-\mathrm{C}_{6} \mathrm{H}_{4}$ & $\mathrm{Et}$ & 11 & 88 \\
6 & $\mathrm{Me}$ & ${ }^{t} \mathrm{Bu}$ & 11 & 90
\end{tabular}

Table 24 Transesterification of ethyl acetoacetate using silver nitrate ${ }^{58}$

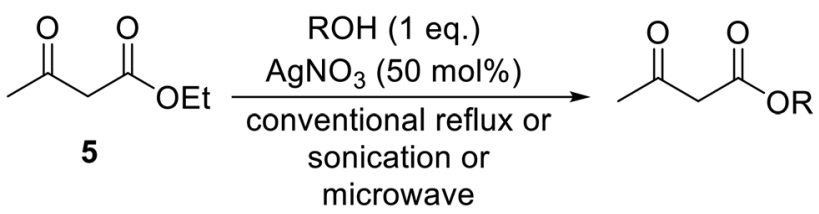

\begin{tabular}{|c|c|c|c|c|c|c|c|}
\hline \multirow[b]{2}{*}{ Entry } & \multirow[b]{2}{*}{$\mathrm{R}$} & \multicolumn{2}{|c|}{ Conventional } & \multicolumn{2}{|l|}{ Sonication } & \multicolumn{2}{|l|}{ Microwave } \\
\hline & & Time (h) & Yield (\%) & Time (min) & Yield (\%) & Time (min) & Yield (\%) \\
\hline 1 & $\mathrm{Bn}$ & 8 & 89 & 30 & 90 & 3 & 91 \\
\hline 2 & $4-\mathrm{Me}-\mathrm{C}_{6} \mathrm{H}_{4} \mathrm{CH}_{2}$ & 9 & 82 & 35 & 83 & 3.5 & 83 \\
\hline 3 & $4-\mathrm{MeO}-\mathrm{C}_{6} \mathrm{H}_{4} \mathrm{CH}_{2}$ & 11 & 83 & 39 & 85 & 4 & 86 \\
\hline 4 & $3,4-(\mathrm{MeO})_{2}-\mathrm{C}_{6} \mathrm{H}_{4} \mathrm{CH}_{2}$ & 11.5 & 83 & 40 & 84 & 4 & 86 \\
\hline 5 & $4-\mathrm{Cl}-\mathrm{C}_{6} \mathrm{H}_{4} \mathrm{CH}_{2}$ & 9 & 80 & 40 & 83 & 5 & 84 \\
\hline 6 & $2-\mathrm{NO}_{2}-\mathrm{C}_{6} \mathrm{H}_{4} \mathrm{CH}_{2}$ & 13 & 71 & 45 & 72 & 6 & 74 \\
\hline 7 & & 12 & 80 & 36 & 83 & 5.5 & 84 \\
\hline 8 & ${ }^{\mathrm{i}} \mathrm{Pr}$ & 12 & 75 & 43 & 77 & 5 & 79 \\
\hline 9 & ${ }^{n} \mathrm{Bu}$ & 11 & 76 & 44 & 77 & 5 & 78 \\
\hline 10 & ${ }^{\mathrm{i}} \mathrm{Bu}$ & 10 & 76 & 45 & 77 & 5 & 79 \\
\hline 11 & ${ }^{t} \mathrm{Bu}$ & 10.5 & 78 & 45 & 79 & 5.5 & 81 \\
\hline 12 & $\mathrm{CH}_{2}=\mathrm{CHCH}_{2}$ & 11.5 & 79 & 43 & 81 & 6 & 81 \\
\hline 13 & Menthyl & 10.5 & 81 & 38 & 83 & 4.5 & 84 \\
\hline 14 & $\mathrm{Ph}$ & 8.5 & 81 & 40 & 82 & 5 & 85 \\
\hline
\end{tabular}


Table 25 Comparison of ferrous ammonium sulfate and ammonium nickel sulfate catalysis ${ }^{59}$

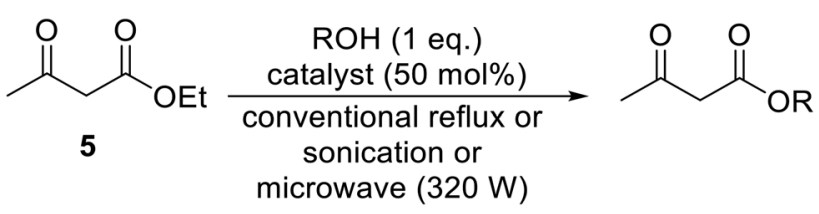

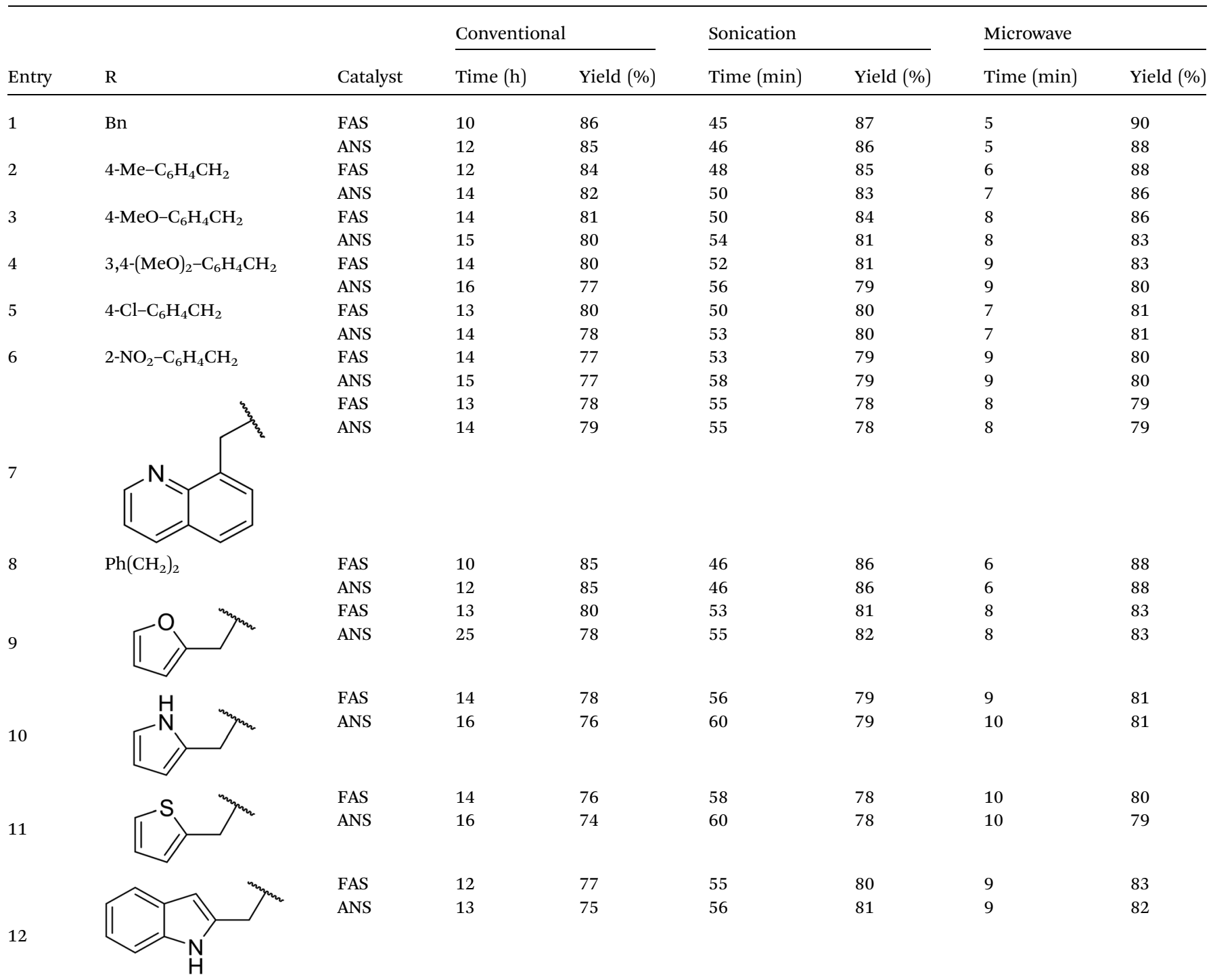

amide intact (entry 8). While a highly acid-sensitive tetrahydropyranyl (THP) ether group was prone to degradation, the addition of $10 \mathrm{~mol} \%$ of 4-DMAP suppressed decomposition to furnish a $94 \%$ yield (entry 14 ).

An extremely rapid transesterification methodology was developed by Goswami et al. using the environmentally benign and inexpensive catalyst $\mathrm{Al}\left(\mathrm{H}_{2} \mathrm{PO}_{4}\right)_{3}{ }^{86}$ The significance of the catalyst lies in its ease of preparation. Upon heating $\mathrm{Al}\left(\mathrm{H}_{2} \mathrm{PO}_{4}\right)_{3}$ to $200{ }^{\circ} \mathrm{C}$, acidic aluminium triphosphate $\left(\mathrm{AlH}_{2} \mathrm{P}_{3} \mathrm{O}_{10}\right) \cdot 2 \mathrm{H}_{2} \mathrm{O}$ is formed, which condenses to give cyclic hexametaphosphate $\mathrm{Al}_{2} \mathrm{P}_{6} \mathrm{O}_{18}{ }^{87}$ The catalyst can be recovered via filtration and reactivated by heating to $200-220^{\circ} \mathrm{C}$ for 30 minutes without loss of activity. As can be seen from Table 37, long chain alkyl (entries 4 and 5), cyclic (entries 7-9), benzylic (entries 10-13) and, notably, allylic (entry 1-3) alcohols reacted rapidly in good yields, despite the extremely low catalyst loadings. Methyl acetoacetate afforded doubly transesterified products on reaction with various diols (entries 14 and 15). Unfortunately, tertiary alcohols did 
Table 26 Catalysis of ethyl acetoacetate using silver-copper nanoparticles ${ }^{60}$

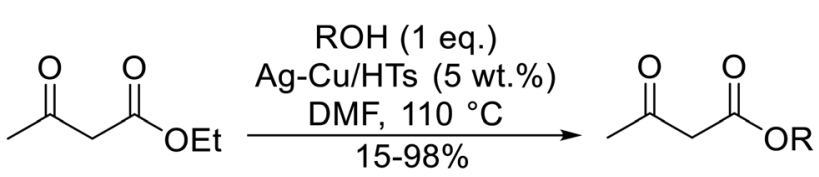

5

\begin{tabular}{|c|c|c|c|}
\hline Entry & $\mathrm{R}$ & Time (h) & Yield $^{a}(\%)$ \\
\hline 1 & $\mathrm{Bn}$ & 5 & 97 \\
\hline 2 & $\mathrm{PhCH}=\mathrm{CHCH}_{2}$ & 6 & $98^{b}$ \\
\hline 3 & $\mathrm{Ph}\left(\mathrm{CH}_{2}\right)_{3}$ & 24 & 89 \\
\hline 4 & & 24 & 52 \\
\hline 5 & & 24 & 15 \\
\hline 6 & $\mathrm{CH}_{3} \mathrm{CH}=\mathrm{CHCH}_{2}$ & 24 & 88 \\
\hline 7 & ${ }^{n} \mathrm{Bu}$ & 24 & 66 \\
\hline 8 & $\mathrm{CH}_{2}=\mathrm{CHCH}_{2}$ & 24 & 76 \\
\hline 9 & ${ }^{n} \mathrm{Pr}$ & 24 & 67 \\
\hline 10 & & 24 & 68 \\
\hline 11 & ${ }^{n} \mathrm{Hex}$ & 24 & 64 \\
\hline 12 & $\mathrm{Bn}$ & 24 & $80^{c}$ \\
\hline
\end{tabular}

${ }^{a}$ Determined by ${ }^{1} \mathrm{H}-\mathrm{NMR}$ analysis of the crude reaction mixture. ${ }^{b}$ Yield of isolated products after column chromatography. ${ }^{c}$ Ethyl acetate starting material.

Table 27 Silver triflate-mediated catalysis ${ }^{62}$

\section{$\mathrm{R}^{2} \mathrm{OH}$ (2 eq.)}

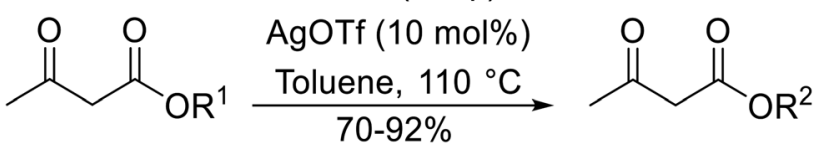

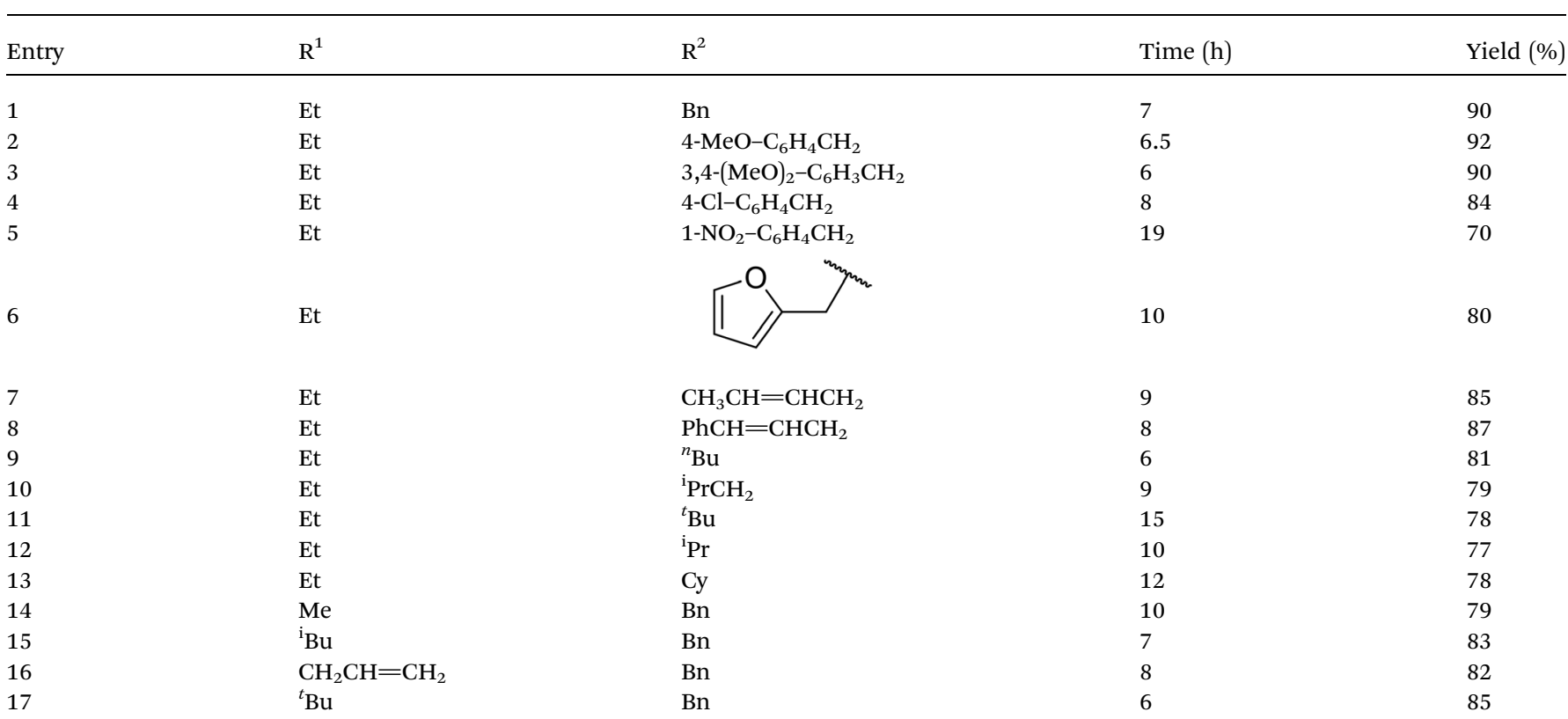


Table 28 Catalysis with iron sulfate or copper sulfate ${ }^{63}$

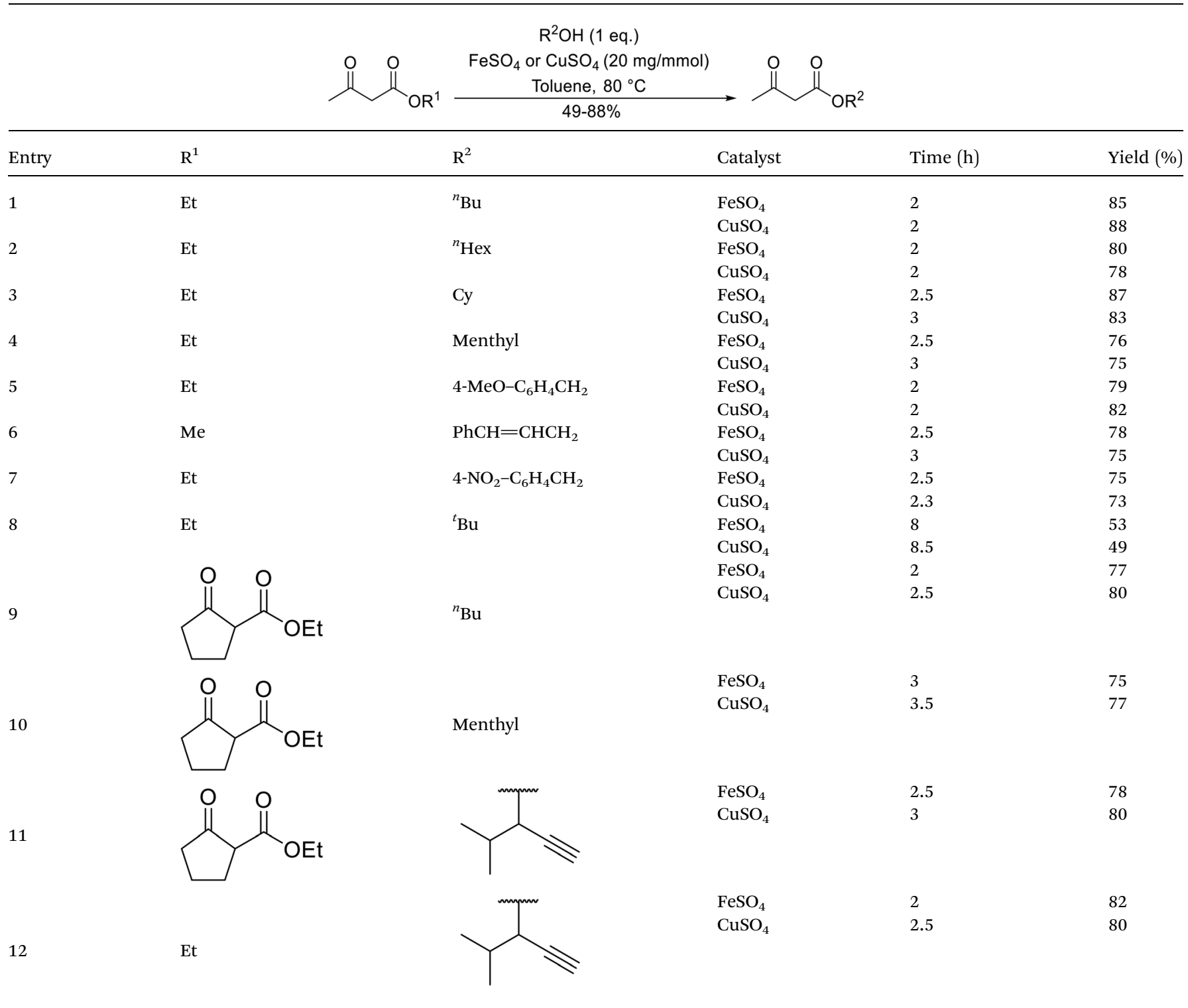<smiles>CCOC(=O)CC(=O)O[C@H](Cc1ccccc1)OC(=O)C(C)OC(=O)[C@@H](NC(=O)[O-])[C@@H](C)OC(=O)[C@H](O)[C@H](C)CC</smiles>

21
$\mathrm{CuSO}_{4}$ (20 eq.)

Toluene, reflux, $5 \mathrm{~h}$ $88 \%$

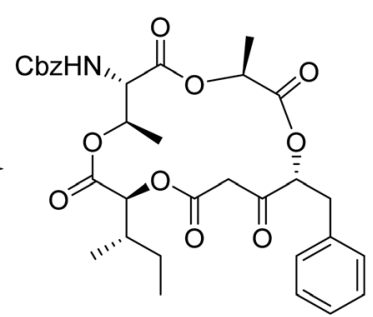

22

Scheme 6 Copper-catalysed intramolecular transesterifications.

not react even after prolonged reaction times. The catalyst is selective for $\beta$-keto esters and $\alpha$-keto esters. The reaction likely proceeds by way of an acyl ketene intermediate as equimolar amounts of methyl acetoacetate and ethyl benzoylacetate afforded methyl benzoylacetate and ethyl acetoacetate respectively via exchange of the alcohol fragments of both $\beta$-keto esters. ${ }^{10}$ 
Table 29 Copper iron oxide-catalysed transesterification of methyl acetoacetate ${ }^{65}$

\begin{tabular}{|c|c|c|c|}
\hline & 16 & H & \\
\hline Entry & $\mathrm{R}$ & Time (h) & Yield (\%) \\
\hline 1 & $\mathrm{Bn}$ & 6 & 94 \\
\hline 2 & $4-\mathrm{NO}_{2}-\mathrm{C}_{6} \mathrm{H}_{4} \mathrm{CH}_{2}$ & 8 & 90 \\
\hline 3 & $4-\mathrm{MeO}-\mathrm{C}_{6} \mathrm{H}_{4} \mathrm{CH}_{2}$ & 6 & 91 \\
\hline 4 & $3-\mathrm{MeO}-\mathrm{C}_{6} \mathrm{H}_{4} \mathrm{CH}_{2}$ & 6 & 91 \\
\hline 5 & $2-\mathrm{MeO}-\mathrm{C}_{6} \mathrm{H}_{4} \mathrm{CH}_{2}$ & 6 & 84 \\
\hline 8 & $\mathrm{PhCH}=\mathrm{CHCH}_{2}$ & 8 & 85 \\
\hline 9 & $\mathrm{HC} \equiv \mathrm{CCH}_{2}$ & 8 & 70 \\
\hline 10 & $\mathrm{CH}_{3} \mathrm{CH}=\mathrm{CHCH}_{2}$ & 8 & 67 \\
\hline 11 & Cy & 8 & 90 \\
\hline 12 & & 8 & 90 \\
\hline 13 & ${ }^{s e c} \mathrm{Bu}$ & 8 & 80 \\
\hline
\end{tabular}

Having demonstrated the catalytic properties of $\mathrm{Mg}-\mathrm{Al}-$ $\mathrm{O}-{ }^{t} \mathrm{Bu}$ hydrotalcite for aldol condensations and the epoxidation of olefins, ${ }^{\mathbf{8 8 , 8 9}}$ Choudary and colleagues subsequently investigated its utility for transesterifications (Table 38). ${ }^{\mathbf{9 0}}$ Unsaturated alcohols, such as allyl alcohol (entry 5) and cinnamyl alcohol (entries 1 and 2), were converted in high yields with no decarboxylative Carroll rearrangement observed. The catalytic system also accelerated transamidations (entry 7). The catalyst is not selective for $\beta$-keto esters as simple esters were also susceptible to reaction under these conditions (entries 3 and 13).

Bismuth halides are relatively non-toxic, inexpensive and easily handled. Due to the weak shielding of the $4 \mathrm{f}$ electrons (lanthanide contraction), bismuth(III) compounds exhibit Lewis acidity. ${ }^{91,92}$ Bismuth chloride facilitates many different transformations including aza-Diels-Alder reactions and one-pot Biginelli reactions. ${ }^{93,94}$ The bismuth chloride-catalysed transesterification of a range of methyl and ethyl $\beta$-keto esters proceeded smoothly with aliphatic (entries 1 and 3), allylic (entries 7 and 12), propargyl (entry 6) and aromatic (entries 2, 4, 5, 8, 10 and 11) alcohols in good to excellent yields (Table 39).95
Comparable yields were recorded regardless of the nature of the substituents on the $\beta$-keto ester substrates.

\section{Lanthanide catalysts}

The catalytic potential of lanthanide catalysts has yet to be fully realised, with only limited examples of their use in synthetic chemistry currently available. The successful application of a ceria-yttria-based Lewis acid $\left(\mathrm{CeO}_{2}-\mathrm{Y}_{2} \mathrm{O}_{3}\right)$ as an acylation catalyst has recently been reported. ${ }^{96}$ Transesterification of $\beta$-keto esters using this system was found to proceed in good to excellent yields (Table 40). ${ }^{97}$ Primary (entries 1, 3, 5-7, 10-12), secondary (entries 2 and 8), tertiary (entry 4), unsaturated (entry 9) and aromatic alcohols (entries 5 and 6) were readily transformed under these conditions. As expected, a reduction in yield was observed with bulky nucleophiles (entry 9). Conversion from methyl/ethyl esters to higher homologues proved straightforward. By contrast, the reverse transformation (e.g., menthyl ester to ethyl ester), 


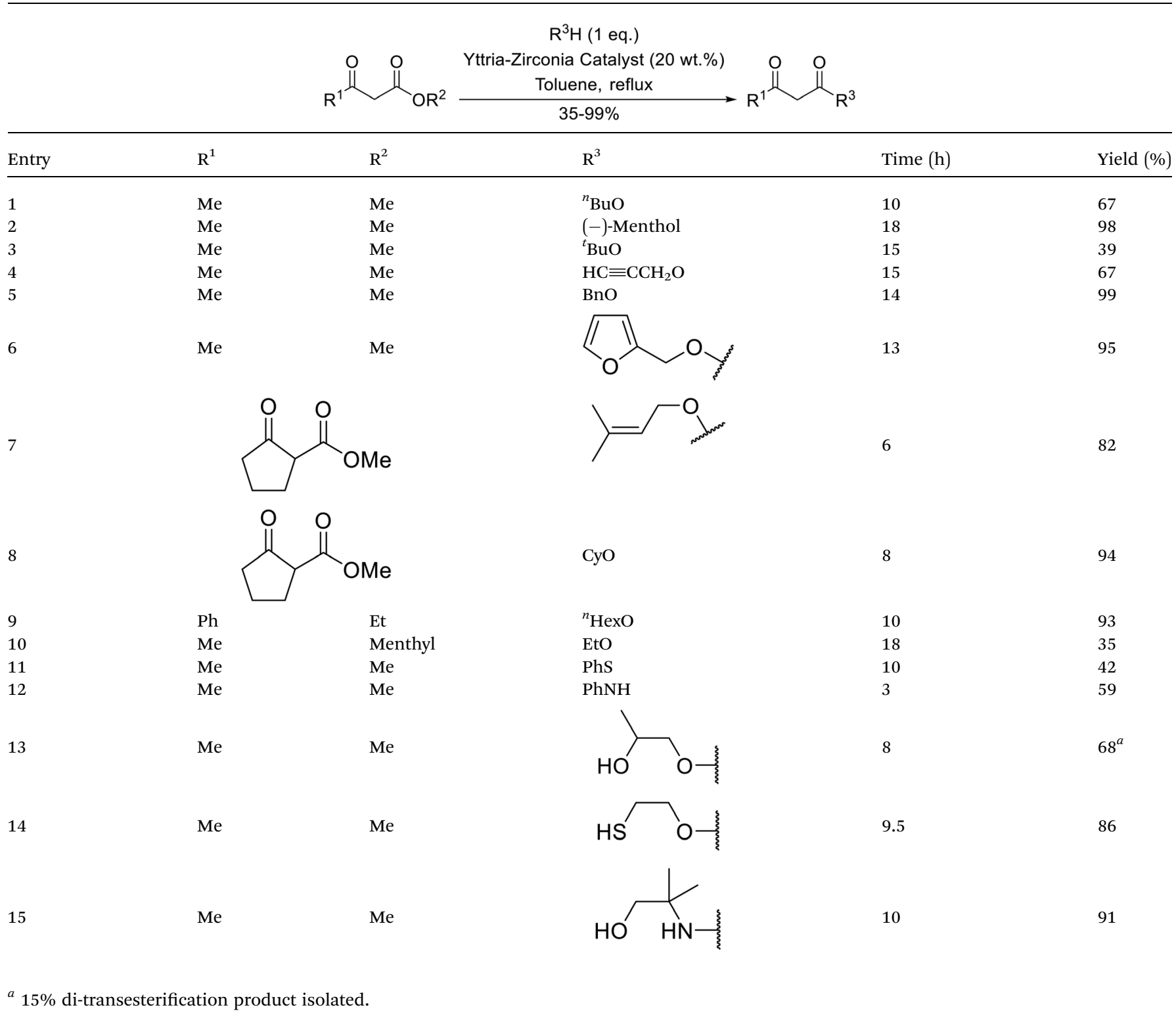

afforded only moderate yields (entry 11). $\alpha$-Keto esters and $\gamma$ keto esters were not compatible with this system. The catalyst may be reactivated by heating to $500{ }^{\circ} \mathrm{C}$ in air without loss of activity.

Ytterbium(III) triflate is an established Lewis acid catalyst for various organic transformations. ${ }^{98}$ Primary (Table 41 entries 15 , and 10-14) and secondary alcohols (entries 6-8) were rapidly converted to the corresponding $\beta$-keto esters. A reduced yield was recorded in the case of tertiary alcohols, due to steric hindrance (entry 9). The catalyst is selective for alcohols over amines (entry 5), which is unexpected, as usually the more nucleophilic amine reacts preferentially.

\section{Clay catalysts}

Natural clays are typically non-corrosive and low cost, making them popular catalysts in organic synthesis. ${ }^{99}$

Montmorillonite $\mathrm{K}-10$ is a type of stratified silicate with acidic properties which can replace conventional acids. ${ }^{\mathbf{1 0 0}}$ This mineral clay is made up of a three-layered structure: one octahedral aluminate layer sandwiched between two octahedral silicate layers. The interlayer cations are exchangeable and in their natural and ion-exchanged form both Brønsted and Lewis acidic catalytic sites are available. Montmorillonite-mediated transesterifications may be conducted in relatively benign hydrocarbon solvents and the catalyst is easily separated and reused (Table 42). Primary (entries 1, 2, 5, 6 and 8-14) and 


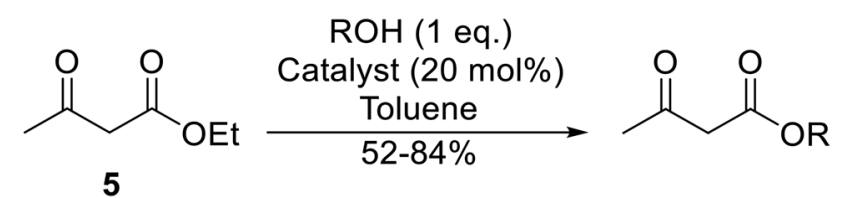

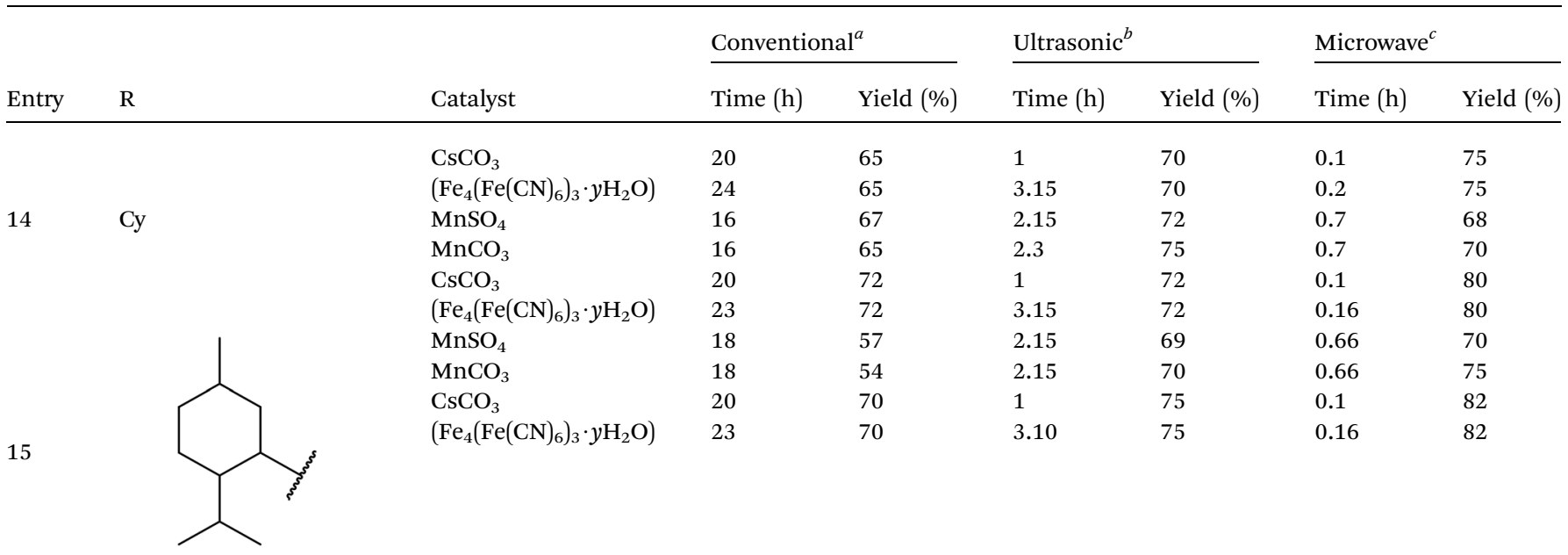

${ }^{a}$ Conventional conditions: $100-110{ }^{\circ} \mathrm{C} .{ }^{b}$ Ultrasonic conditions: sonicator bath, r.t. ${ }^{c}$ Microwave conditions: MW irradiation source consisting of magnetron tube operating at $2.45 \mathrm{GHz}$.

Table 32 Zinc/iodine catalysis ${ }^{73}$

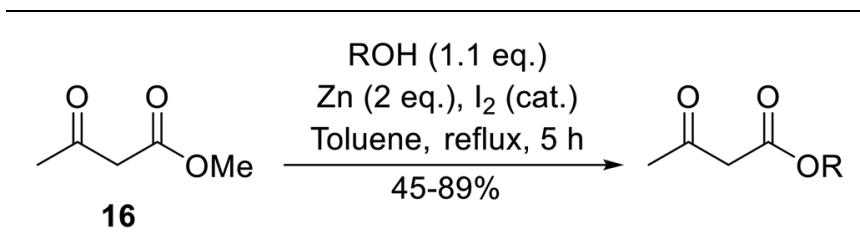

\begin{tabular}{|c|c|c|}
\hline Entry & $\mathrm{R}$ & Yield (\%) \\
\hline 1 & ${ }^{t} \mathrm{Bu}$ & 85 \\
\hline 2 & ${ }^{\mathrm{i}} \mathrm{Pr}$ & 62 \\
\hline 3 & $\mathrm{Bn}$ & 66 \\
\hline 4 & ${ }^{n} \mathrm{Bu}$ & 78 \\
\hline 5 & $\mathrm{H}_{2} \mathrm{C}=\mathrm{CHCH}_{2}$ & 45 \\
\hline 6 & $\mathrm{Cy}$ & 60 \\
\hline 7 & $\mathrm{HC} \equiv \mathrm{CCH}_{2}$ & 71 \\
\hline 8 & & 79 \\
\hline 9 & (-)-Menthol & 89 \\
\hline 10 & $\mathrm{HO}\left(\mathrm{CH}_{2}\right)_{5}$ & $66^{a}$ \\
\hline
\end{tabular}

${ }^{a} 2$ eq. of methyl acetoacetate were used. Diester product isolated.

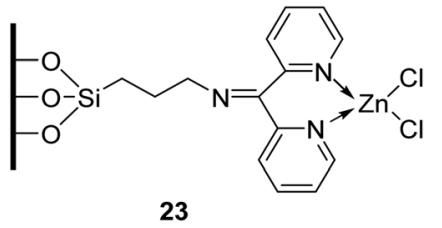

Fig. 4 Zinc chloride immobilised on functionalised silica.

Table 33 Zinc on silica catalysis ${ }^{75}$

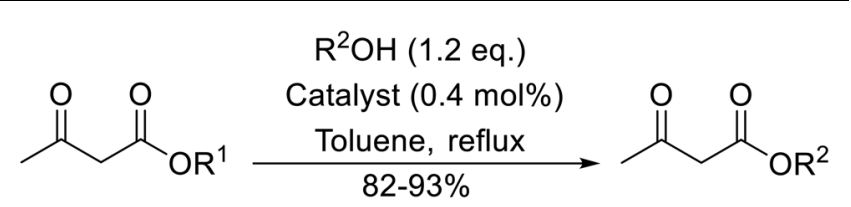

\begin{tabular}{lllll}
\hline Entry & $\mathrm{R}^{1}$ & $\mathrm{R}^{2}$ & Time (h) & Yield (\%) \\
\hline 1 & $\mathrm{Et}$ & ${ }^{n} \mathrm{Bu}$ & 4.0 & $92(60)^{a}$ \\
2 & $\mathrm{Et}$ & ${ }^{s e c} \mathrm{Pen}$ & 4.5 & 88 \\
3 & $\mathrm{Et}$ & $\mathrm{Cy}$ & 4.0 & 90 \\
4 & $\mathrm{Et}$ & $\mathrm{Bn}$ & 4.5 & 89 \\
5 & $\mathrm{Me}$ & $\mathrm{H}{ }_{2} \mathrm{C}=\mathrm{CHCH}_{2}$ & 4.5 & 90 \\
6 & $\mathrm{Et}$ & $\mathrm{PhHC}=\mathrm{CHCH}_{2}$ & 5.0 & 82 \\
7 & $\mathrm{Me}$ & ${ }^{n} \mathrm{Pr}$ & 4.0 & 93
\end{tabular}

${ }^{a}$ Homogenous catalyst used.<smiles>[R]c1ccc(O)cc1</smiles>

Scheme 7 Pechmann condensation using zinc and iodine. 


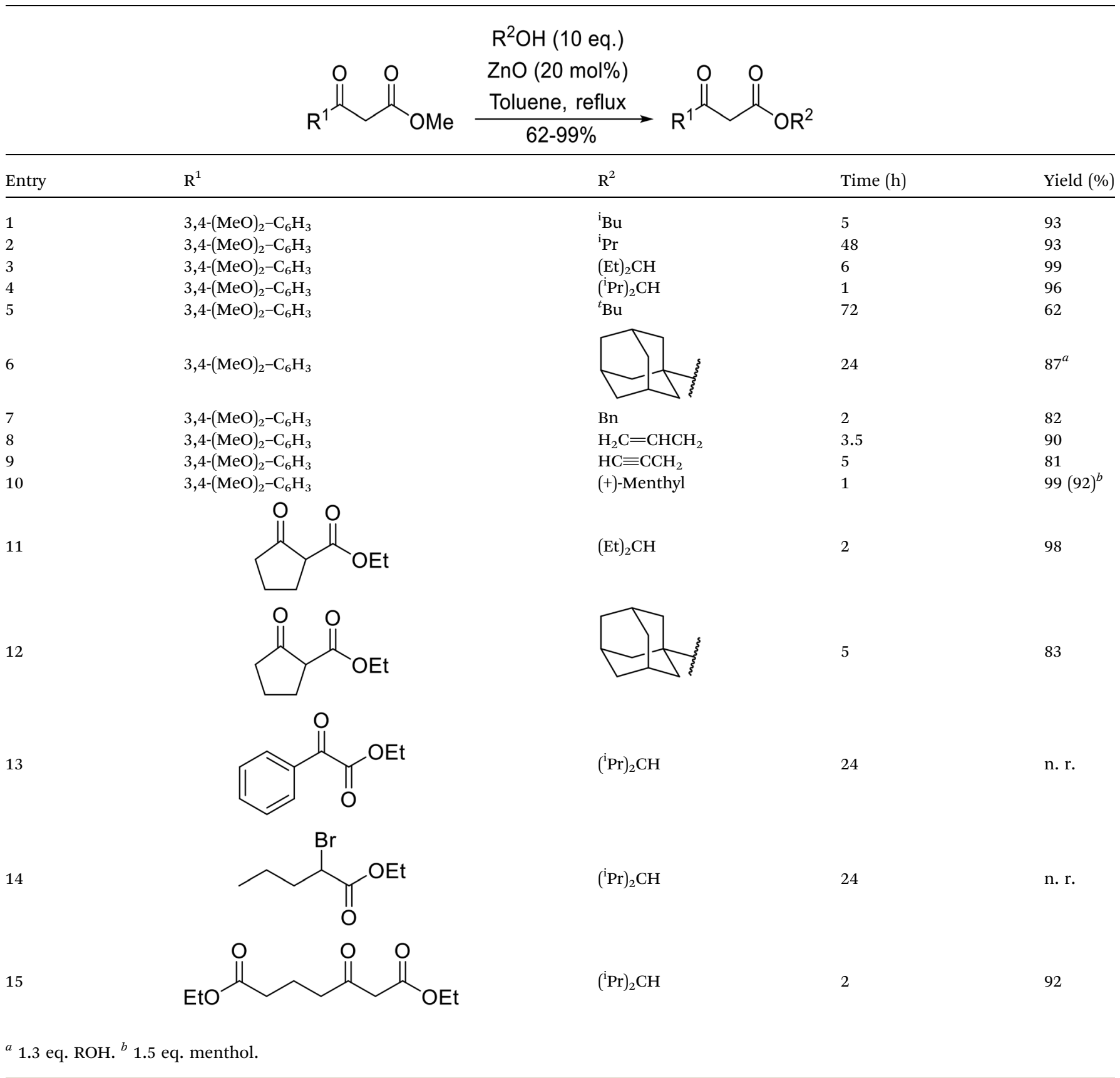

secondary (entries 3 and 7) alcohols were transesterified in good yields without issue. However, a significant reduction in yield with tertiary alcohols was recorded (entry 4 ).

Further studies on montmorillonite K-10 by Perriera and coworkers led to the discovery that this catalyst degraded the carbohydrate-like alcohol $\mathbf{2 5}$, returning the transesterified product in only $34 \%$ yield. Screening of other clays, such as smectite, attapulgite and vermiculite (Fig. 6), identified several promising candidates (Table 43). ${ }^{101}$ The degree of degradation was greatly reduced with these other clays. In general, attapulgite and vermiculite performed better than smectite (entries 1-3). The transformation of anomeric alcohols was unsuccessful as the corresponding esters were too labile (entry 14). Variation of the ketone substituent $\left(\mathrm{R}^{1}\right)$ of the $\beta$-keto esters had a negligible impact on yields. The catalysts could be recovered and reused three times with no appreciable loss in activity.

Kaolinites are $1: 1$ clays consisting of one tetrahedral and one octahedral layer as shown in Fig. 7. The aluminium(III) 


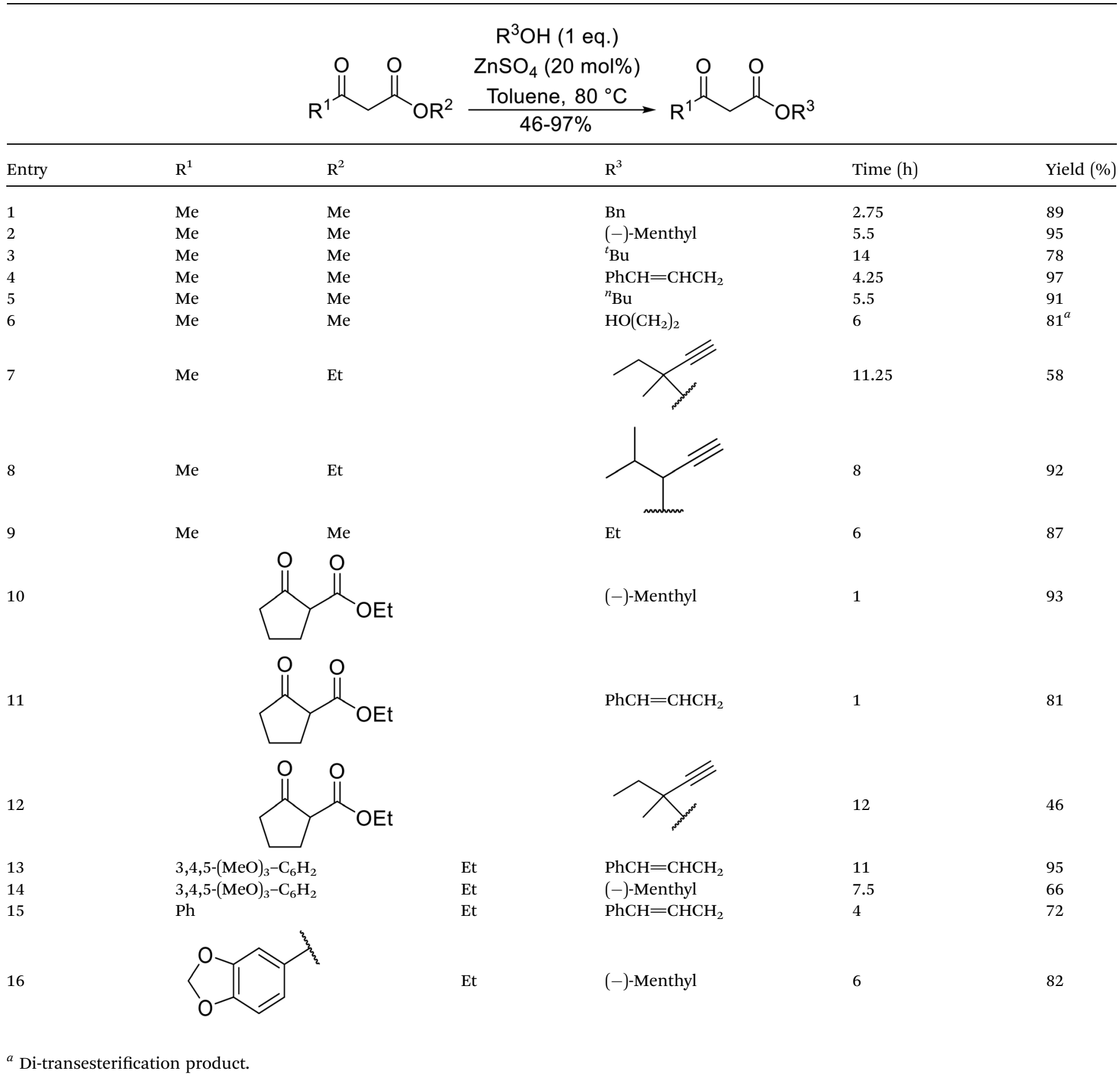

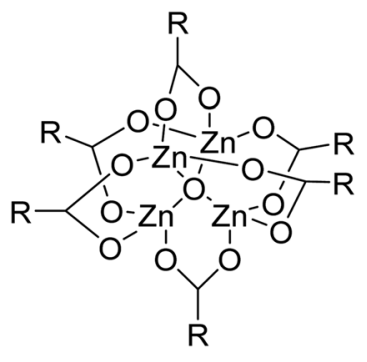

24 cations are bonded to an octahedral arrangement of oxygen anions. Likewise, a tetrahedral layer results from the repeating $\mathrm{SiO}_{4}$ silicate units. ${ }^{102}$

Ponde $e t$ al. have described the application of kaolinitic clay as a reusable, heterogenous catalyst for the selective transesterification of methyl $\beta$-keto esters. ${ }^{105} \mathrm{~A}$ variety of alcohols were transesterified using either montmorillonite K-10 clay or kaolinite clay with similar selectivity and reactivity (Table 44). Additionally, aniline was converted to the corresponding amide

Fig. 5 General structure of tetra-nuclear zinc clusters. 
$\mathrm{R}^{3} \mathrm{OH}$

zinc cluster $24\left(\mathrm{R}=\mathrm{CF}_{3}\right)(1.25 \mathrm{~mol} \%)$
Toluene, reflux

\begin{tabular}{|c|c|c|c|c|c|c|}
\hline Entry & $\mathrm{R}^{1}$ & $\mathrm{R}^{2}$ & $\mathrm{R}^{3}$ & Alcohol (eq.) & Time (h) & Yield (\%) \\
\hline 1 & $\mathrm{Me}$ & $\mathrm{H}$ & ${ }^{n} \mathrm{Hex}$ & 1.2 & 48 & 81 \\
\hline 2 & ${ }^{t} \mathrm{Bu}$ & $\mathrm{H}$ & ${ }^{n} \mathrm{Hex}$ & 1.2 & 48 & 81 \\
\hline 3 & $\mathrm{Ph}$ & $\mathrm{Me}$ & ${ }^{n}$ Hex & 1.2 & 48 & 60 \\
\hline 4 & & & ${ }^{n} \mathrm{Hex}$ & 1.2 & 42 & 87 \\
\hline 5 & & & ${ }^{n}$ Hex & 1.2 & 48 & 97 \\
\hline 6 & & & ${ }^{n} \mathrm{Hex}$ & 2.6 & 68 & 98 \\
\hline 7 & & & ${ }^{n}$ Hex & 2.6 & 68 & $73^{a}$ \\
\hline 8 & ${ }^{n} \mathrm{Hex}-\mathrm{NH}$ & $\mathrm{H}$ & ${ }^{n} \mathrm{Hex}$ & 1.2 & 60 & 77 \\
\hline 9 & $\mathrm{Ph}$ & $\mathrm{H}$ & ${ }^{t} \mathrm{BuCH}_{2}$ & 1.2 & 44 & 89 \\
\hline 10 & $\mathrm{Ph}$ & $\mathrm{H}$ & $\mathrm{PhCH}=\mathrm{CHCH}_{2}$ & 1.2 & 65 & $86^{b}$ \\
\hline 11 & $\mathrm{Ph}$ & $\mathrm{H}$ & $\mathrm{CH}_{3} \mathrm{C} \equiv \mathrm{CCH}_{2}$ & 1.2 & 48 & 82 \\
\hline 12 & $\mathrm{Ph}$ & $\mathrm{H}$ & & 1.2 & 60 & 89 \\
\hline 13 & $\mathrm{Ph}$ & $\mathrm{H}$ & & 1.2 & 48 & 86 \\
\hline 14 & $\mathrm{Ph}$ & $\mathrm{H}$ & & 1.2 & 48 & $94^{c}$ \\
\hline 15 & $\mathrm{Ph}$ & $\mathrm{H}$ & & 1.2 & 44 & 87 \\
\hline 16 & $\mathrm{Ph}$ & $\mathrm{H}$ & (-)-Menthyl & 1.2 & 44 & 93 \\
\hline 17 & $\mathrm{Ph}$ & $\mathrm{H}$ & & 1.5 & 44 & 97 \\
\hline 18 & $\mathrm{Ph}$ & $\mathrm{H}$ & & 2.0 & 72 & 85 \\
\hline 19 & $\mathrm{Ph}$ & $\mathrm{H}$ & ${ }^{t} \mathrm{Bu}$ & 5.0 & 72 & 82 \\
\hline 20 & $\mathrm{Ph}$ & $\mathrm{H}$ & $\mathrm{Ph}$ & 1.2 & 45 & n. $r$. \\
\hline 21 & $\mathrm{Ph}$ & $\mathrm{H}$ & $\mathrm{Bn}$ & 1.2 & 45 & 89 \\
\hline 22 & $\mathrm{Ph}$ & $\mathrm{H}$ & ${ }^{n} \mathrm{Hex}$ & 1.2 & 48 & 86 \\
\hline 23 & $\mathrm{Ph}$ & $\mathrm{H}$ & $\mathrm{Cy}$ & 1.2 & 45 & 95 \\
\hline
\end{tabular}

${ }^{a}$ Dihexyl malonate isolated as major product. ${ }^{b}{ }^{\mathrm{i}} \mathrm{Pr}_{2} \mathrm{O}$ was used as the solvent. ${ }^{c} 10 \mathrm{~mol} \%$ of 4-DMAP was added. 
Table $37 \mathrm{Al}\left(\mathrm{H}_{2} \mathrm{PO}_{4}\right)_{3}$ catalysis $^{86}$

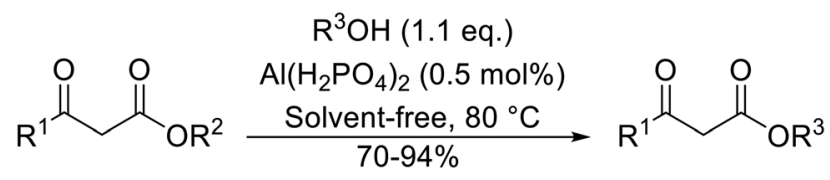

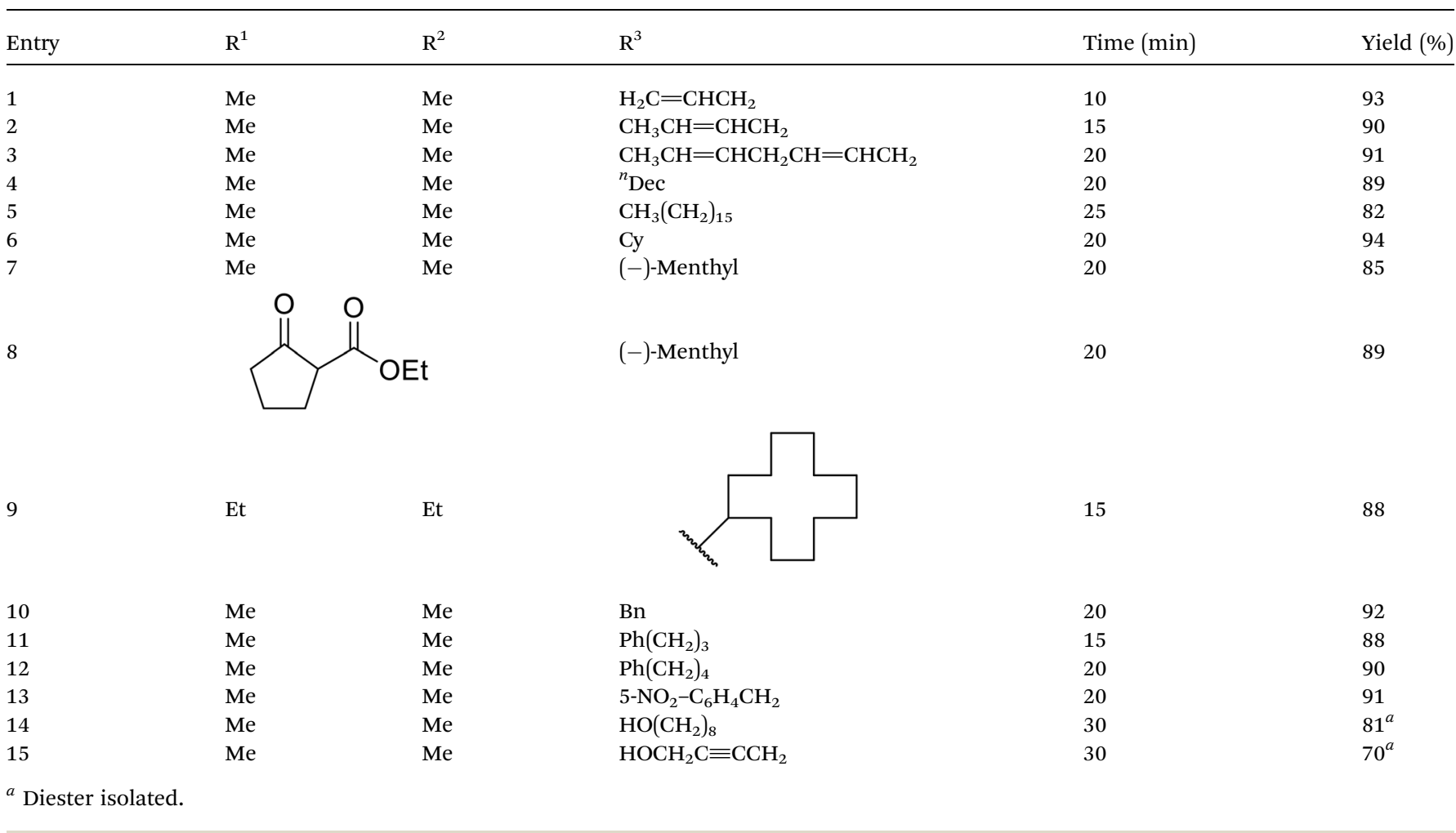

in $60 \%$ yield (entry 30 ). When the keto group at the $\beta$-position was protected, the transesterification was unsuccessful (entry 32). Kaolinitic clay also catalysed the transthioesterification (entries 17-23) and transamidation (entries 24 and 30) of $\beta$-keto esters. The authors further noted that kaolinitic clay facilitated the protection of carbonyls with ethane-1,2-diol, hydroxy thiol, dithiol or propane-1,3-dithiol.

Envirocat EPZG® is a non-toxic, solid-supported reusable reagent with both Lewis acid and Lewis base properties. Its first reported use as a transesterification catalyst was by Bandgar and co-workers. (Table 45). ${ }^{106}$ Primary (entries 1-4, 8, 9, 12 and 14), secondary (entries 5, 6, 10, 11 and 13) and unsaturated alcohols (entries 8, 10, 11 and 14) furnished good yields, with a lower yield resulting from tertiary alcohols (entry 7). Lignantype substrates were also compatible with this methodology (entry 14).

A heterogeneous nanocomposite catalytic system (HNCS) has been developed by Ratti and colleagues. ${ }^{107}$ This is a solid acid catalyst which was prepared by ion exchange of sulfonic acid functionalized ionic liquid (SAFIL) into montmorillonite (MMT) clay interlayers as an organic-inorganic HNCS (Table 46). HNCS accelerated the transesterification of $\beta$-keto esters with primary (entries 1-6 and 9-12), secondary (entries 7, 8, 13 and 14), cyclic (entries 13 and 14) and benzylic (entries 11 and 12) alcohols. SAFIL afforded equally good yields either in an ionic liquid, such as [TMBA] $\mathrm{NTf}_{2}$ (entry 1), or under solvent-free conditions (entry 2). The catalytic activity of the HNCS was measured in the absence and presence of [TMBA] $\mathrm{NTf}_{2}$ solvent (entries 3 and 4 ), and a $0 \%$ yield was recorded when no solvent was present. Recycling experiments confirmed that both the catalyst and ionic liquid may be reused up to seven times.

Vázquez and co-workers compared several different hybrid silica sol-gels as potential catalysts (Table 47). ${ }^{\mathbf{1 0 8 , 1 0 9}}$ SAF (modified silica with AP) and SHF (modified silica with HS) type sol-gels were prepared using 3-aminopropyltriethoxysilane (AP) and 1,1,1,3,3,3-hexamethyldisilazane (HS) respectively. Functionalised silica sol-gels with different modifier loadings (SAF, SAFI and SAFII) and combinations of modifiers (SAHMI and SAHMII) were also examined (Table 47). The use of pure silica (entry 1), SAFI (entry 4) or SAFII (entry 5) to catalyse the reaction of ethyl acetoacetate with 3-phenylpropanol resulted in unwanted ether formation due to self-coupling of the alcohol. The highest yields and shortest reaction times were associated with the SHF catalyst (entry 2). Similar activity was noted for SAHMII (entry 7), but a surprisingly poor yield of $49 \%$ was recorded with the SAHMI catalyst (entry 6). The nature of the 
Table $38 \mathrm{Mg}-\mathrm{Al}-\mathrm{O}-{ }^{t} \mathrm{Bu}$ hydrotalcite catalysis ${ }^{90}$

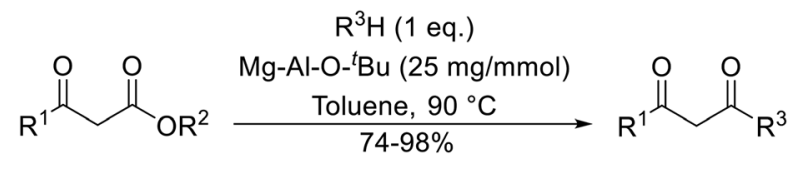

\begin{tabular}{llllll}
\hline Entry & $\mathrm{R}^{1}$ & $\mathrm{R}^{2}$ & $\mathrm{R}^{3}$ & Time (h) \\
\hline 1 & $\mathrm{Me}$ & $\mathrm{Et}$ & $\mathrm{PhCH}=\mathrm{CHCH}_{2} \mathrm{O}$ & 2 & \\
2 & $\mathrm{Ph}$ & $\mathrm{Me}$ & $\mathrm{PhCH}=\mathrm{CHCH}_{2} \mathrm{O}$ & 2 & 74 \\
& & & & 90
\end{tabular}

3<smiles>COC(=O)c1ccccc1O</smiles>

$\mathrm{BnO}$

98

CyO 2

$\mathrm{H}_{2} \mathrm{C}=\mathrm{CHCH}_{2} \mathrm{O}$

${ }^{n} \mathrm{PrO}$

$\mathrm{PhNH}$

$\mathrm{CyO}$

${ }^{n} \mathrm{PenO}$

${ }^{n}$ OctO

(-)-Menthyl

${ }^{n} \mathrm{HexO}$

2
1.5
1
2
2
3
2.5
2
2

97

95

96

95

98

97

97

$98(97)^{a}$<smiles>COC(=O)c1ccccc1O</smiles>

${ }^{n}$ OctO

92

\footnotetext{
${ }^{a}$ Yield after 6th cycle.
}

Table 39 Bismuth(III) chloride-catalysed transesterification ${ }^{95}$

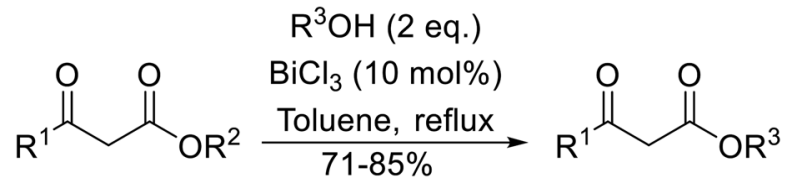

\begin{tabular}{|c|c|c|c|c|c|}
\hline Entry & $\mathrm{R}^{1}$ & $\mathrm{R}^{2}$ & $\mathrm{R}^{3}$ & Time (h) & Yield (\%) \\
\hline 1 & $\mathrm{Me}$ & $\mathrm{Me}$ & $\mathrm{Bu}$ & 3 & 85 \\
\hline 2 & & $\mathrm{Me}$ & $\mathrm{Bn}$ & 4 & 75 \\
\hline 3 & ${ }^{t} \mathrm{Bu}$ & Et & (+)-Menthyl & 4.5 & 71 \\
\hline 4 & ${ }^{\mathrm{i}} \mathrm{Pr}$ & Et & $\mathrm{Bn}$ & 3 & 72 \\
\hline 5 & ${ }^{t} \mathrm{Bu}$ & $\mathrm{Et}$ & $\mathrm{Bn}$ & 3.5 & 78 \\
\hline 6 & $\mathrm{Ph}$ & Et & $\mathrm{HC} \equiv \mathrm{CCH}_{2}$ & 3 & 81 \\
\hline 7 & ${ }^{\mathrm{i}} \mathrm{Pr}$ & Et & $\mathrm{H}_{2} \mathrm{C}=\mathrm{CH}\left(\mathrm{CH}_{2}\right)_{2}$ & 3 & 79 \\
\hline 8 & ${ }^{\mathrm{i}} \mathrm{Pr}$ & Et & $\mathrm{Ph}\left(\mathrm{CH}_{2}\right)_{3}$ & 2.5 & 84 \\
\hline 9 & ${ }^{\mathrm{i}} \mathrm{Pr}$ & Et & (-)-Menthyl & 4.5 & 73 \\
\hline 10 & $\mathrm{Ph}$ & Et & $\mathrm{Bn}$ & 3 & 85 \\
\hline 11 & & & $\mathrm{Bn}$ & 4 & 82 \\
\hline 12 & & & $\mathrm{H}_{2} \mathrm{C}=\mathrm{CHCH}_{2}$ & 4.5 & 85 \\
\hline
\end{tabular}


Table 40 Transesterification catalysis using a ceria-yttria-based Lewis acid ${ }^{97}$

\begin{tabular}{|c|c|c|c|c|c|}
\hline & & & $\begin{array}{c}\mathrm{R}^{3} \mathrm{OH} \text { (1 eq.) } \\
\mathrm{CeO}_{2}-\mathrm{Y}_{2} \mathrm{O}_{3}(15 \text { wt\%) } \\
\text { Toluene, reflux } \\
5-98 \%\end{array}$ & & \\
\hline Entry & $\mathrm{R}^{1}$ & $\mathrm{R}^{2}$ & $\mathrm{R}^{3}$ & Time (h) & Yield (\%) \\
\hline 1 & $\mathrm{Me}$ & $\mathrm{Me}$ & ${ }^{n}$ Hex & 10 & 95 \\
\hline 2 & $\mathrm{Me}$ & $\mathrm{Me}$ & Cy & 8 & 95 \\
\hline 3 & $\mathrm{Me}$ & $\mathrm{Me}$ & $\mathrm{Me}$ & 9 & 98 \\
\hline 4 & $\mathrm{Me}$ & $\mathrm{Me}$ & ${ }^{t} \mathrm{Bu}$ & 15 & 30 \\
\hline 5 & $\mathrm{Me}$ & $\mathrm{Me}$ & $\mathrm{Bn}$ & 10 & 95 \\
\hline 6 & $\mathrm{Me}$ & $\mathrm{Me}$ & & 15 & 65 \\
\hline 7 & & & ${ }^{n} \mathrm{Bu}$ & 9 & 82 \\
\hline 8 & & & Cy & 8 & 97 \\
\hline 9 & & & & 10 & 85 \\
\hline 10 & $\mathrm{Ph}$ & $\mathrm{Me}$ & ${ }^{n}$ Hex & 8 & 93 \\
\hline 11 & $\mathrm{Me}$ & & Et & 24 & $5\left(18^{a}\right)$ \\
\hline 12 & $\mathrm{Me}$ & $\mathrm{Me}$ & ${ }^{n} \mathrm{Bu}$ & 8 & 95 \\
\hline
\end{tabular}

surface groups of the SAHMI and SAHMII catalysts afforded better hexamethyldisilazane dispersion and improved accessibility to the active sites. For each alcohol tested, comparable yields were obtained with either ethyl acetoacetate (entries 113) or methyl acetoacetate (entries 15-21).

\section{Mesoporous and microporous material-based catalysts}

Mesoporous materials contain pores that are between $2 \mathrm{~nm}$ and $50 \mathrm{~nm}$ in diameter, while microporous materials have a pore size of less than $2 \mathrm{~nm}$ in diameter. ${ }^{110}$ These materials possess a large surface area, making them ideal for the purpose of catalysis.

Catalysts are typically prepared via a polymerisation reaction between ethylenediamine (EDA) and carbon tetrachloride (Scheme 8). Mesoporous carbon nitride (MCN) is a carbonbased material that boasts a well-ordered and tunable porous structure, with an extremely high nitrogen content. ${ }^{111}$ Varying the ratio of EDA to carbon tetrachloride allows for the pore diameter, specific surface area and the nitrogen content to be altered.

Vinu and co-workers have found that MCN-1, derived from SBA-15, is highly active in the solvent-free transesterification of cyclic, aromatic, long and short chain primary alcohols to afford 
Table 41 Ytterbium triflate-mediated transesterifications ${ }^{98}$

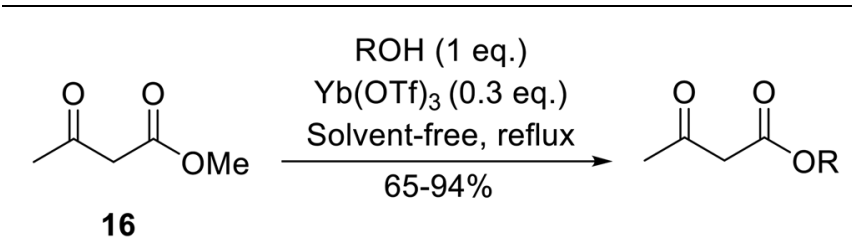

\begin{tabular}{|c|c|c|c|}
\hline Entry & $\mathrm{R}$ & Time (h) & Yield (\%) \\
\hline 1 & Et & 3 & 94 \\
\hline 2 & ${ }^{n} \mathrm{Bu}$ & 3 & 94 \\
\hline 3 & $\left(\mathrm{CH}_{3}\right)_{2} \mathrm{CHCH}_{2}$ & 3 & 90 \\
\hline 4 & ${ }^{n}$ Oct & 3 & 92 \\
\hline 5 & & 3 & 90 \\
\hline 6 & & 3 & 89 \\
\hline 7 & Cy & 3 & 91 \\
\hline 8 & Menthyl & 3 & 85 \\
\hline 9 & ${ }^{t} \mathrm{Bu}$ & 4.5 & 65 \\
\hline 10 & $\mathrm{Bn}$ & 3 & 90 \\
\hline 11 & $\mathrm{Ph}\left(\mathrm{CH}_{2}\right)_{2}$ & 3 & 87 \\
\hline 12 & & 4 & 80 \\
\hline 13 & $\mathrm{H}_{2} \mathrm{C}=\mathrm{CHCH}_{2}$ & 3 & 80 \\
\hline 14 & & 4 & 82 \\
\hline
\end{tabular}

Table 42 Montmorillonite K-10 catalysis $^{100}$

\begin{tabular}{|c|c|c|c|c|}
\hline & OR & $\begin{array}{r}\mathrm{R}^{2} \mathrm{OH}(1 \\
\text { Mont. K-10 }(0.0 \\
\text { Toluene, } \mathrm{r} \\
59-96\end{array}$ & ol) & ${ }_{\mathrm{OR}^{2}}$ \\
\hline Entry & $\mathrm{R}^{1}$ & $\mathrm{R}^{2}$ & Time (h) & Yield (\%) \\
\hline 1 & $\mathrm{Me}$ & ${ }^{n} \mathrm{Bu}$ & 3 & 96 \\
\hline 2 & $\mathrm{Me}$ & ${ }^{n}$ Pen & 3 & 91 \\
\hline 3 & $\mathrm{Me}$ & ${ }^{s e c}$ Pen & 2.5 & 87 \\
\hline 4 & $\mathrm{Me}$ & ${ }^{t} \mathrm{Bu}$ & 4 & 59 \\
\hline 5 & $\mathrm{Me}$ & ${ }^{n}$ Hep & 3 & 92 \\
\hline 6 & $\mathrm{Me}$ & ${ }^{n}$ Dec & 3 & 93 \\
\hline 7 & $\mathrm{Me}$ & Сy & 2.5 & 89 \\
\hline 8 & $\mathrm{Me}$ & $\mathrm{H}_{2} \mathrm{C}=\mathrm{CHCH}_{2}$ & 2.5 & 92 \\
\hline 9 & $\mathrm{Me}$ & $\mathrm{Bn}$ & 3.5 & 89 \\
\hline 10 & $\mathrm{Me}$ & & 4 & 87 \\
\hline 11 & Et & ${ }^{n} \mathrm{Bu}$ & 3 & 82 \\
\hline 12 & $\mathrm{Et}$ & ${ }^{n}$ Dec & 3 & 86 \\
\hline 13 & Et & $\mathrm{Cy}$ & 2.5 & 84 \\
\hline 14 & Et & $\mathrm{Bn}$ & 3.5 & 80 \\
\hline
\end{tabular}<smiles>COC12OC(C)(C)C(CO)(OC1(C)C)O2</smiles>
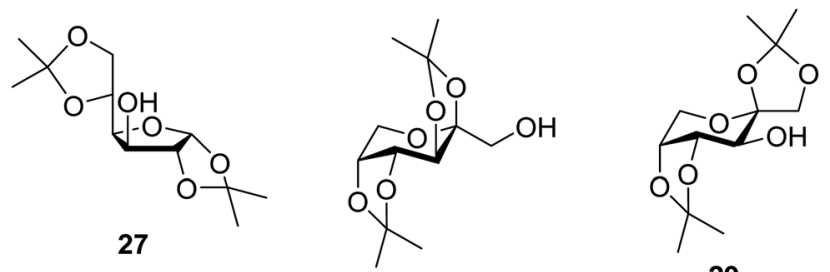

28

29

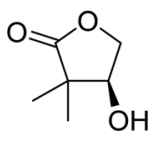

30

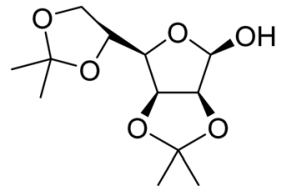

31

Fig. 6 Carbohydrate-like alcohols for transesterification.

the corresponding $\beta$-keto esters in yields up to $69 \%$ in 6 hours. ${ }^{113} \mathrm{MCN}-1$ performed better with aliphatic alcohols (e.g. $n$ butanol and $n$-octanol) than cyclic alcohols (e.g. cyclohexanol and furfuryl alcohol) or aromatic alcohols (e.g. benzyl alcohol). A $2 \%$ catalyst loading was found to be optimal, with higher loadings leading to lower yields, likely due to a poisoning effect. By comparing the activity of MCN-1 with mesocarbon (CMK-3), it was concluded that the basic amine groups along the walls of the material offer strong Lewis basic sites. Recycling studies were also performed, and MCN-1 could be reused at least three times without any significant loss of catalytic activity.

As an alternative to mesoporous carbon nitride, nitrogencontaining ordered mesoporous carbon (NOMC) material offers many advantages in both preparation and application. ${ }^{\mathbf{1 1 4}}$ The nitrogen percentage can be modified with average pore sizes of 3.4$3.7 \mathrm{~nm}$. NOMC-550 displays superior catalytic activity compared to other NOMC materials due to its optimal surface area and nitrogen composition. $\mathrm{Xu}$ et al. employed NOMC-550 for the transesterification of $\beta$-keto esters (Table 48). ${ }^{115}$ A reaction time of 6 hours and temperature of $100{ }^{\circ} \mathrm{C}$ are optimum for this catalyst. After five consecutive reactions, there was little fall off in catalytic activity. Aliphatic alcohol (entries 1 and 2), cyclic alcohols (entry 3) and aromatic alcohols (entries 4-6) afforded moderate conversions.

Kantam and Sreekanth have investigated a heterogeneous guanidine-derived catalyst, 1,5,7-triazabicyclo[4.4.0]dec-5-ene (TBD), anchored on MCM-41 mesoporous material (TBDMCM) (Fig. 8). ${ }^{116} n$-Butyl esters were found to react faster and in higher yields with ethyl acetoacetate (Table 49, entry 3) than with methyl acetoacetate (entry 2). When an aminoalcohol was 
Table 43 Comparison of smectite, attapulgite or vermiculite clays ${ }^{101}$

\begin{tabular}{|c|c|c|c|c|c|}
\hline \multirow[b]{2}{*}{ Entry } & \multirow[b]{2}{*}{$\mathrm{R}^{1}$} & $\mathrm{R}_{(1.2}^{\stackrel{O}{1}}$ & $\begin{array}{r}\mathrm{R}^{2} \mathrm{OH} \\
\text { Clay }(20 \mathrm{mo} \\
\text { Toluene, reflux } \\
50-98 \%\end{array}$ & $\stackrel{\mathrm{OR}}{ }^{2}$ & \multirow[b]{2}{*}{ Vermiculite yield (\%) } \\
\hline & & Alcohol & Smectite yield (\%) & Attapulgite yield (\%) & \\
\hline 1 & $\mathrm{Me}$ & 25 & 73 & 93 & 93 \\
\hline 2 & $\mathrm{Ph}$ & 25 & 72 & 75 & 76 \\
\hline 3 & $\mathrm{Me}$ & 26 & 76 & 86 & 98 \\
\hline 4 & $\mathrm{Ph}$ & 26 & 89 & 82 & 82 \\
\hline 5 & $\mathrm{Me}$ & 27 & 50 & 50 & 51 \\
\hline 6 & $\mathrm{Ph}$ & 27 & 78 & 80 & 82 \\
\hline 7 & $\mathrm{Me}$ & 28 & 93 & 98 & 93 \\
\hline 8 & $\mathrm{Ph}$ & 28 & 91 & 87 & 98 \\
\hline 9 & $\mathrm{CF}_{3}$ & 25 & - & - & 98 \\
\hline 10 & $\mathrm{CF}_{3}$ & 26 & - & - & 71 \\
\hline 11 & $\mathrm{CF}_{3}$ & 28 & - & - & 98 \\
\hline 12 & $\mathrm{Me}$ & 29 & - & - & 84 \\
\hline 13 & $\mathrm{Me}$ & 30 & - & - & 94 \\
\hline 14 & $\mathrm{Me}$ & 31 & - & - & 0 \\
\hline
\end{tabular}

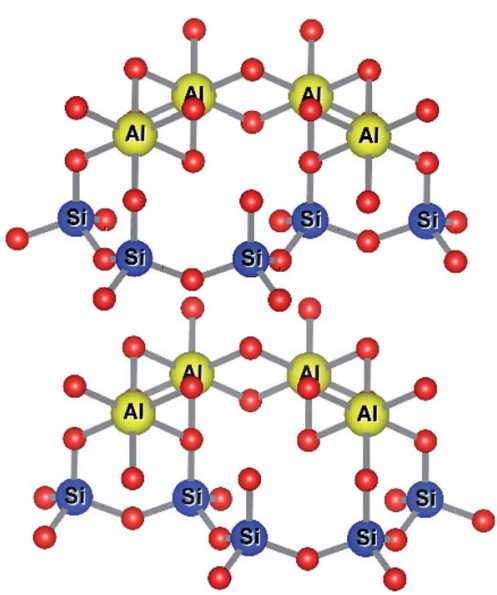

Fig. 7 Structure of kaolinitic clays. ${ }^{103,104}$

introduced, the reaction occurred exclusively at the hydroxyl and no transamidation was reported (entry 9). By virtue of the simple alkyl-spacer which anchors guanidine, the robust TBDMCM catalyst does not leach guanidine. The mechanical stability of the inorganic support materials also ensures easy separation of the solid catalyst.

$\mathrm{Xu}$ et al. have probed the utility of mesoporous CN-FDU-12 in catalysing transesterifications (Table 50). ${ }^{117}$ The surface area and pore volume in CN-FDU-12 are $702 \mathrm{~m}^{2} \mathrm{~g}^{-1}$ and $1.4 \mathrm{~cm}^{3} \mathrm{~g}^{-1}$ respectively. Benzyl alcohol (entry 5) and the heterocyclic furfuryl alcohol (entry 4) afforded comparable conversions to aliphatic alcohols (entries 1-3) demonstrating the substrate scope of this system. Cyclic alcohols proved similarly compatible (entry 3 ). The Lewis base type tertiary $\mathrm{N}$ species are speculated to be the active sites in the catalyst.

Wang and co-workers discovered that $\mathrm{mpg}^{-} \mathrm{C}_{3} \mathrm{~N}_{4}$ is an effective catalyst for both Knoevenagel condensations and transesterifications (Table 51). ${ }^{118}$ The overall performance could be significantly improved if the catalyst was previously treated with base, in the order ${ }^{t} \mathrm{BuOK}>\mathrm{KOH}>\mathrm{K}_{2} \mathrm{CO}_{3}$. Long-chain primary alcohols (entry 4) and hindered cyclic alcohols (entry 5) could both be converted into the corresponding esters, albeit in much higher yields with the former. The heterogeneous catalyst was highly stable and could be reused several times.

Sasidharan and co-workers studied H- $\beta$-zeolites as catalysts for the transesterification of several $\beta$-keto esters (Table 52). ${ }^{119-121}$ The higher acid strength of $\mathrm{H}$ - $\beta$-zeolites, coupled with large pore openings and void spaces, may account for its superior activity. The catalyst was reused three times without loss of activity. Open chain (entries 1-5 and 7-18) and cyclic aliphatic $\beta$-keto esters (entries 6 and 19) afforded higher yields compared to aryl $\beta$-keto esters (entries 7-12), where $15-20 \%$ of starting material was recovered. The bulky nature of these substrates may limit diffusion into the pores of the zeolite catalyst. The catalyst is selective for $\beta$-keto esters with other esters, including $\alpha$-keto esters (entry 20), $\alpha$-halogenated esters (entry 22), unsaturated esters (entry 23) as well as simple esters (entry 21), remaining unreacted. Solvent-free, microwave conditions were examined and furnished high yields of the corresponding products after just 10-15 minutes. This 


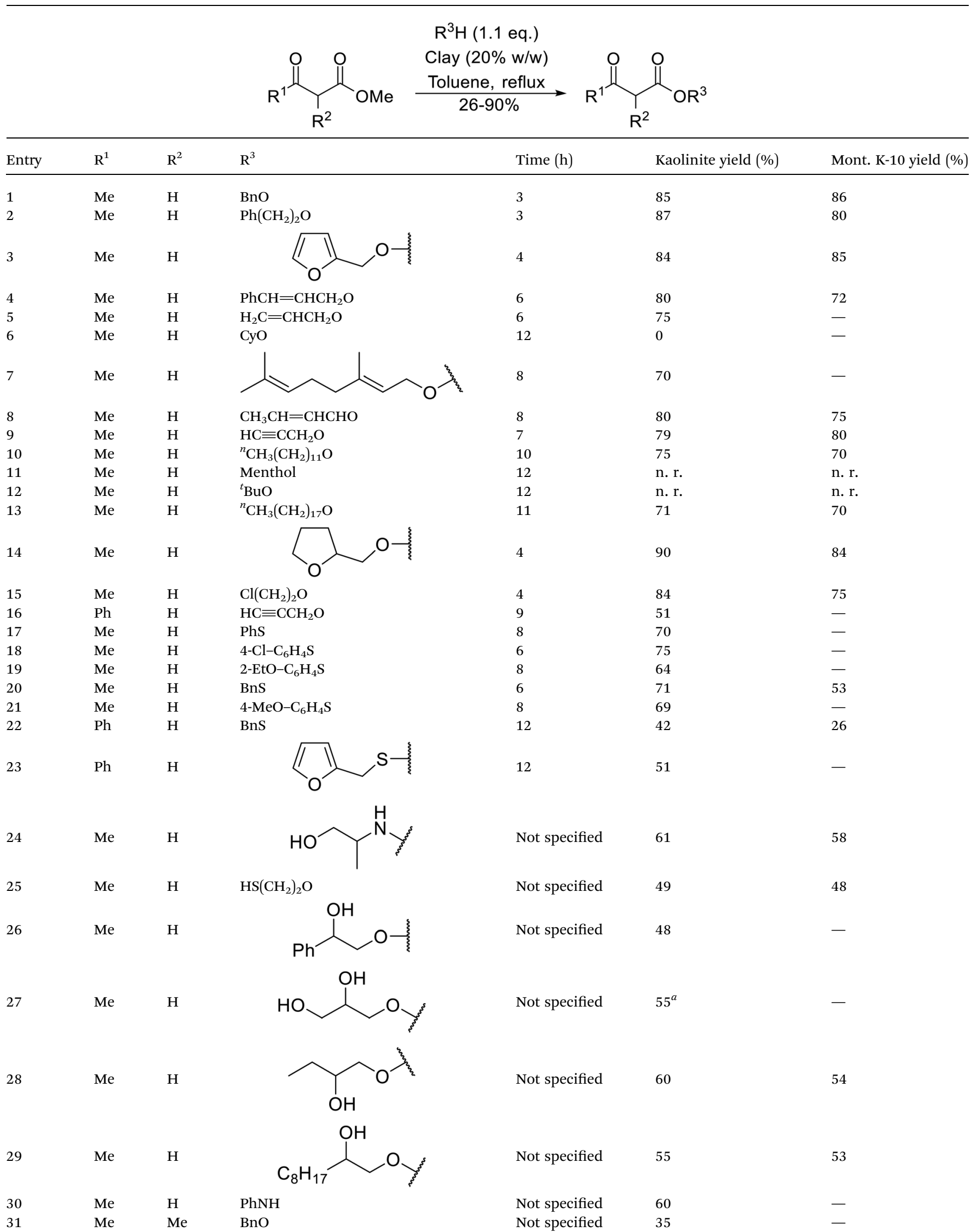


Table 44 (Contd.)

Table 45 Comparison of Envirocat EPZG® and natural clay (NC)

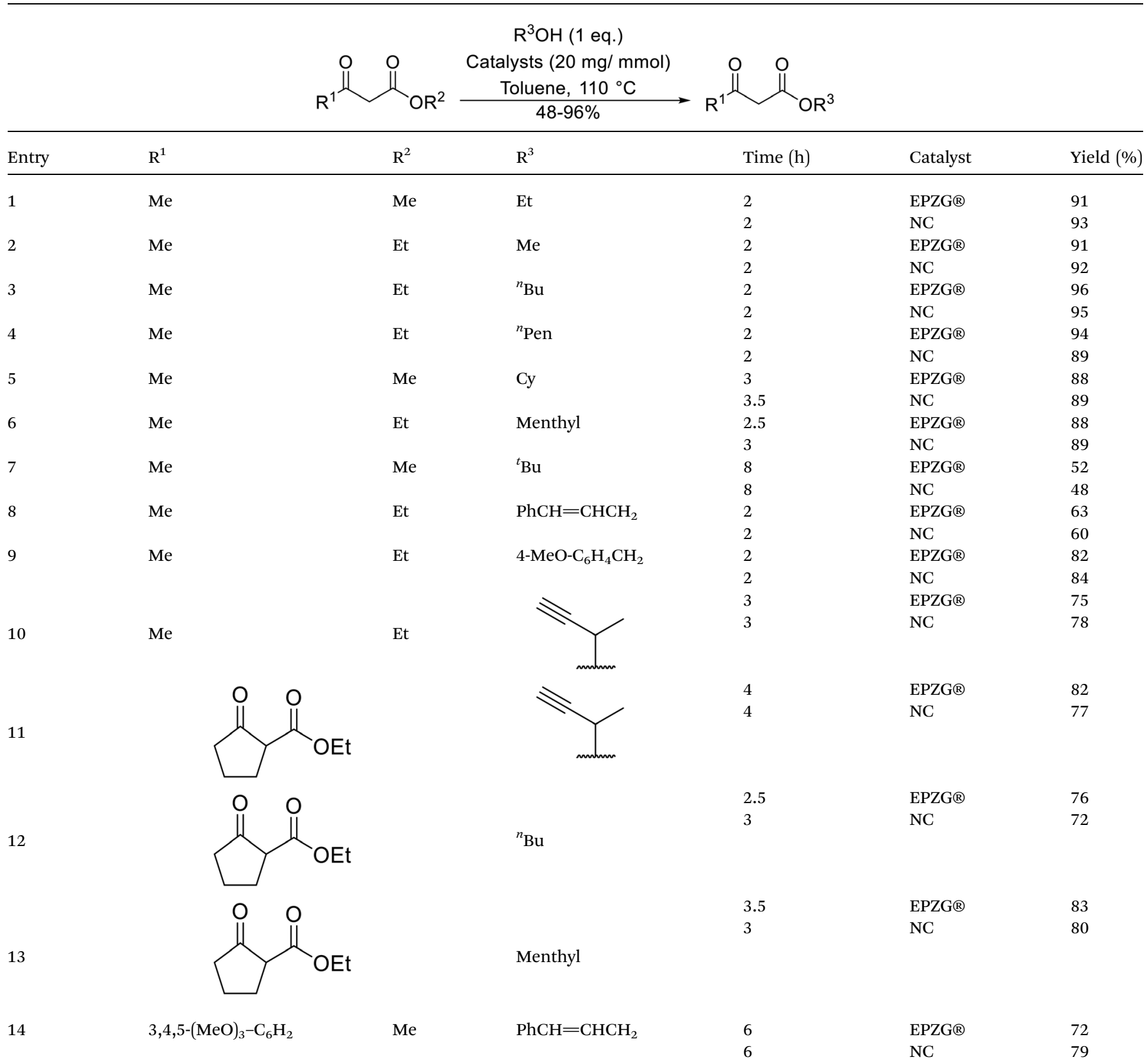


Table 46 [TMBA] NTf catalysis $^{107}$

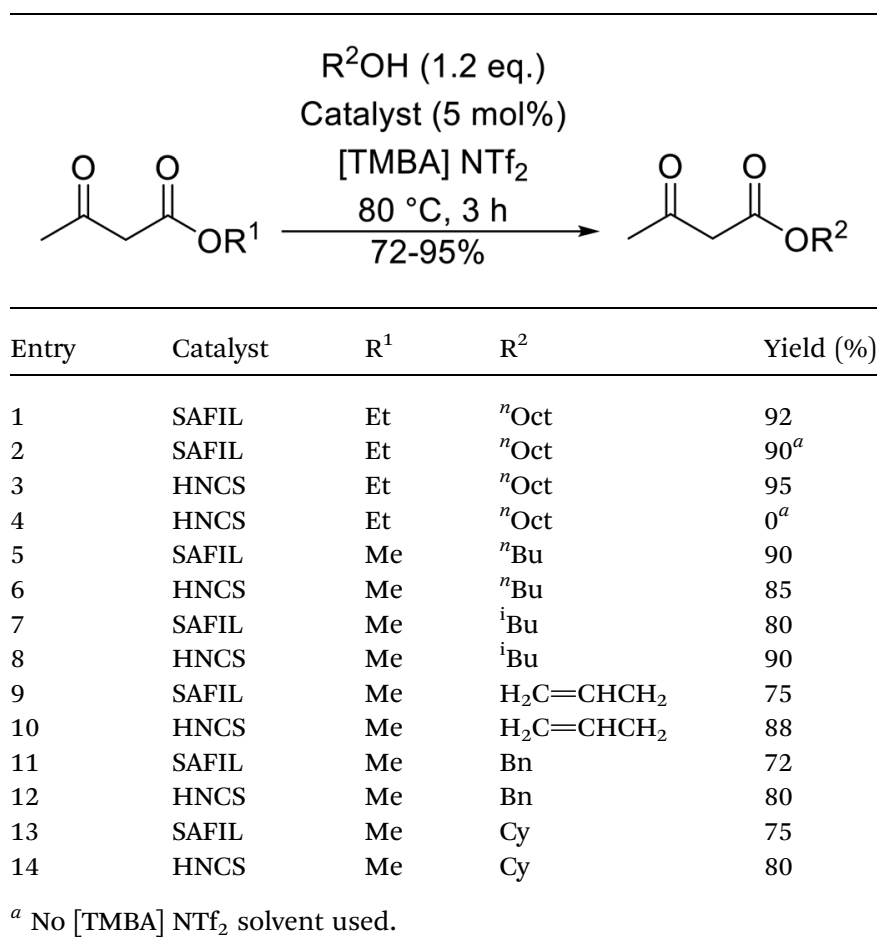

compares favourably with the 8-10 hours required with conventional heating (entries 24-31).

The acidic form of the zeolite ferrierite, namely $\mathrm{H}$-ferrierite (H-FER), is an exceptionally stable and shape selective catalyst for the isomerisation of butane to isobutene. ${ }^{122-124}$ Chavan et al. have reported the transesterification of $\beta$-keto esters catalysed by H-FER under solvent-free conditions (Table 53). ${ }^{125}$ In most cases, 1.2 equivalents of alcohol was sufficient, but for volatile alcohols (entries 3, 6, 7, 11 and 12) a higher loading of 2 equivalents was required. Both primary (entries 3, 5-10 and 1216) and secondary (entries 1, 2, 4 and 11) alcohols were readily esterified. However, tert-butanol did not furnish the corresponding tert-butyl ester. Substitution at the $\alpha$-position hindered the transesterification of ethyl 2-methyl-3oxobutanoate with benzyl alcohol (entry 15). Ethyl 2,2dimethyl-3-oxobutanoate failed to react, due to the absence of an enolisable $\alpha$-proton (entry 16). This zeolite may be reused several times without any loss of activity.

\section{Catalyst-free methodologies}

Depending on the stability of the reactants or products, the presence of a catalyst may not always be well tolerated. This has driven the development of alternative approaches where

Table 47 Silica sol-gel catalysis ${ }^{108,109}$

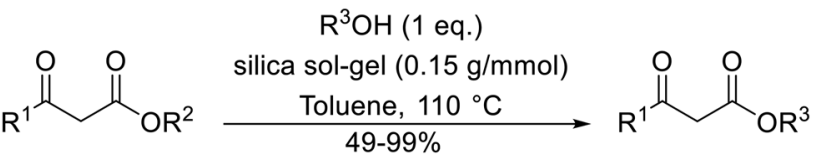

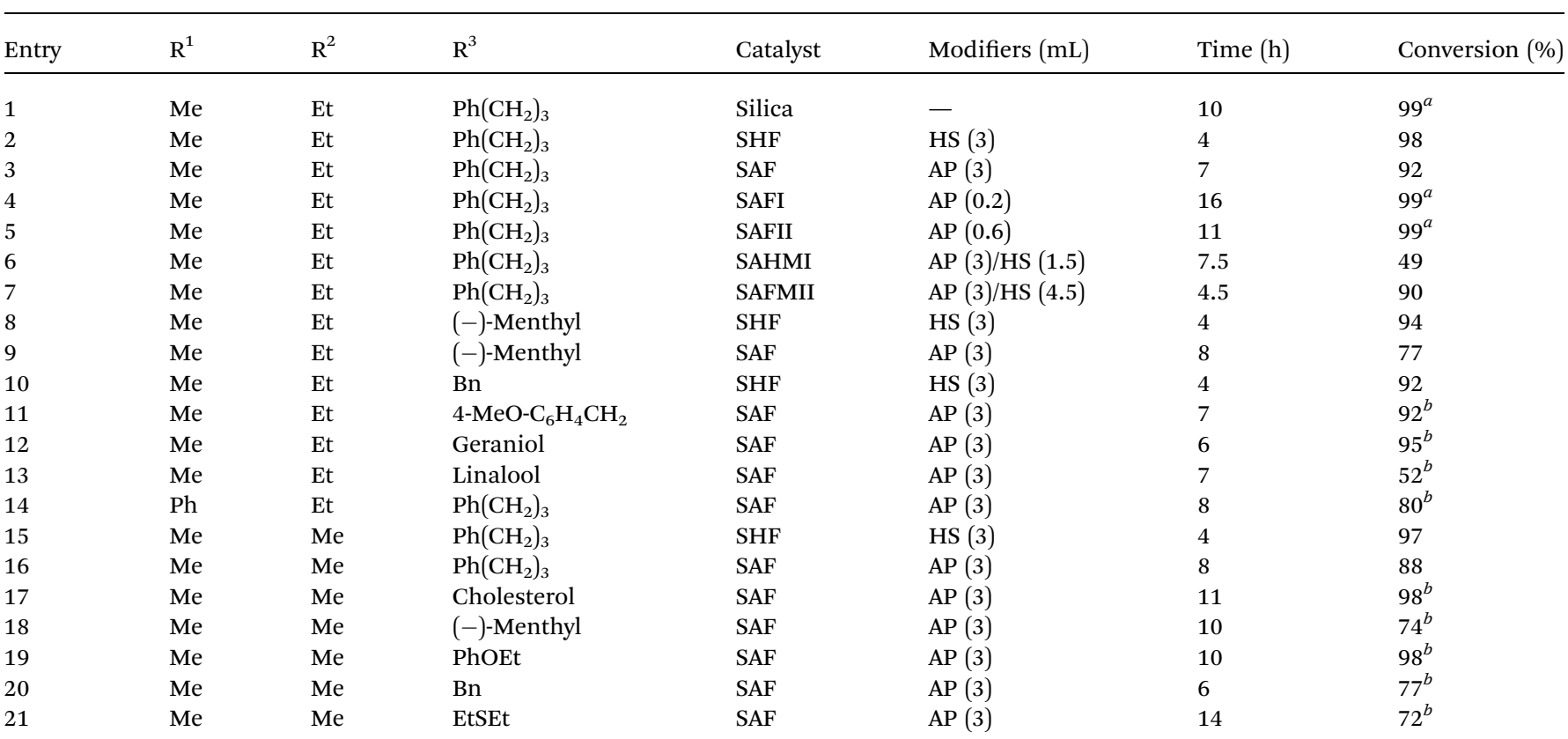

${ }^{a}$ Secondary product detected (bis-3-phenylpropil-ether). ${ }^{b}$ Solvent-free conditions. 


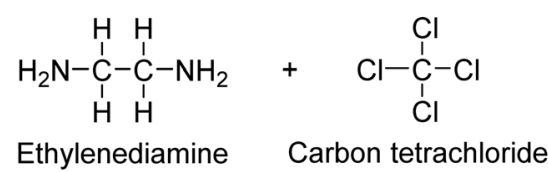

SBA-15

Polymerisation at $90^{\circ} \mathrm{C}$ for $6 \mathrm{~h}$<smiles>CN(C)CCN(C)C(C)(C)C</smiles>

Carbon nitride polmer encapsulated by SBA-15

Carbonisation at $600^{\circ} \mathrm{C}$ for $5 \mathrm{~h}$

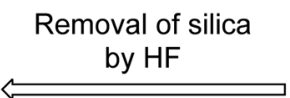

Mesoporous silica- carbon nitride nanocomposites

Scheme 8 Preparation of mesoporous CN using SBA-15. ${ }^{112}$

Table 48 NOMC-550 catalysis $^{115}$

\begin{tabular}{|c|c|c|}
\hline \multirow{2}{*}{$\underbrace{\text { O }}_{\mathbf{5} \text { (1.5 eq.) }}$} & \multirow[t]{2}{*}{$\begin{array}{c}\text { ROH (1 eq.) } \\
\text { NOMC-550 (5 mg/mmol) } \\
\text { Toluene, } 100{ }^{\circ} \mathrm{C}, 6 \mathrm{~h}\end{array}$} & \multirow[t]{2}{*}{$\underbrace{O}_{O R}$} \\
\hline & & \\
\hline Entry & $\mathrm{R}$ & Conversion (\%) \\
\hline 1 & ${ }^{n} \mathrm{Bu}$ & 80 \\
\hline 2 & ${ }^{n}$ Oct & 61 \\
\hline 3 & $\mathrm{Cy}$ & 75 \\
\hline 4 & $\mathrm{Bn}$ & 67 \\
\hline 5 & $\mathrm{PhCH}=\mathrm{CHCH}_{2}$ & 61 \\
\hline 6 & $\mathrm{Ph}\left(\mathrm{CH}_{2}\right)_{2}$ & 58 \\
\hline
\end{tabular}<smiles>CC1O[Si]2(CCCN=C3NCCCN3CC(O)COCC2)OC1C</smiles>

32

Fig. 8 Structure of TBD-MCM

transesterification is promoted by other means, including distillation, molecular sieves or microwave irradiation.

A catalyst-free transesterification of methyl, ethyl and tertbutyl $\beta$-keto esters with primary and secondary propargyl alcohols using a distillation apparatus has been described by Mottet and colleagues (Table 54). ${ }^{\mathbf{1 2 6}}$ This process is not trivial, as traditional acid- and base-catalysed transesterifications with propargyl alcohols produce low yields due to Carroll rearrangement. The transformation of $\mathrm{C}-2$ substituted $\beta$-keto esters (entries 4-12) suggests that a ketene intermediate is likely involved. The absence of catalyst does lead to very slow
Table 49 TBD-MCM catalysis ${ }^{116}$

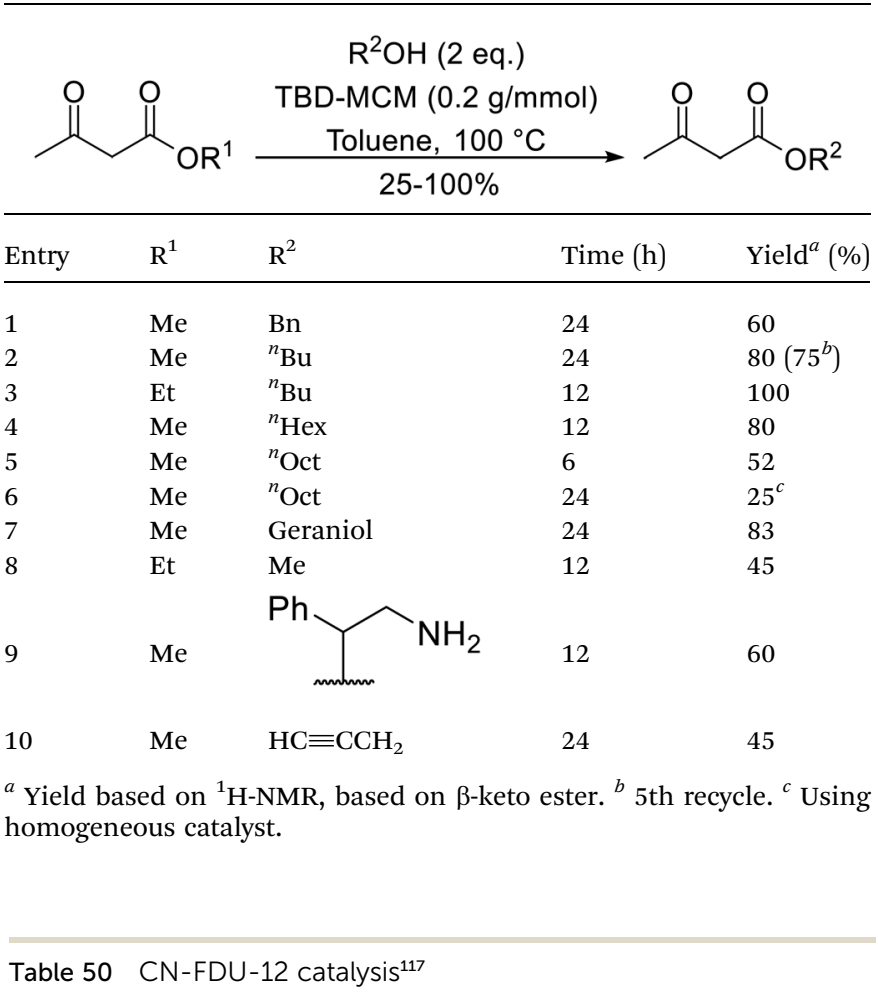

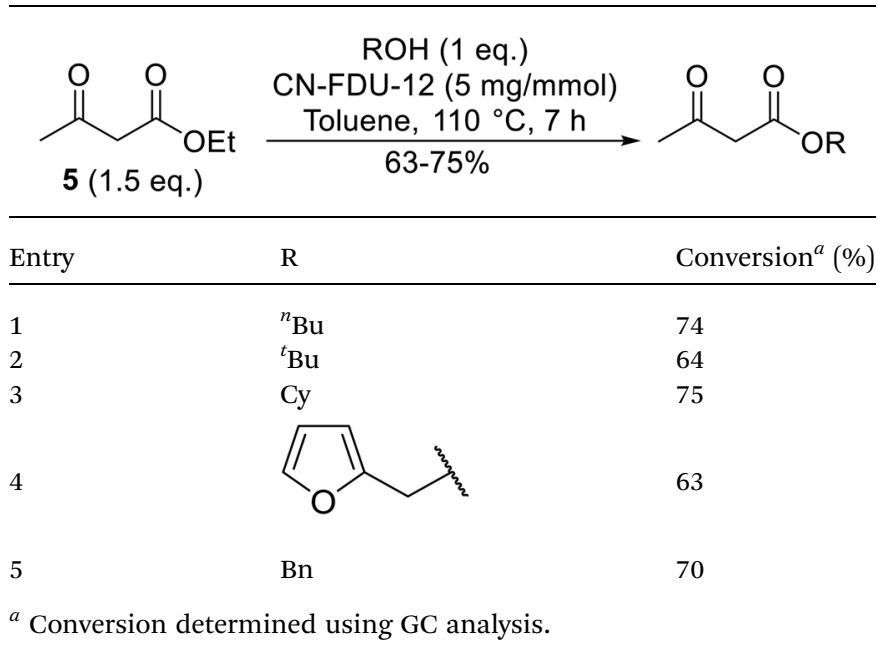


Table $51 \mathrm{Mpg}-\mathrm{C}_{3} \mathrm{~N}_{4}-{ }^{t} \mathrm{Bu}$ catalysis ${ }^{118}$

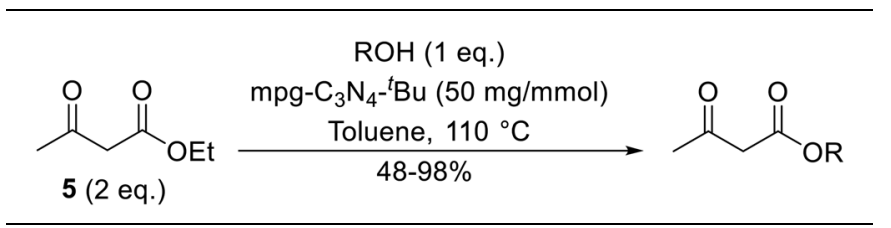

\begin{tabular}{llll}
\hline Entry & $\mathrm{R}$ & Time (h) & Conversion ${ }^{a}(\%)$ \\
\hline 1 & $\mathrm{Bn}$ & 4.5 & 88 \\
2 & $4-\mathrm{MeO}^{-} \mathrm{C}_{6} \mathrm{H}_{4} \mathrm{CH}_{2}$ & 6 & 61 \\
3 & $\mathrm{PhCH}_{2}=\mathrm{CH}_{2}$ & 5 & 90 \\
4 & & 5 & 98 \\
&
\end{tabular}

reactions, with typical reaction times extending from 1 day (entries 1-3) to almost 2 weeks (entries 5 and 7).

Successful catalyst-free transesterifications have been reported on several occasions in the literature, such as the synthesis of $( \pm)$-9-acetoxyfukinanolide and $( \pm)$-velloziolone (Scheme 9).,

Molecular sieves with pore sizes of $4 \AA$ or greater can absorb low molecular weight alcohols such as ethanol and methanol. The removal of these alcohol by-products drives transesterification processes forward (Table 55). Primary (entries 1 and 2), secondary (entries 3-5) and tertiary (entries 6 and 7) alcohols were transesterified in high yields on addition of $4 \AA$ molecular sieves, with reaction times increasing as the steric crowding around the hydroxyl group increased. ${ }^{\mathbf{1 2 7}}$ Tertiary alcohols proved significantly less reactive and the yield of 1adamantanyl acetoacetate was poor (entry 6).

Using a domestic microwave oven, Gianotti et al. successfully transesterified ethyl $\beta$-keto esters with a variety of alcohols

Table $52 \mathrm{H}$ - $\beta$-zeolite catalysis ${ }^{119-121}$

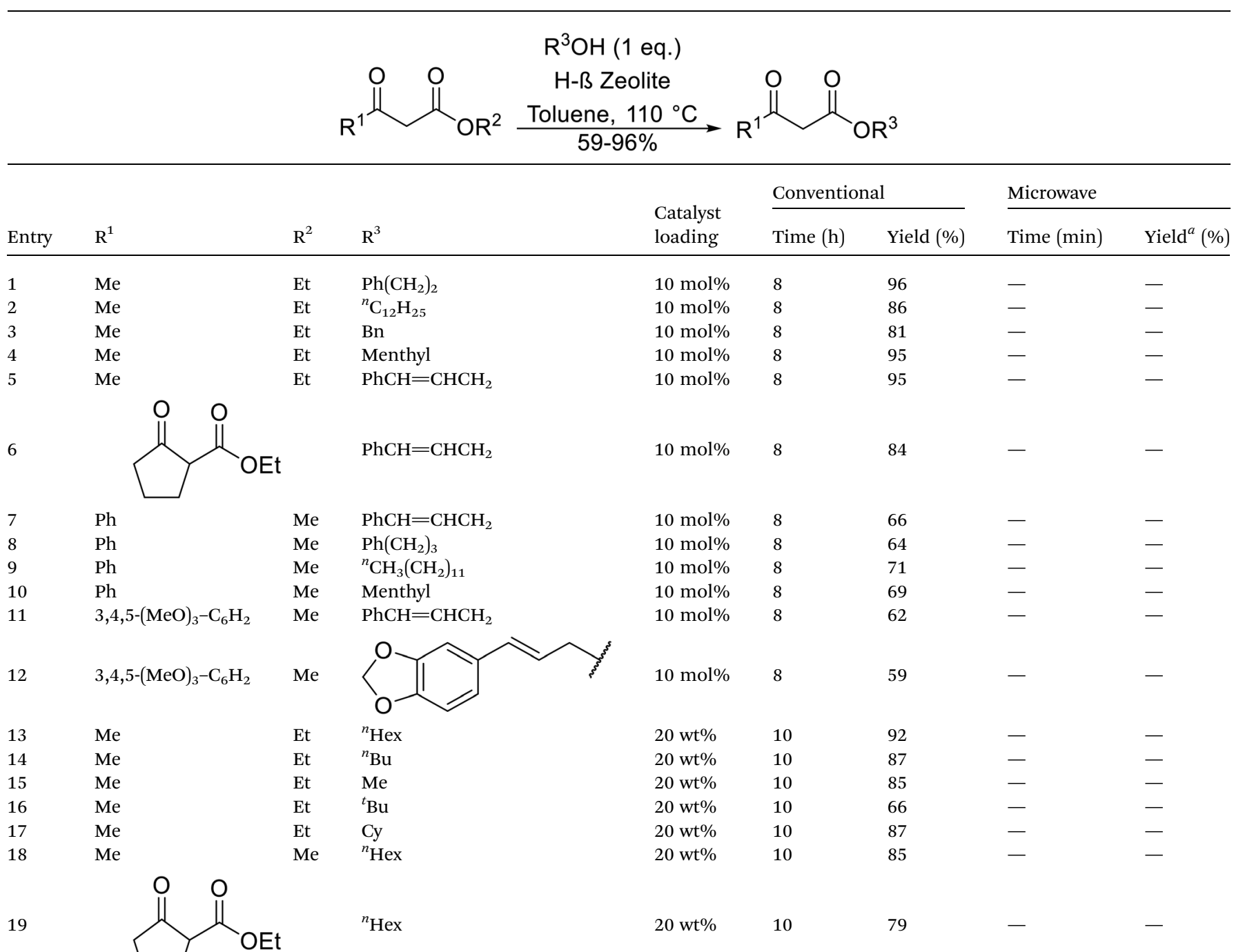


Table 52 (Contd.)

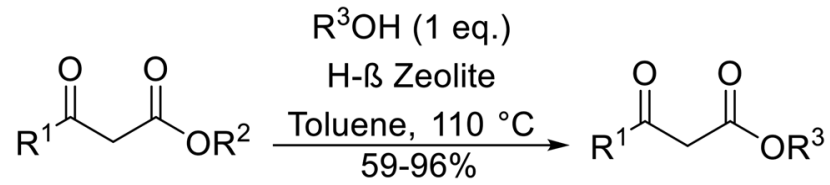

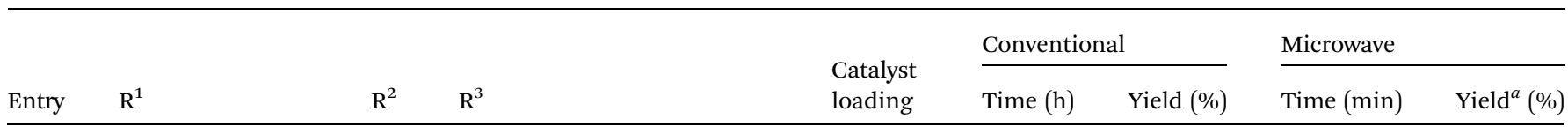

20<smiles>COC(=O)C(C)=O</smiles>

${ }^{n} \mathrm{Hex}$

${ }^{n}$ Hex

${ }^{n}$ Hex

${ }^{n} \mathrm{Hex}$

$\mathrm{Ph}\left(\mathrm{CH}_{2}\right)_{3}$

$\mathrm{PhCH}=\mathrm{CHCH}_{2}$

$\mathrm{Ph}\left(\mathrm{CH}_{2}\right)_{2}$

$\mathrm{EtO}\left(\mathrm{CH}_{2}\right)_{2}$

$\mathrm{Cl}\left(\mathrm{CH}_{2}\right)_{2}$

$\operatorname{Br}\left(\mathrm{CH}_{2}\right)_{2}$

$\mathrm{Ph}\left(\mathrm{CH}_{2}\right)_{2}$

$\mathrm{Ph}\left(\mathrm{CH}_{2}\right)_{3}$

3,4,5-(MeO $)_{3}-\mathrm{C}_{6} \mathrm{H}_{2} \quad$ Et

$20 \mathrm{wt} \%$

10

$20 \mathrm{wt} \% \quad 10$

$20 \mathrm{wt} \% \quad 10$

$20 \mathrm{wt} \% \quad 10$

$\begin{array}{lllll}10 \mathrm{wt} \% & - & - & 10 & 95\end{array}$

$\begin{array}{lllll}10 \mathrm{wt} \% & 8 & 66 & 13 & 78\end{array}$

$\begin{array}{lllll}10 \mathrm{wt} \% & 8 & 64 & 15 & 80\end{array}$

$\begin{array}{lllll}10 \mathrm{wt} \% & - & - & 10 & 72\end{array}$

$\begin{array}{lllll}10 \mathrm{wt} \% & - & - & 11 & 70\end{array}$

$\begin{array}{lllll}10 \mathrm{wt} \% & - & - & 11 & 73\end{array}$

$\begin{array}{lllll}10 \mathrm{wt} \% & - & - & 10 & 80\end{array}$

$10 \mathrm{wt} \%$

$-$

$-$

15

69

${ }^{a} 1: 1$ amount of $\beta$-keto ester and alcohol were mixed and microwaved as a neat mixture with $10 \%$ (w/w of $\beta$-keto ester) of the catalyst.

Table 53 H-FER catalysis ${ }^{125}$

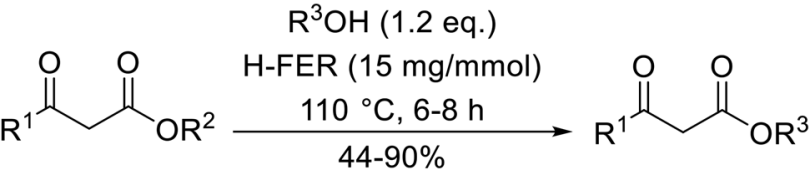

\begin{tabular}{|c|c|c|c|c|c|}
\hline Entry & $\mathrm{R}^{1}$ & $\mathrm{R}^{2}$ & $\mathrm{R}^{3}$ & Alcohol (eq.) & Yie \\
\hline 1 & $\mathrm{Me}$ & $\mathrm{Me}$ & & 1.2 & 72 \\
\hline 2 & $\mathrm{Me}$ & Et & (-)-Menthyl & 1.2 & . \\
\hline 3 & $\mathrm{Me}$ & $\mathrm{Me}$ & $\mathrm{HC} \equiv \mathrm{CCH}_{2}$ & 2 & 1 \\
\hline 4 & $\mathrm{Me}$ & $\mathrm{Me}$ & $\mathrm{Cy}$ & 1.2 & 5 \\
\hline 5 & $\mathrm{Me}$ & $\mathrm{Me}$ & $\mathrm{Bn}$ & 1.2 & 0 \\
\hline 6 & $\mathrm{Me}$ & $\mathrm{Me}$ & $\mathrm{H}_{2} \mathrm{C}=\mathrm{CHCH}_{2}$ & 2 & 5 \\
\hline 7 & $\mathrm{Me}$ & $\mathrm{Me}$ & ${ }^{\mathrm{i}} \mathrm{Bu}$ & 2 & 84 \\
\hline 8 & $\mathrm{Me}$ & $\mathrm{Me}$ & ${ }^{n}$ Dec & 1.2 & \\
\hline
\end{tabular}




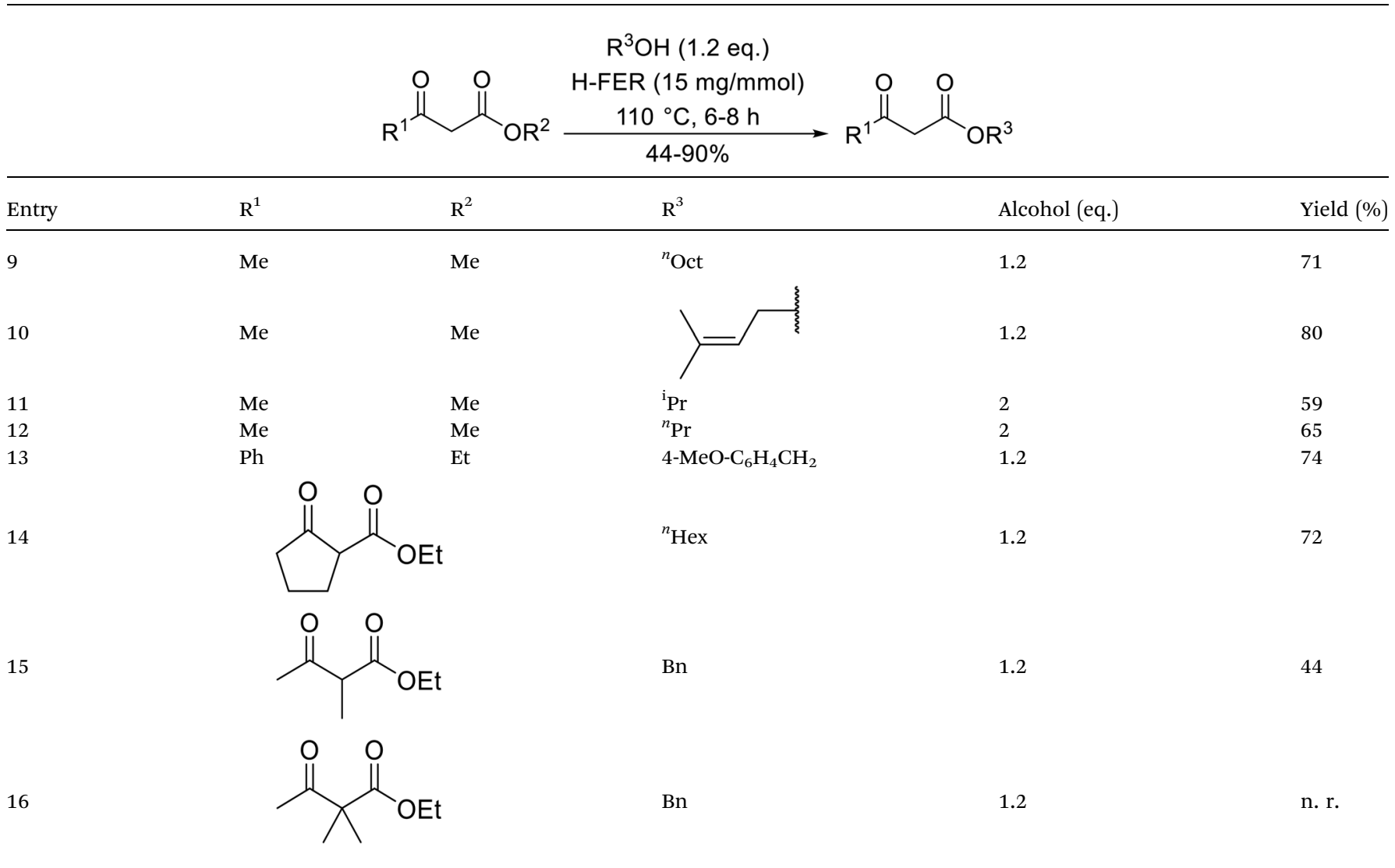

(Table 56). ${ }^{128}$ The presence of a TBDMS protecting group did not interfere with the expected outcome (entry 1-5). Only enolisable $\beta$-keto esters were found to react, suggesting that the reaction proceeds via an enol intermediate in this instance. Both aromatic (entries 2, 4, 7 and 9) and aliphatic alcohols (entries 1, $3,5,6,8$ and 10) furnished the corresponding esters in good to excellent yields. The only exception was the transesterification of ethyl acetoacetate with diphenylmethanol, which resulted in a $62 \%$ yield (entry 9). Employing tert-butyldimethylsilanol afforded a similar yield of $60 \%$ (entry 11 ).

A catalyst-free, one-pot synthesis of dihydropyrimidinones was developed by Darma Rao and co-workers. ${ }^{129,130}$ This methodology involved the in situ generation of $\beta$-keto esters via transesterification followed by a Biginelli reaction with arylaldehyde and urea at $110^{\circ} \mathrm{C}$ (Scheme 10). The best results were obtained when the $\beta$-keto ester, arylaldehyde, urea and propargyl alcohol were used in a $1: 1: 1.2: 1.5$ ratio. ESI-MS analysis confirmed the presence of the transesterified propargyl- $\beta$-keto ester product after ten minutes, the dihydropyrimidinone product and tert-butyl $\beta$-keto ester after 1 hour, and finally the desired dihydropyrimidinones after three hours. This one-pot preparation followed two main pathways: either transesterification followed by Biginelli reaction or vice versa. When the same conditions were applied to methyl, ethyl or isobutyl $\beta$ - keto esters, the corresponding transesterified dihydropyrimidinones were obtained as expected.

The scope of this transesterification procedure was investigated across a range of alcohols (Table 57). In general, yields were good to excellent, but tertiary alcohols (entry 7) and unsaturated aliphatic alcohols (entries 14 and 15) were associated with a noticeable reduction in yields. The presence of amine (entry 5) or ether (entries 9 and 12) functional groups was tolerated under these conditions.

The semi-synthesis of paclitaxel from 10-deacetylbaccatin III involves a key transesterification reaction. With this in mind, Mandai et al. developed a catalyst- and solvent-free methodology and expanded its scope to include various $\beta$-keto esters (Table 58). ${ }^{2}$ A large excess (20 equivalents) of the $\beta$-keto ester, heated to $90{ }^{\circ} \mathrm{C}$ for 24 hours, generated the target in $82 \%$ yield (entry 1 ). The reaction was greatly accelerated by continuous removal of ethanol under reduced pressure (entry 2). Transesterification proceeded at a reasonable rate at $70{ }^{\circ} \mathrm{C}$ (entry 3) but very slowly at $50{ }^{\circ} \mathrm{C}$ (entry 4 ) even under reduced pressure. Reducing the equivalents of $\beta$-keto ester from 20 to 5 led to only a slight reduction in yield (entry 5). However, a reduction to 2 equivalents caused a sharp decrease in yield (entry 6). In cases where $\mathrm{R}^{2}$ is aromatic, the reactivity or yields were not affected (entries 9-14). Cyclic and acyclic substituents were also well 
Table 54 Catalyst-free conditions ${ }^{126}$

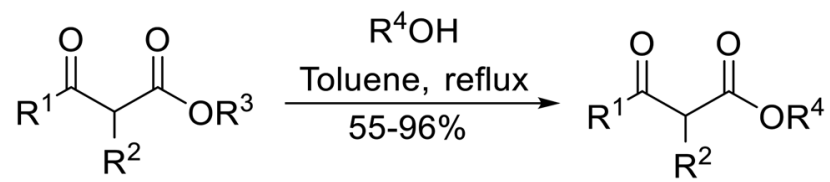

\begin{tabular}{|c|c|c|c|c|c|c|c|}
\hline Entry & $\mathrm{R}^{1}$ & $\mathrm{R}^{2}$ & $\mathrm{R}^{3}$ & $\mathrm{R}^{4}$ & Alcohol (eq.) & Time (days) & Yield \\
\hline 1 & ${ }^{n} \operatorname{Pr}$ & $\mathrm{H}$ & Et & $\mathrm{HC} \equiv \mathrm{CCH}_{2}$ & 5 & 1 & 91 \\
\hline 2 & ${ }^{n} \operatorname{Pr}$ & $\mathrm{H}$ & Et & $\mathrm{CH}_{3} \mathrm{C} \equiv \mathrm{CCH}_{2}$ & 1.5 & 1 & 94 \\
\hline 3 & $\mathrm{Ph}$ & $\mathrm{H}$ & Et & $\mathrm{HC} \equiv \mathrm{CCH}_{2}$ & 5 & 1 & 96 \\
\hline 4 & Me & $\mathrm{CHCH}=\mathrm{CH}_{2}$ & $\mathrm{Me}$ & $\mathrm{HC} \equiv \mathrm{CCH}_{2}$ & 5 & 10 & 70 \\
\hline 5 & Me & $\mathrm{PhCH}_{2}$ & Me & $\mathrm{HC} \equiv \mathrm{CCH}_{2}$ & 5 & 12 & 69 \\
\hline 6 & Me & $\mathrm{PhCH}_{2}$ & $\mathrm{Me}$ & $\mathrm{HC} \equiv \mathrm{CCH}_{2}$ & 5 & 6 & 55 \\
\hline 7 & Me & ${ }^{\mathrm{i}} \mathrm{Pr}$ & ${ }^{t} \mathrm{Bu}$ & $\mathrm{HC} \equiv \mathrm{CCH}_{2}$ & 5 & 12 & 79 \\
\hline 8 & & & & $\mathrm{HC} \equiv \mathrm{CCH}_{2}$ & 5 & 4 & 59 \\
\hline 9 & & & & $\mathrm{HC} \equiv \mathrm{CCH}_{2}$ & 5 & 0.8 & 86 \\
\hline 10 & & & & $\mathrm{HC} \equiv \mathrm{CCH}_{2}$ & 5 & 1 & 90 \\
\hline 11 & Me & $\mathrm{CH}_{2} \mathrm{Ph}$ & Me & $\mathrm{HC} \equiv \mathrm{CCH}(\mathrm{Ph})$ & 1.2 & 10 & 85 \\
\hline 12 & $\mathrm{Me}$ & $\mathrm{CH}_{2} \mathrm{Ph}$ & $\mathrm{Me}$ & $\mathrm{HC} \equiv \mathrm{CCH}\left({ }^{n} \mathrm{Pe}\right)$ & 1.2 & 10 & 83 \\
\hline
\end{tabular}

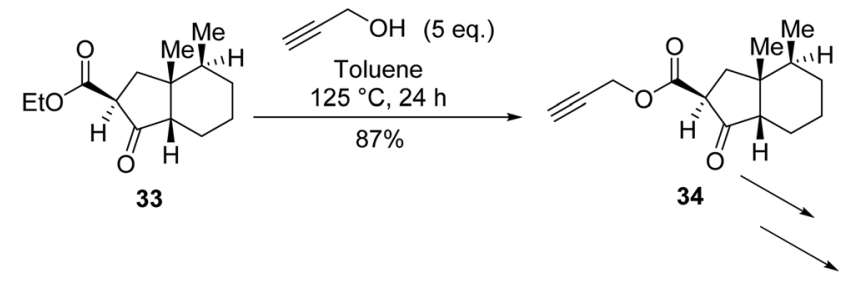

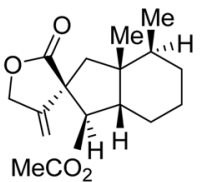

( \pm -9-Acetoxyfukinanolide (2)
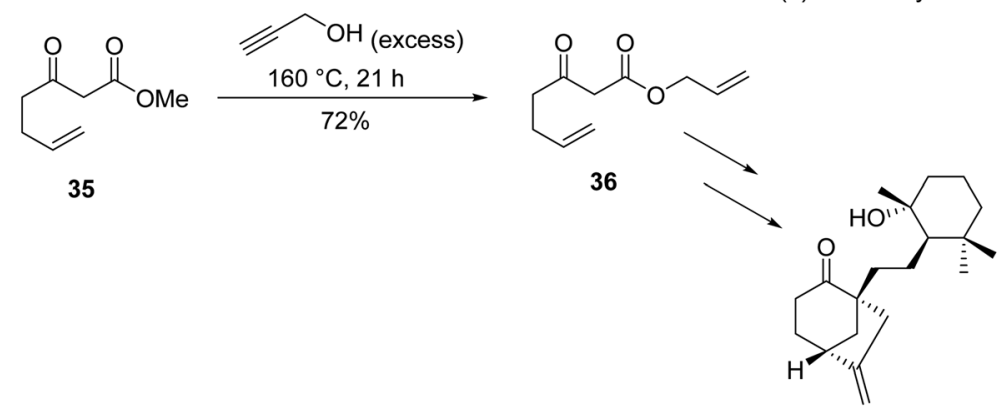

$( \pm)$-Velloziolone (4)

Scheme 9 Synthesis of $( \pm)$-9-acetoxyfukinanolide and $( \pm)$-velloziolone. 
Table 55 Impact of 4 A molecular sieves ${ }^{127}$

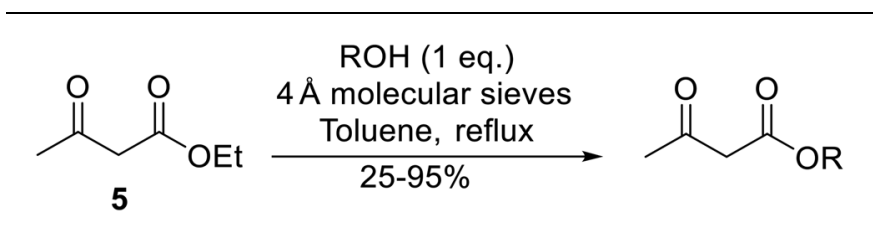

\begin{tabular}{llll}
\hline Entry & $\mathrm{R}$ & Time $(\mathrm{h})$ & Yield (\%) \\
\hline 1 & ${ }^{n} \mathrm{Hex}$ & 4 & 95 \\
2 & ${ }^{n} \mathrm{CH}_{3}\left(\mathrm{CH}_{2}\right)_{11}$ & 5 & 93 \\
3 & Cy & 9.5 & 87 \\
4 & Menthyl & 12 & 92 \\
5 & Borneol & 16 & 78 \\
6 & 1-Adamantanol & 24 & 25 \\
7 & 2-Methyl-2-butanol & 9 & 90
\end{tabular}

tolerated (entries 14-16). Methyl-substituted ethyl benzoylacetate reacted sluggishly to yield only $20 \%$ of product (entry 19 ).

Chadha and co-workers discovered that reaction of $\beta$-keto esters with polyols under microwave irradiation afforded the corresponding monotransester in good to excellent yields (Table 59). ${ }^{\mathbf{1 3 1}}$ Subsequent crosslinking led to the accumulation of the corresponding diester as a minor product. A molar ratio of $1: 5 \beta$-keto ester to polyol minimised the formation of the unwanted diester. The efficient absorption of microwave energy by the polar reactants saw full conversions in under 10 minutes in all cases. An increase in chain length was associated with longer reaction times and lower yields (entries 9-11). The unsaturated diol 1,4-butenediol also underwent selective mono-

Table 56 Microwave heating ${ }^{128}$

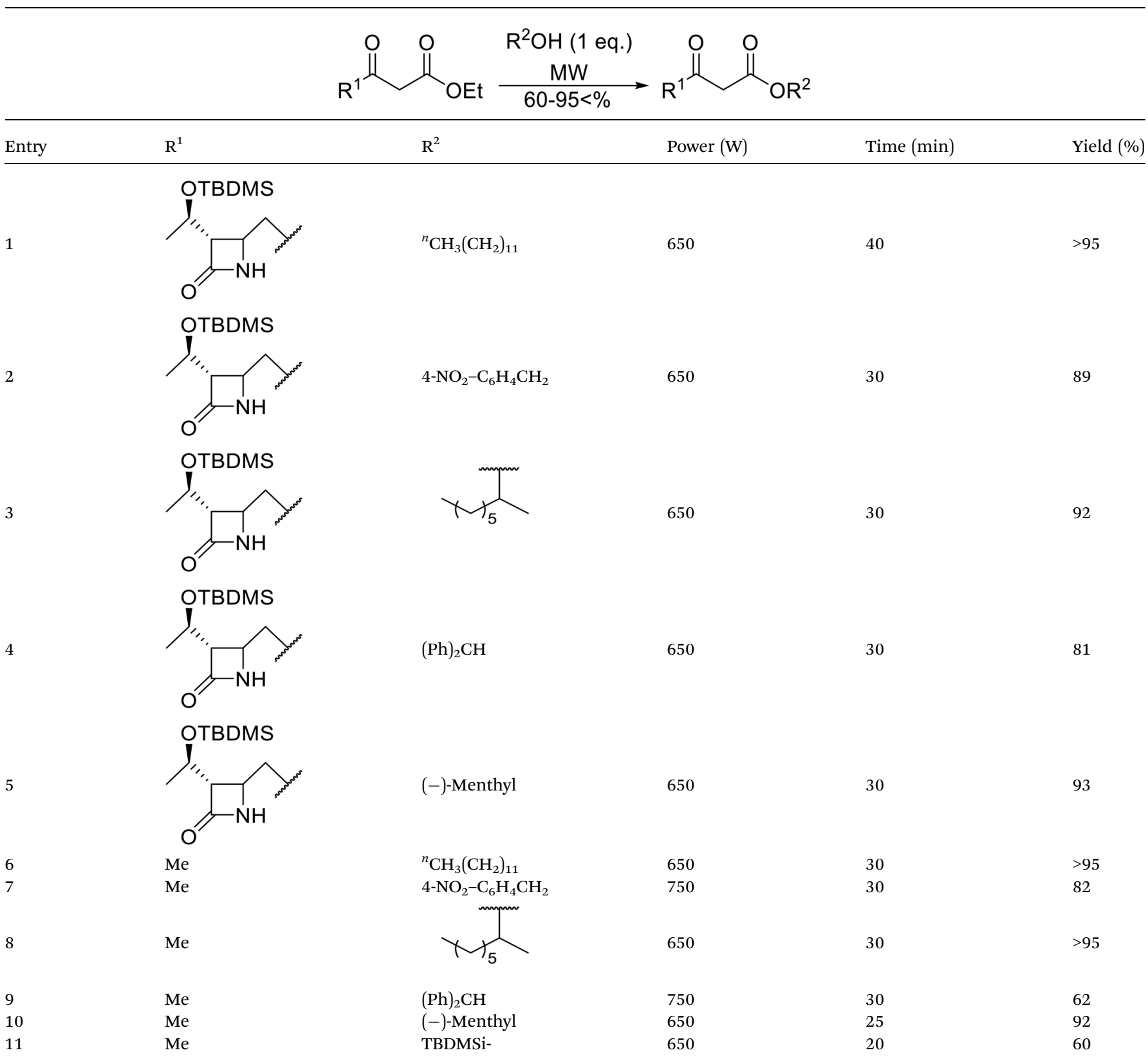




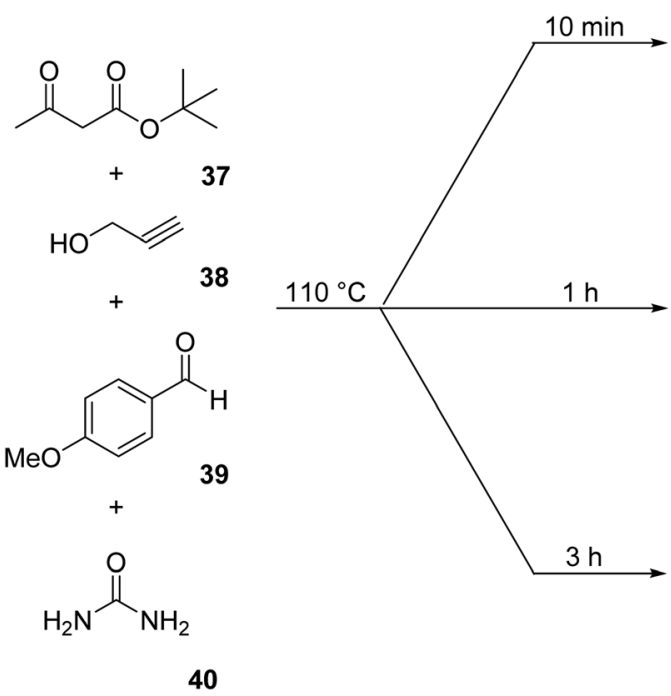<smiles>C#CCOC(=O)CC(C)=O</smiles><smiles>C#CCOC(=O)C1=C(C)NC(=O)NC1c1ccc(OC)cc1</smiles><smiles>C#CCOC(=O)C1=C(C)NC(=O)NC1c1ccc(OC)cc1</smiles>

Scheme 10 Pathways to dihydropyrimidin-2(1H)-one C5 ester derivatives. ${ }^{129}$

Table 57 Transesterification under solvent-free, catalyst-free conditions $^{130}$

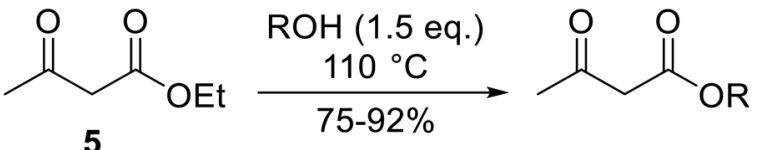

\begin{tabular}{|c|c|c|c|}
\hline Entry & $\mathrm{R}$ & Time (h) & Yield (\%) \\
\hline 1 & Et & 3 & 92 \\
\hline 2 & ${ }^{\mathrm{i}} \mathrm{Bu}$ & 3 & 90 \\
\hline 3 & Et & 3 & 85 \\
\hline 4 & ${ }^{n}$ Oct & 3 & 85 \\
\hline 5 & $\mathrm{Me}_{2} \mathrm{~N}\left(\mathrm{CH}_{2}\right)_{2}$ & 3 & 90 \\
\hline 6 & $\mathrm{Ph}$ & 3 & 85 \\
\hline 7 & ${ }^{t} \mathrm{Bu}$ & 5.5 & 60 \\
\hline 8 & $\mathrm{Bn}$ & 3.5 & 88 \\
\hline 9 & $4-\mathrm{MeO}-\mathrm{C}_{6} \mathrm{H}_{4} \mathrm{CH}_{2}$ & 3 & 90 \\
\hline 10 & 4-Cl- $\mathrm{C}_{6} \mathrm{H}_{4} \mathrm{CH}_{2}$ & 4 & 85 \\
\hline 11 & $\mathrm{Ph}\left(\mathrm{CH}_{2}\right)_{2}$ & 3 & 83 \\
\hline 12 & & 4 & 80 \\
\hline 13 & $\mathrm{CH}_{2}=\mathrm{CHCH}_{2}$ & 3 & 80 \\
\hline 14 & & 4 & 76 \\
\hline 15 & $\mathrm{HC} \equiv \mathrm{CCH}_{2}$ & 3 & 75 \\
\hline
\end{tabular}

transesterification (entry 19). Accordingly, this method may be suitable for the selective mono-transesterification of polyols.

\section{Miscellaneous methods}

Superacids are more acidic than sulfuric acid and have a proven track record in organic transformations. ${ }^{\mathbf{1 3 2}}$ Chavan et al. have pioneered the use of the sulfonated stannous oxide, a solid super acid, for transesterification reactions (Table 60). ${ }^{\mathbf{1 3 3}}$ This catalyst is selective for both $\beta$-keto esters (entries 1-6 and 8-10) and $\gamma$-keto esters (entry 7 ). However, $\gamma$-keto esters did require longer reaction times and returned lower yields. Transesterification of tertiary alcohols generally proceeded in lower yields (entries 9 and 10). Some of the limitations of this catalyst includes its high cost and difficulty of preparation.

Amberlyst-15 is an acidic ion exchange resin often employed in organic synthesis (Table 61). ${ }^{\mathbf{1 3 4 - 1 3 7}}$ Amberlyst-15 successfully catalysed the transesterification of primary (entries 1-7 and 1012), secondary (entries 8 and 9) and allylic alcohols (entry 10). ${ }^{138}$ Both $\beta$-ketoesters (entries 1-11) and $\gamma$-ketoesters (entry 12) were also transesterified. The conversion of $N$-(2-hydroxyethyl) phthalimide to 2-phthalimidoethyl acetoacetate ester (entry 1) is especially noteworthy, as the product is an important building block for the preparation of 1,4-dihydropyridine derivatives, which are calcium channel blockers. When mercaptoethanol was introduced, an equimolar amount of the thioester and ester products were recovered in good yields (entry 11).

Sodium borohydride is commonly employed for the reduction of carbonyls and imines, but not esters. Padhi and Chadha 


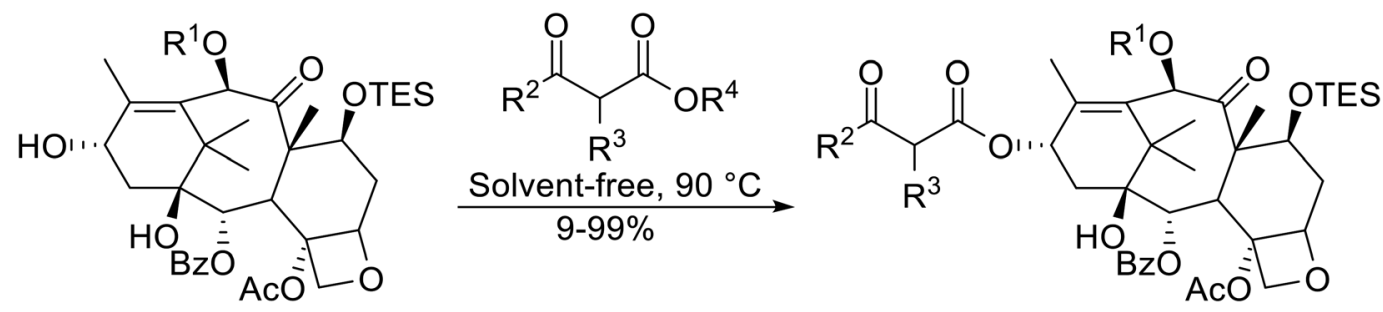

\begin{tabular}{|c|c|c|c|c|c|c|c|c|}
\hline Entry & $\mathrm{R}^{1}$ & $\mathrm{R}^{2}$ & $\mathrm{R}^{3}$ & $\mathrm{R}^{4}$ & $\begin{array}{l}\beta \text {-Keto } \\
\text { ester eq. }\end{array}$ & Pressure (mmHg) & Time (h) & Yield (\%) \\
\hline 1 & $\mathrm{Cbz}$ & $\mathrm{Ph}$ & $\mathrm{H}$ & Et & 20 & 760 & 24 & $82\left(14^{a}\right)$ \\
\hline $3^{b}$ & $\mathrm{Cbz}$ & $\mathrm{Ph}$ & $\mathrm{H}$ & $\mathrm{Et}$ & 20 & $<1$ & 27 & $90\left(5^{a}\right)$ \\
\hline $4^{c}$ & $\mathrm{Cbz}$ & $\mathrm{Ph}$ & $\mathrm{H}$ & Et & 20 & $<1$ & 21 & $9\left(90^{a}\right)$ \\
\hline 5 & $\mathrm{Cbz}$ & $\mathrm{Ph}$ & $\mathrm{H}$ & Et & 5 & 20 & 10 & 94 \\
\hline 8 & Alloc & $\mathrm{Ph}$ & $\mathrm{H}$ & Et & 20 & $<1$ & 3 & 96 \\
\hline 9 & $\mathrm{Cbz}$ & $4-\mathrm{MeO}-\mathrm{C}_{6} \mathrm{H}_{4}$ & $\mathrm{H}$ & $\mathrm{Me}$ & 10 & 20 & 7 & 99 \\
\hline 10 & $\mathrm{Cbz}$ & $3-\mathrm{F}-\mathrm{C}_{6} \mathrm{H}_{4}$ & $\mathrm{H}$ & $\mathrm{Me}$ & 10 & 20 & 6 & 88 \\
\hline 11 & $\mathrm{Cbz}$ & $2-\mathrm{F}-\mathrm{C}_{6} \mathrm{H}_{4}$ & $\mathrm{H}$ & $\mathrm{Me}$ & 10 & 20 & 6 & 92 \\
\hline 12 & $\mathrm{Cbz}$ & $4-\mathrm{F}-\mathrm{C}_{6} \mathrm{H}_{4}$ & $\mathrm{H}$ & $\mathrm{Me}$ & 10 & 20 & 6 & 94 \\
\hline 13 & $\mathrm{Cbz}$ & $3-\mathrm{CF}_{3}-\mathrm{C}_{6} \mathrm{H}_{4}$ & $\mathrm{H}$ & $\mathrm{Me}$ & 10 & 20 & 6 & 90 \\
\hline 17 & $\mathrm{Cbz}$ & ${ }^{n} \mathrm{CH}_{3}\left(\mathrm{CH}_{2}\right)_{8}$ & $\mathrm{H}$ & $\mathrm{Me}$ & 10 & 20 & 6 & 95 \\
\hline 18 & $\mathrm{Cbz}$ & & $\mathrm{C}$ & & $20^{a}$ & 20 & 5 & 93 \\
\hline 19 & $\mathrm{Cbz}$ & $\mathrm{Ph}$ & $\mathrm{Me}$ & $\mathrm{Me}$ & 20 & 20 & 25 & $20^{b}$ \\
\hline
\end{tabular}

have developed a room temperature, one-pot reduction/ transesterification of $\beta$-keto esters using sodium borohydride (Table 62). ${ }^{139}$ Kinetic studies established that the reduction step precedes transesterification. When dissolved in an alcohol, sodium borohydride forms a $\mathrm{Na}^{+} \mathrm{B}^{-}(\mathrm{H})_{3}(\mathrm{OR})_{1}$ complex. ${ }^{140,141}$ The active hydride in this complex is responsible for the reduction of the carbonyl group. Transesterification of $\beta$-hydroxy esters is difficult due to the presence of the acid/alkali sensitive hydroxyl, and often necessitates exotic reagents or prolonged reaction times. ${ }^{142-144}$ Employing isopropanol led to a low $45 \%$ yield (entry 4). Propargyl alcohol also resulted in a poor yield of $25 \%$ (entry 15). These low yields are likely due to the poor solubility of sodium borohydride in these alcohols, leading to limited formation of the key alkoxy borate complex. Sodium borohydride-mediated reduction/transesterification is unique to $\beta$-keto esters. With $\alpha$ - and $\gamma$-keto esters, only the corresponding hydroxy esters were recovered. A similar reduction/ transesterification reaction of $\alpha$-keto esters employing a combination of sodium borohydride and cerium trichloride has been reported. ${ }^{145}$

Yadav et al. discovered that triphenylphosphine facilitates the transesterification of $\beta$-keto esters (Table 63). ${ }^{146}$ In all cases, the reactions reached completion within 6-8 hours. Challenging substrates, such as propargyl alcohol (entry 1), sterically hindered menthol (entry 5) and prenol (entry 9), reacted readily to give products in excellent yields. In the case of heptyl alcohol, transesterification of an aromatic ester (entry 3) was faster than for an aliphatic ester (entry 14). A similar trend was noted for decenyl alcohol (entry 4 vs. 15). The reaction of benzyl alcohol with a cyclic ester (entry 11) was slower than with an aliphatic ester (entry 10). This confirms that aromatic esters are more reactive than aliphatic esters, which in turn are more reactive than cyclic esters. 
Table 59 Microwave-mediated transesterification of polyols ${ }^{131}$

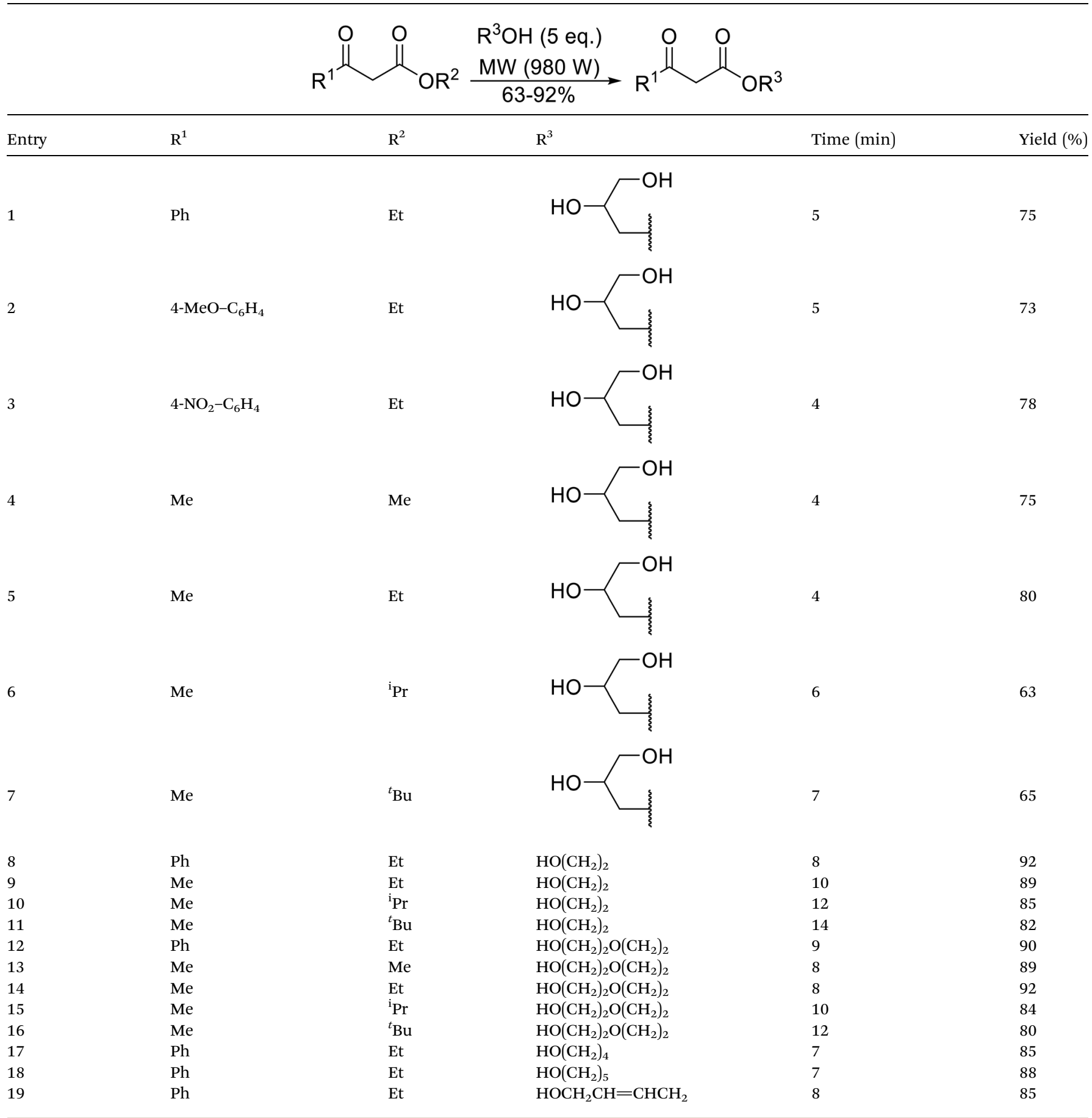

In recent years, the application of ionic liquids to organic transformations has gained considerable interest. ${ }^{\mathbf{1 4 7}}$ Bhanage and co-workers investigated $\mathrm{N}$-methyl-2-pyrrolidone hydrogen sulfate $\left([\mathrm{NMP}]^{+} \mathrm{HSO}_{4}{ }^{-}\right)$as an efficient and reusable catalyst for the transesterification of $\beta$-ketoesters. ${ }^{\mathbf{1 4 8}}$ This ionic liquid has several important advantages over other systems including high catalytic activity. Additionally, $N$-methyl-2-pyrrolidone is more economical and accessible than other imidazolium/pyridinium counterparts. $\beta$-Ketoesters were smoothly transesterified in high yields with easy separation of the ionic liquid and the products (Table 64). Transesterification of methyl acetoacetate with aliphatic alcohols furnished yields of between $74 \%$ and $91 \%$ 


\begin{tabular}{llll}
\hline \\
Entry
\end{tabular}

(entries 1-7). Similar results were obtained with ethyl acetoacetate (entries 12-14). [NMP] ${ }^{+} \mathrm{HSO}_{4}{ }^{-}$produced good yields with various unsaturated alcohols (entries 9-11 and 16) and with no evidence of Carroll rearrangement. Four successive runs with the recycled catalyst saw only a slight decrease in yields.

1-Propyl-3-methylimidazole chloride $\left(\left[\mathrm{C}_{3} \mathrm{MIm}\right] \mathrm{Cl}\right)$ in sulfamic acid has been studied as a recyclable catalytic medium for the transesterification of methyl acetoacetate (Table 65). ${ }^{\mathbf{1 4 9}}$ These conditions were compatible with a wide range of structurally diverse substrates including aliphatic (entries 1-4), cyclic (entry 5), unsaturated (entries 6 and 7), aromatic (entries 8 and 9) and sterically crowded (entry 3) alcohols. This catalyst system was reused five times with only a slight decrease in yield noted (entry 1). A disadvantage of this approach is the requirement for large quantities of the ionic liquid (10 $\mathrm{g}$ ionic liquid for $1 \mathrm{~g}$ sulfamic acid).

Weber et al. have recently reported the synthesis of long chain acetoacetates via sulfamic acid catalysis under solventfree conditions (Table 66). ${ }^{150}$ Using microwave irradiation, the reaction time was reduced from 6 hours to 13 minutes. The yields obtained via conventional heating or microwave irradiation were comparable. Furthermore, the catalytic activity of sulfamic acid was maintained, even after three cycles.
para-Toluene sulfonic acid ( $p$-TSA) catalyses both the esterification of $\beta$-keto acids and the transesterification of $\beta$-keto esters in comparable yields (Table 67). ${ }^{151}$ Good yields were achieved with aliphatic (entries 1-7 and 10-12) and aromatic (entries 8 and 9) alcohols, but bulkier substrates such as tertbutanol (entry 5 and 11) furnished lower yields. Substituting methyl acetoacetate (entries 1-8) with ethyl acetoacetate (entries 9-12) afforded near identical yields.

$N$-Bromosuccinimide (NBS) is a standard brominating agent which may also be exploited for the selective transesterification of $\beta$-keto esters (Table 68). ${ }^{152}$ Structurally diverse $\beta$-keto esters including alkyl (entries 1-10, 16), cyclic (entries 11-15) and aromatic (entries 17-22) esters were readily transformed. The substrate scope also encompassed thiols (entry 23) and amines (entry 24). The hydroxyl group of 2-mercaptoethanol reacted preferentially (entry 25). In the case of amino alcohols, reaction at the more nucleophilic amine afforded the corresponding amide in $79 \%$ yield (entry 26). Diol substrates were converted to the diester (entry 27). The authors also investigated related reagents and found that $N$-chlorosuccinimide (NCS) was an equally effective catalyst. By contrast, $N$-chloronicotinamide (NCN) returned incomplete conversions and poor yields. 
Table 61 Amberlyst-15-catalysed transesterification ${ }^{138}$

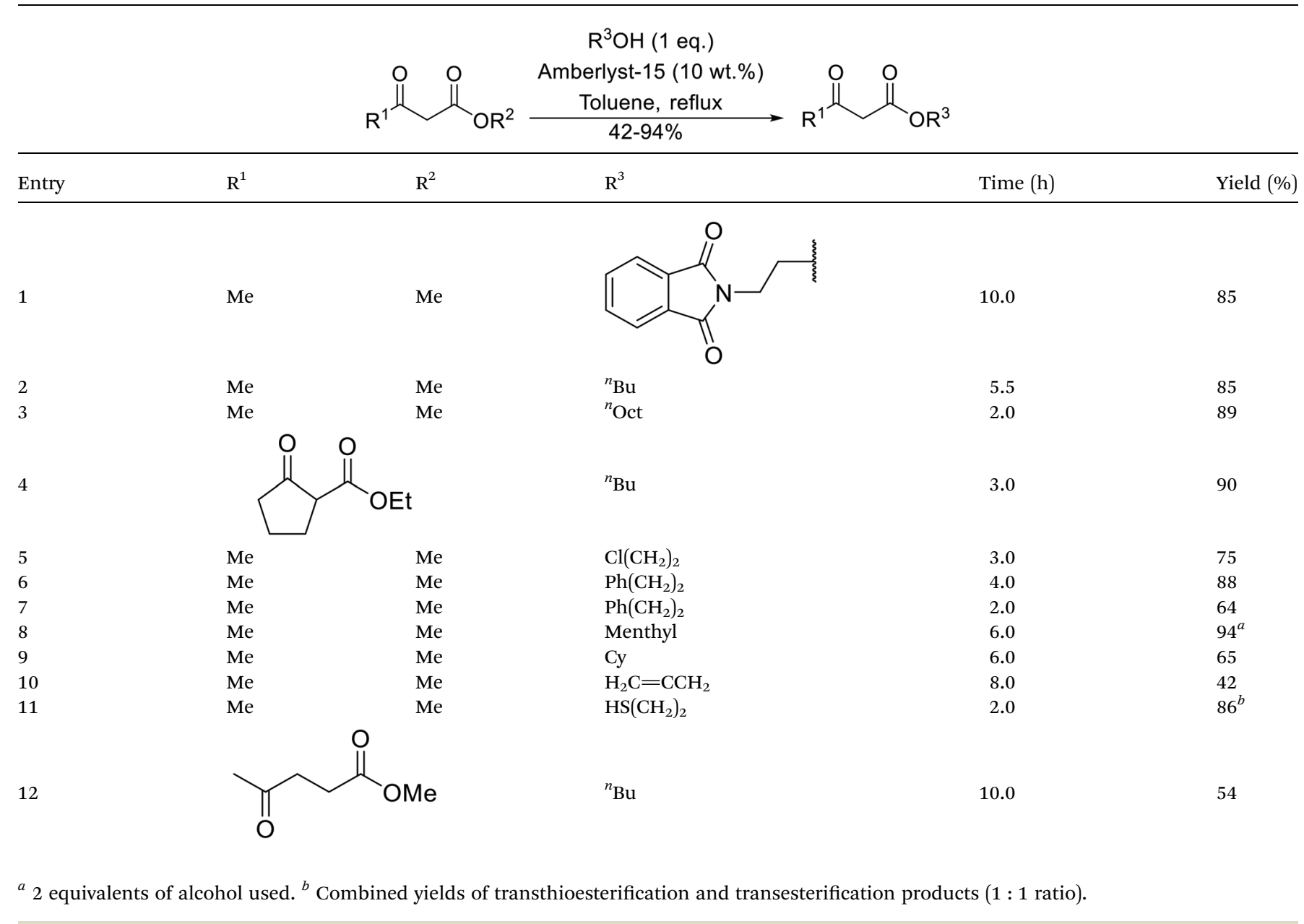

Table 62 Reduction/transesterification of $\beta$-keto esters using sodium borohydride ${ }^{139}$

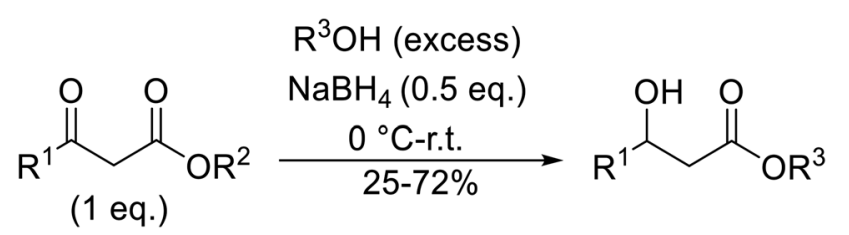

\begin{tabular}{|c|c|c|c|c|c|}
\hline 1 & $\mathrm{Me}$ & $\mathrm{Me}$ & Et & 12 & $65^{a}$ \\
\hline 2 & $\mathrm{Me}$ & $\mathrm{Me}$ & ${ }^{n} \operatorname{Pr}$ & 12 & $62^{a}$ \\
\hline 4 & $\mathrm{Me}$ & $\mathrm{Me}$ & ${ }^{\mathrm{i}} \operatorname{Pr}$ & 12 & $45^{a}$ \\
\hline 5 & $\mathrm{Me}$ & Et & $\mathrm{Me}$ & 12 & 72 \\
\hline 6 & $\mathrm{Me}$ & $\mathrm{Et}$ & ${ }^{n} \operatorname{Pr}$ & 12 & 65 \\
\hline 9 & $\mathrm{Me}$ & ${ }^{n} \mathrm{Bu}$ & Et & 12 & $62^{a}$ \\
\hline 10 & $\mathrm{Me}$ & ${ }^{n} \mathrm{Bu}$ & ${ }^{n} \mathrm{Pr}$ & 12 & $61^{a}$ \\
\hline 11 & $\mathrm{Ph}$ & Et & $\mathrm{Me}$ & 18 & $64^{a}$ \\
\hline 12 & $\mathrm{Ph}$ & Et & ${ }^{n} \mathrm{Pr}$ & 18 & $62^{a}$ \\
\hline 13 & $\mathrm{Ph}$ & $\mathrm{Et}$ & ${ }^{n} \mathrm{Bu}$ & 18 & $60^{a}$ \\
\hline 14 & $\mathrm{Ph}$ & Et & $\mathrm{H}_{2} \mathrm{C}=\mathrm{CHCH}_{2}$ & 18 & 72 \\
\hline
\end{tabular}

${ }^{a}$ An increase of $2-21 \%$ in yield was observed when a large excess of alcohol and longer reaction time was used. 
Table 63 Triphenylphosphine-mediated transesterification ${ }^{146}$

\begin{tabular}{|c|c|c|c|c|c|}
\hline \multirow[b]{2}{*}{ Entry } & \multirow[b]{2}{*}{$\mathrm{R}^{1}$} & \multirow{2}{*}{\multicolumn{2}{|c|}{$\begin{array}{c}\mathrm{R}^{3} \mathrm{OH} \text { (1 eq.) } \\
\begin{array}{c}\text { Triphenylphosphine }(10 \mathrm{~mol} \%) \\
\text { Toluene, reflux }\end{array} \\
73-90 \% \\
\mathrm{R}^{3}\end{array}$}} & \multirow[b]{2}{*}{ Time (h) } & \multirow[b]{2}{*}{ Yield (\%) } \\
\hline & & & & & \\
\hline 1 & $\mathrm{Me}$ & $\mathrm{Me}$ & $\mathrm{CH} \equiv \mathrm{CCH}_{2}$ & 6.0 & 90 \\
\hline 2 & $\mathrm{Me}$ & $\mathrm{Me}$ & ${ }^{n} \mathrm{Bu}$ & 6.5 & 87 \\
\hline 3 & $\mathrm{Me}$ & $\mathrm{Me}$ & ${ }^{n}$ Hep & 7.0 & 79 \\
\hline 4 & $\mathrm{Me}$ & $\mathrm{Me}$ & $\mathrm{H}_{2} \mathrm{C}=\mathrm{CH}\left(\mathrm{CH}_{2}\right)_{8}$ & 6.5 & 84 \\
\hline 5 & $\mathrm{Me}$ & $\mathrm{Me}$ & Menthyl & 6.5 & 90 \\
\hline 6 & $\mathrm{Me}$ & Et & $\mathrm{H}_{2} \mathrm{C}=\mathrm{CHCH}_{2}$ & 8.0 & 78 \\
\hline 7 & $\mathrm{Me}$ & Et & $\mathrm{Cl}\left(\mathrm{CH}_{2}\right)_{2}$ & 7.0 & 84 \\
\hline 8 & $\mathrm{Me}$ & $\mathrm{Et}$ & $\mathrm{Ph}\left(\mathrm{CH}_{2}\right)_{2}$ & 6.0 & 90 \\
\hline 9 & $\mathrm{Me}$ & Et & $\left(\mathrm{CH}_{3}\right)_{2} \mathrm{C}=\mathrm{CHCH}_{2}$ & 6.5 & 90 \\
\hline 10 & $\mathrm{Me}$ & Et & $\mathrm{Bn}$ & 6.0 & 78 \\
\hline 11 & & & $\mathrm{Bn}$ & 8.0 & 73 \\
\hline 12 & & & $\mathrm{H}_{2} \mathrm{C}=\mathrm{CHCH}_{2}$ & 7.0 & 84 \\
\hline 13 & $\mathrm{Ph}$ & Et & $\mathrm{H}_{2} \mathrm{C}=\mathrm{CHCH}_{2}$ & 6.0 & 87 \\
\hline 14 & $\mathrm{Ph}$ & Et & ${ }^{n} \mathrm{Hep}$ & 6.5 & 88 \\
\hline 15 & $\mathrm{Ph}$ & Et & $\mathrm{H}_{2} \mathrm{C}=\mathrm{CH}\left(\mathrm{CH}_{2}\right)_{8}$ & 6.0 & 86 \\
\hline
\end{tabular}

Building upon their previous work involving iodine-activated zinc catalysis (Table 32), Chavan et al. subsequently reported how iodine alone behaves as an efficient transesterification catalyst (Table 69). ${ }^{\mathbf{1 5 3}}$ Transesterification of $\beta$-keto esters with benzyl (entry 11), allylic (entry 9) and propargyl (entry 10) alcohols proceeded in moderate to high yields. In most cases, 1.2 equivalents of alcohol proved sufficient. However, in the case of volatile alcohols, such as $n$-propanol (entry 6) and isopropanol (entry 7), two equivalents were required. The diester product was generated when a diol was introduced (entry 3). Phenols failed to react with either methyl acetoacetate or ethyl acetoacetate. By contrast, the zinc/iodine-catalysed transformation of phenols was successful (Scheme 7).

A mixture of polyethylene glycol (PEG) ionic liquids and toluene may display both homogeneous and heterogeneous phases at different temperatures (e.g., bi-phasic conditions at lower temperatures and mono-phasic at higher temperatures). Ren and Cai investigated the transesterification of ethyl and methyl esters using a catalytic amount of iodine in PEG ionic liquid (Table 70). ${ }^{\mathbf{1 5 4}}$ The authors found that heating to reflux was essential as the reaction was sluggish and low yielding at room temperature. $\beta$-Ketoesters were produced in good yields from aliphatic (entries 1-7 and 9-11) and aromatic (entries 8 and 12) alcohols. The reaction of tert-butanol afforded the corresponding ester in only moderate yields (entries 5 and 10). The catalyst could be reused four times with satisfactory results.
Bandgar et al. compared sodium periodate, potassium periodate and anhydrous calcium chloride as potential transesterification catalysts (Table 71). ${ }^{155}$ The transformation of bulky tertiary alcohols (entries 4, 5 and 10) and unsaturated alcohols (entries 2, 4, 7 and 12), which are often problematic substrates in acid-catalysed reactions, was successfully realised by these catalysts albeit in modest yields. Of the three catalysts studied, potassium periodate generally afforded the highest yields and shortest reaction times. This methodology is highly specific for $\beta$-keto esters and other esters (e.g., $\alpha$-keto esters) remained unreacted. Amine, phenol or thiol nucleophiles proved similarly unreactive.

In related work, Bandgar examined the catalytic activity of sodium perborate ${ }^{156}$ and lithium perchlorate ${ }^{157}$ (Table 72). Both catalysts were selective for $\beta$-keto esters (entries 1-12). The yields were comparable for both catalysts across all substrates tested (entries 1-12). However, sodium perborate is cheaper and less acidic than lithium perchlorate. A notable drop in yield was recorded for the bulky alcohol triphenylmethanol (entry 7).

The effectiveness of caesium fluoride as a transesterification catalyst was investigated by Inahashi and colleagues. ${ }^{158}$ Caesium chloride, caesium bromide and caesium iodide were examined under identical conditions, and caesium fluoride was found to be the superior catalyst. The optimal loading of 
Table 64 [NMP $^{+} \mathrm{HSO}_{4}{ }^{-}$catalysis $^{148}$

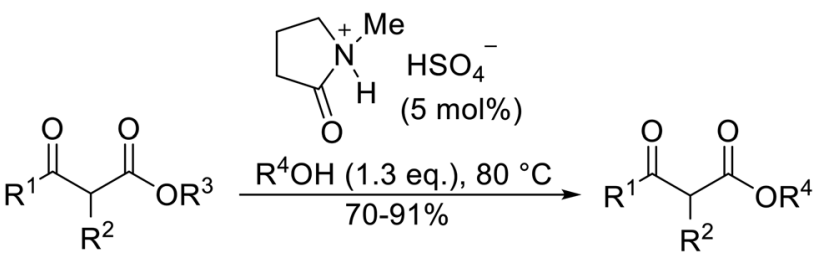

\begin{tabular}{|c|c|c|c|c|c|c|c|}
\hline Entry & $\mathrm{R}^{1}$ & $\mathrm{R}^{2}$ & $\mathrm{R}^{3}$ & $\mathrm{R}^{4}$ & Time (h) & Conversion $^{a}(\%)$ & Yield $^{a}(\%)$ \\
\hline 1 & $\mathrm{Me}$ & $\mathrm{H}$ & $\mathrm{Me}$ & ${ }^{n} \mathrm{Bu}$ & 3 & 80 & 79 \\
\hline 2 & $\mathrm{Me}$ & $\mathrm{H}$ & $\mathrm{Me}$ & ${ }^{n} \mathrm{Hex}$ & 3 & 93 & 90 \\
\hline 4 & $\mathrm{Me}$ & $\mathrm{H}$ & $\mathrm{Me}$ & ${ }^{n}$ Oct & 3 & 92 & 91 \\
\hline 5 & $\mathrm{Me}$ & $\mathrm{H}$ & $\mathrm{Me}$ & ${ }^{\mathrm{i}} \mathrm{Bu}$ & 3 & 88 & 84 \\
\hline 6 & $\mathrm{Me}$ & $\mathrm{H}$ & $\mathrm{Me}$ & ${ }^{\mathrm{i}} \mathrm{Pr}$ & 3.5 & 87 & 74 \\
\hline 9 & $\mathrm{Me}$ & $\mathrm{H}$ & $\mathrm{Me}$ & $\mathrm{PhCH}=\mathrm{CHCH}_{2}$ & 3 & 91 & 87 \\
\hline 10 & $\mathrm{Me}$ & $\mathrm{H}$ & $\mathrm{Me}$ & $\mathrm{CH}_{3} \mathrm{CH}=\mathrm{CHCH}_{2}$ & 3 & 95 & 90 \\
\hline 11 & $\mathrm{Me}$ & $\mathrm{H}$ & $\mathrm{Me}$ & $\mathrm{H}_{2} \mathrm{C}=\mathrm{CHCH}_{2}$ & 3 & 92 & 86 \\
\hline 12 & $\mathrm{Me}$ & $\mathrm{H}$ & Et & ${ }^{n} \mathrm{Bu}$ & 3 & 83 & 78 \\
\hline 13 & $\mathrm{Me}$ & $\mathrm{H}$ & Et & ${ }^{n} \mathrm{Hex}$ & 3 & 94 & 85 \\
\hline 14 & $\mathrm{Me}$ & $\mathrm{H}$ & Et & ${ }^{n}$ Oct & 3 & 93 & 84 \\
\hline 18 & & & & ${ }^{n} \mathrm{Bu}$ & 3.5 & 90 & 84 \\
\hline 19 & $\mathrm{Ph}$ & $\mathrm{H}$ & $\mathrm{Et}$ & ${ }^{n}$ Oct & 3.5 & 88 & 83 \\
\hline
\end{tabular}

Table $65 \quad\left[C_{3} \mathrm{MIm}\right] \mathrm{Cl} /$ sulfamic acid-catalysed transesterification of methyl acetoacetate ${ }^{149}$

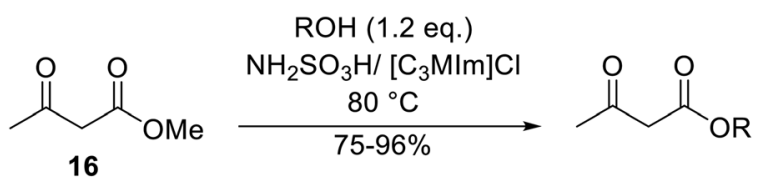

16

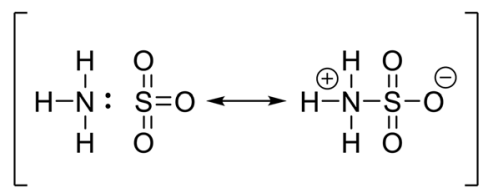

\begin{tabular}{llll}
\hline Entry & $\mathrm{R}$ & Time (h) & Yield $^{a}(\%)$ \\
\hline 1 & ${ }^{n} \mathrm{Bu}$ & 3.0 & $96\left(86^{b}\right)$ \\
2 & ${ }^{s e c} \mathrm{Bu}$ & 3.0 & 95 \\
3 & ${ }^{t} \mathrm{Bu}$ & 4.5 & 75 \\
4 & ${ }^{n} \mathrm{Hex}$ & 3.0 & 95 \\
5 & $\mathrm{Cy}$ & 3.0 & 94 \\
6 & $\mathrm{H}_{2} \mathrm{C}=\mathrm{CHCH}_{2}$ & 9.0 & 93 \\
7 & $\mathrm{HC} \equiv \mathrm{CCH}_{2}$ & 4.0 & 93 \\
8 & $\mathrm{Bn}$ & & \\
9 & & & 4.0
\end{tabular}

${ }^{a}$ GC yield. ${ }^{b}$ Yield after 5 cycles. 
Table 66 Sulfamic acid-catalysed transesterification of methyl acetoacetate ${ }^{150}$

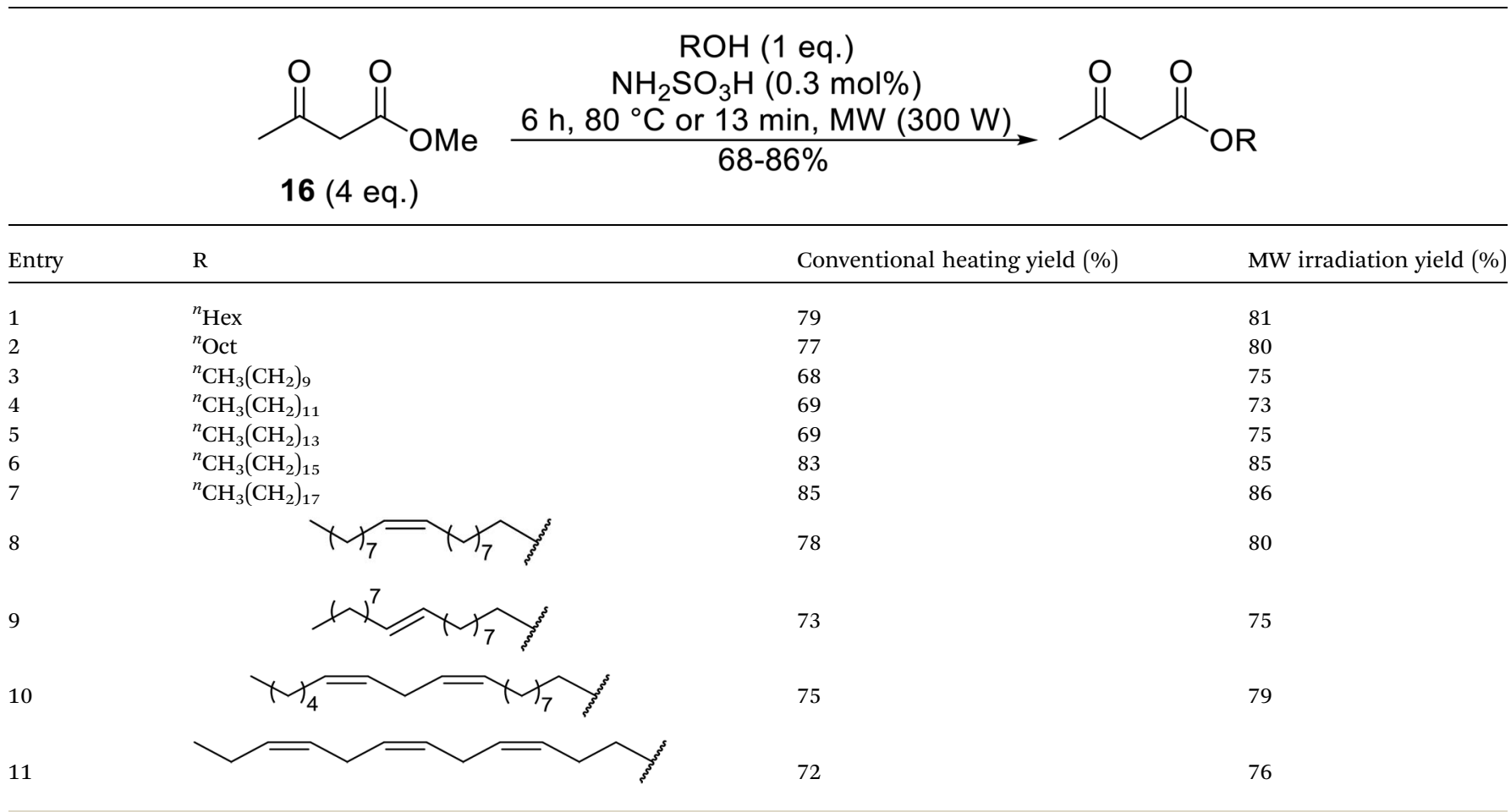

Table 67 Catalysis with para-toluene sulfonic acid ${ }^{151}$

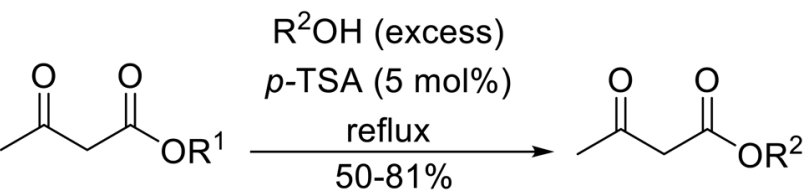

\begin{tabular}{|c|c|c|c|}
\hline Entry & $\mathrm{R}^{1}$ & $\mathrm{R}^{2}$ & Yield (\%) \\
\hline 1 & $\mathrm{Me}$ & ${ }^{n} \operatorname{Pr}$ & 71 \\
\hline 2 & $\mathrm{Me}$ & ${ }^{\mathrm{i}} \mathrm{Pr}$ & 65 \\
\hline 4 & $\mathrm{Me}$ & ${ }^{\sec } \mathrm{Bu}$ & 73 \\
\hline 5 & $\mathrm{Me}$ & ${ }^{t} \mathrm{Bu}$ & 50 \\
\hline 6 & $\mathrm{Me}$ & ${ }^{n} \mathrm{Bu}$ & 78 \\
\hline 9 & Et & $\mathrm{Bn}$ & 70 \\
\hline 10 & Et & ${ }^{n} \mathrm{Bu}$ & 80 \\
\hline 11 & Et & ${ }^{t} \mathrm{Bu}$ & 51 \\
\hline 12 & Et & $\mathrm{Cy}$ & 68 \\
\hline
\end{tabular}

caesium fluoride was $10 \mathrm{~mol} \%$ (Table 73), but quantitative transesterification was observed with $2 \mathrm{~mol} \%$ albeit at the cost of longer reaction times (entry 2). Acyclic (entries 1, 3-6 and 11), cyclic (entries 7 and 8) and aromatic esters (entries 9 and 10) furnished the desired products in excellent yields. The non- enolisable $\beta$-keto ester methyl 2,2-dimethyl-3-oxobutanoate was readily converted in $93 \%$ yield on increasing the catalyst loading to $10 \mathrm{~mol} \%$ (entry 26). Allylic (entries 12-14), propargylic (entry 15), acid-sensitive (entries 14, 16 and 17) and basesensitive (entry 18) alcohols reacted smoothly in good yields. 
View Article Online

Review

RSC Advances

Table $68 \quad N$-Bromosuccinimide catalysis ${ }^{152}$<smiles>[R]C(=O)CC([R])=O</smiles>

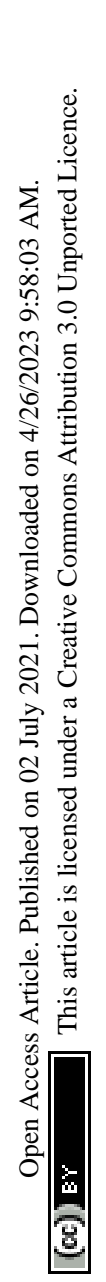

11<smiles>CCOC(=O)C1CCCC1=O</smiles>

12<smiles>CCOC(=O)C1CCCC1=O</smiles>

13<smiles>CCOC(=O)C1CCCC1=O</smiles>

Et

$\begin{array}{ll}\mathrm{R}^{2} & \mathrm{R}^{3} \\ \mathrm{Me} & \mathrm{PrO} \\ \mathrm{Et} & \mathrm{PrO} \\ \mathrm{Pr} & \mathrm{BuO} \\ \mathrm{Bu} & \mathrm{PrO} \\ \mathrm{Et} & \mathrm{CyO} \\ \mathrm{Et} & \mathrm{Menthyl} \\ \mathrm{Et} & { }_{\mathrm{BuO}} \\ \mathrm{Et} & \mathrm{PhCH}=\mathrm{CHCH}_{2} \mathrm{O} \\ \mathrm{Et} & \end{array}$

$\mathrm{BuO}$

3.5

10

Me

14<smiles>CCOC(=O)C1CCCC1=O</smiles>

15<smiles>CCOC(=O)C1CCCC1=O</smiles>

16

Me

Menthyl

$\mathrm{Ph}$

Et

18

2,3,4-(MeO) $)_{3}-\mathrm{C}_{6} \mathrm{H}_{2}$

19

2,3,4-(MeO $)_{3}-\mathrm{C}_{6} \mathrm{H}_{2}$

Et

20

$\mathrm{Ph}$

Et
Menthyl

$\mathrm{Ph}_{3} \mathrm{CO}$

$\mathrm{BuO}$

$\mathrm{PhCH}=\mathrm{CHCH}_{2} \mathrm{O}$

$\mathrm{PhCH}=\mathrm{CHCH}_{2} \mathrm{O}$<smiles>CC(C)(C)OC/C=C/c1ccc2c(c1)OCO2</smiles>

Menthyl
4

8

4

72

4

85

4

83

87

52

6

50

84

81

7

81

4

77

(c) 2021 The Author(s). Published by the Royal Society of Chemistry

RSC AdV., 2021, 11, 22859-22920 | 22911 


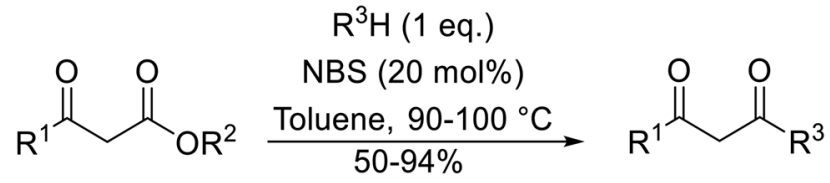

\begin{tabular}{|c|c|c|c|c|c|}
\hline Entry & $\mathrm{R}^{1}$ & $\mathrm{R}^{2}$ & $\mathrm{R}^{3}$ & Time (h) & Yield (\%) \\
\hline 21 & $\mathrm{Ph}$ & Et & & 4 & 77 \\
\hline 22 & $\mathrm{EtC}$ & Et & $\mathrm{PhCH}=\mathrm{CHCH}_{2} \mathrm{O}$ & 2 & 77 \\
\hline 23 & Me & Et & 4-Cl- $\mathrm{C}_{6} \mathrm{H}_{4} \mathrm{~S}$ & 6 & 75 \\
\hline 24 & Me & Et & 3-Cl- $\mathrm{C}_{6} \mathrm{H}_{4} \mathrm{NH}$ & 4 & 80 \\
\hline 25 & Me & Et & $\mathrm{HS}\left(\mathrm{CH}_{2}\right)_{2} \mathrm{O}$ & 4 & 89 \\
\hline 26 & Me & Et & $\mathrm{H}_{2} \mathrm{~N}$ & 4 & 79 \\
\hline 27 & Me & Et & $\mathrm{HO}\left(\mathrm{CH}_{2}\right)_{2} \mathrm{O}$ & 4 & 80 \\
\hline
\end{tabular}

Table 69 lodine-mediated catalysis ${ }^{153}$

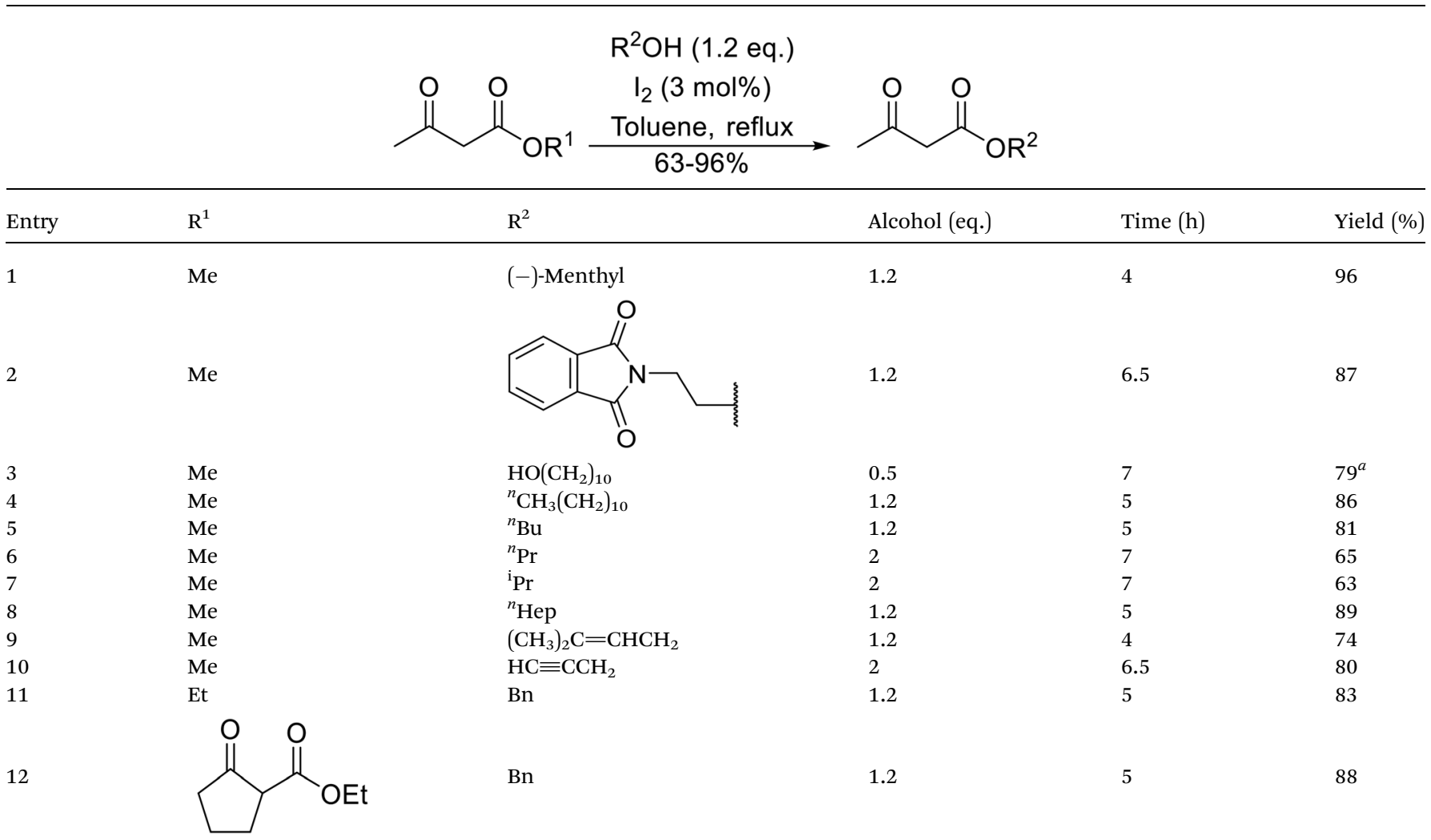




Entry

Table 70 Transesterification of $\beta$-keto esters using iodine in PEG ionic liquid ${ }^{154}$

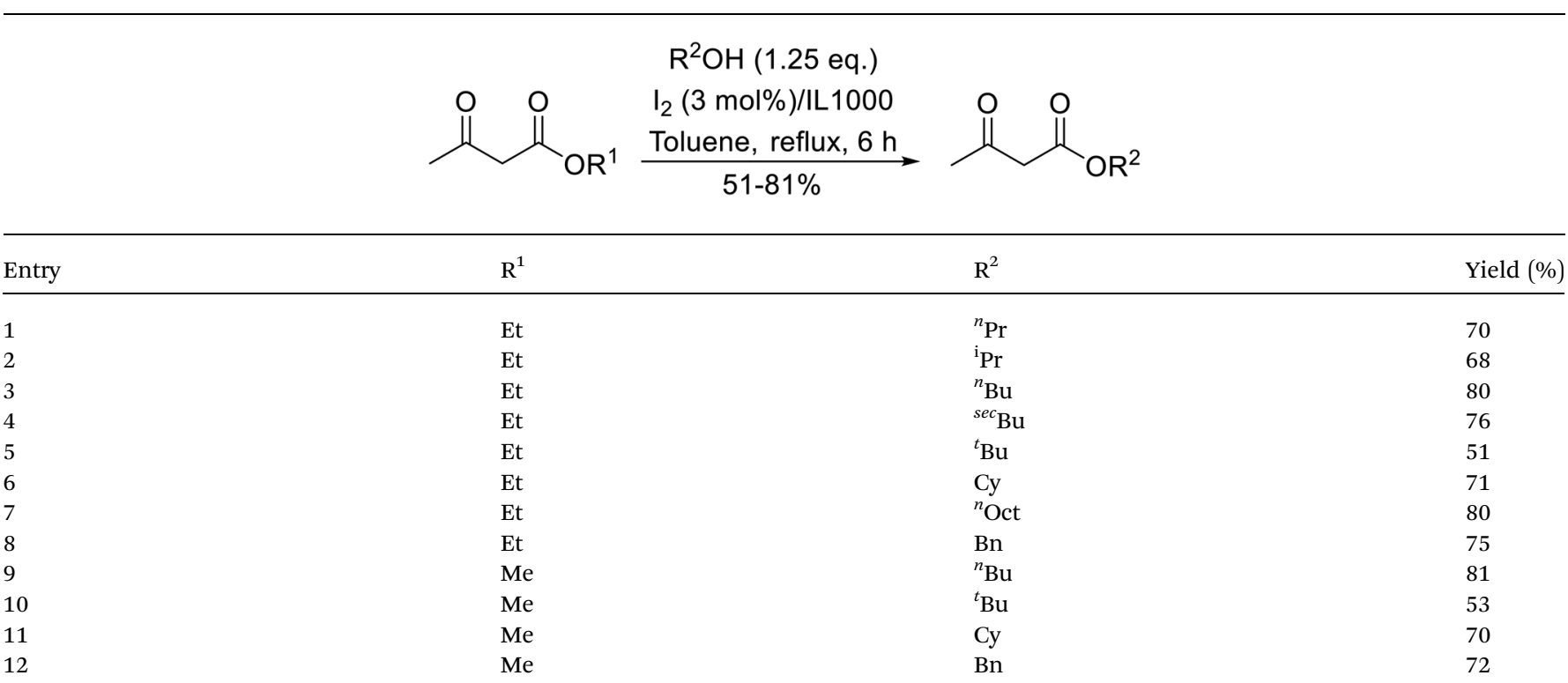

Alcohols carrying tertiary amines were also transesterified in good yields (entries 20 and 21). Additionally, sterically hindered secondary alcohols, such as borneol (entry 22) and menthol (entry 23), as well as less reactive tertiary alcohols (entries 24 and 25), afforded the corresponding $\beta$-keto esters in moderate to good yields. The catalyst could be reused at least ten times without any appreciable decrease in activity.

\section{Conclusion}

The ability to selectively transesterify $\beta$-keto esters remains an important transformation in organic chemistry. As the market for alternative fuels, such as biodiesel, grows, the demand for robust and reliable transesterification methodologies will increase accordingly. Chemists are continually searching for higher yielding, milder and more environmentally benign conditions with broad substrate scope. In addition to traditional approaches based around metal catalysts, a variety of 
Table 71 Comparison of sodium periodate, potassium periodate and anhydrous calcium chloride catalysis ${ }^{155}$

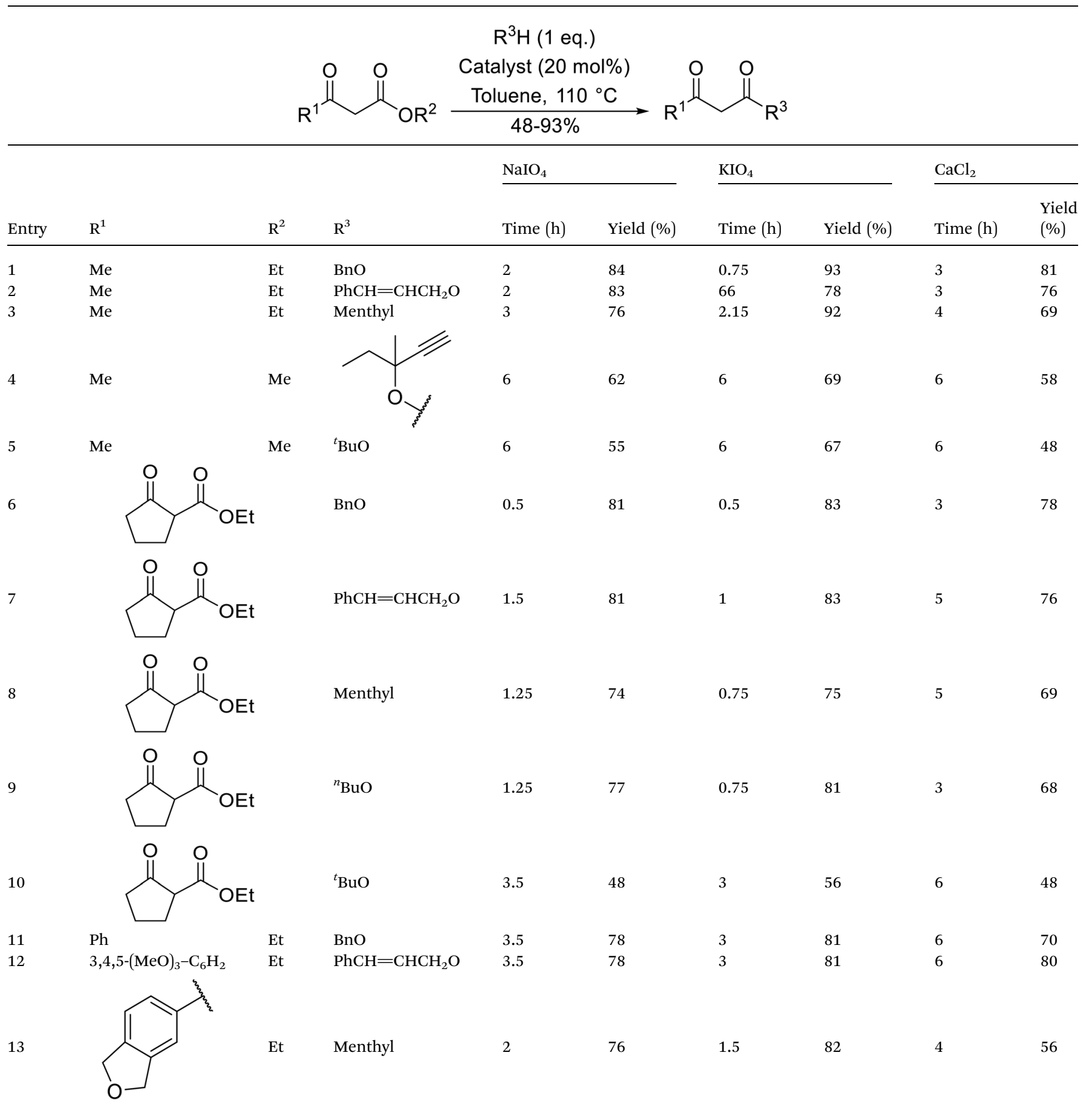


Table 72 Sodium perborate or lithium perchlorate catalysis ${ }^{156,157}$

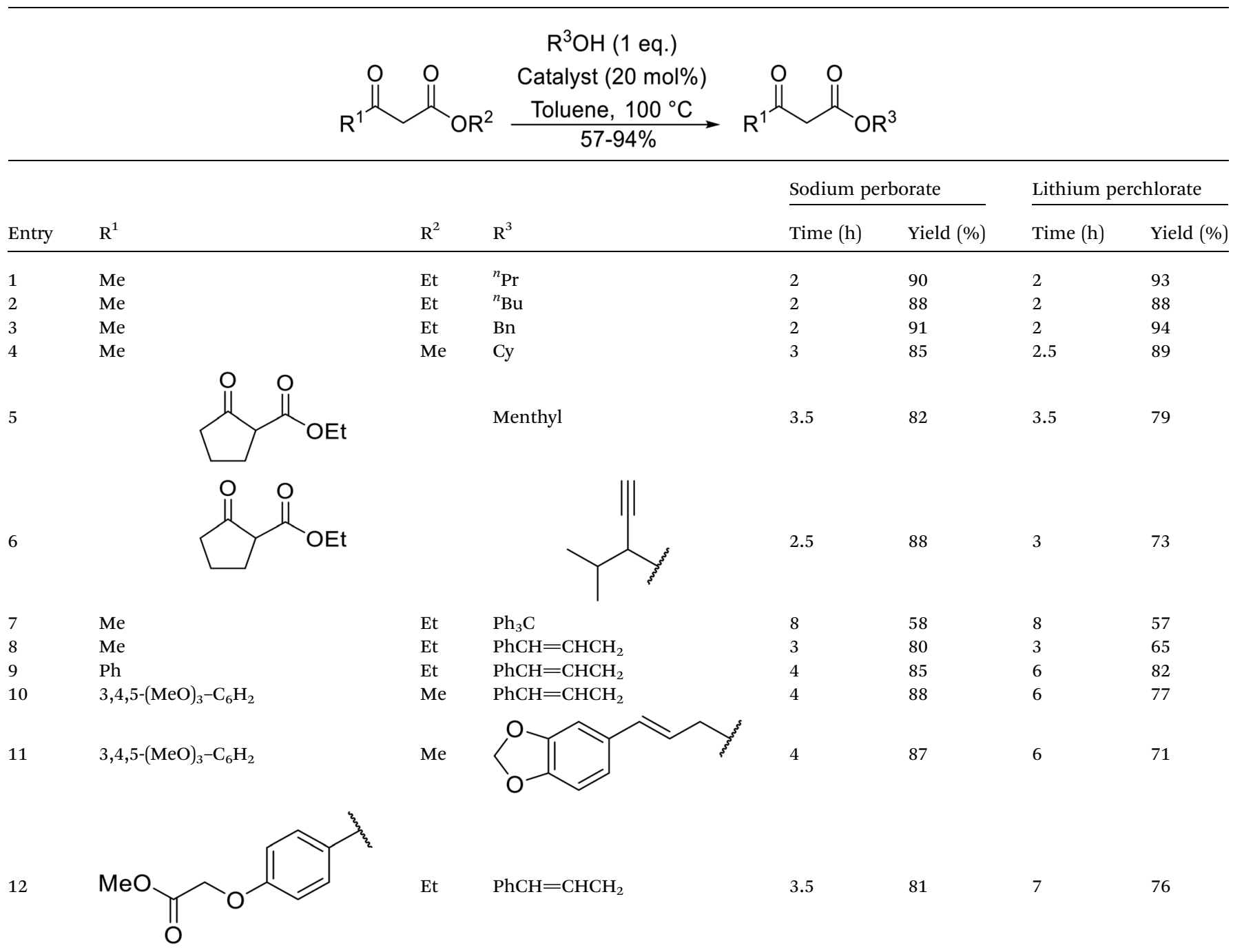

Table 73 Transesterification using caesium fluoride $\mathrm{e}^{158}$

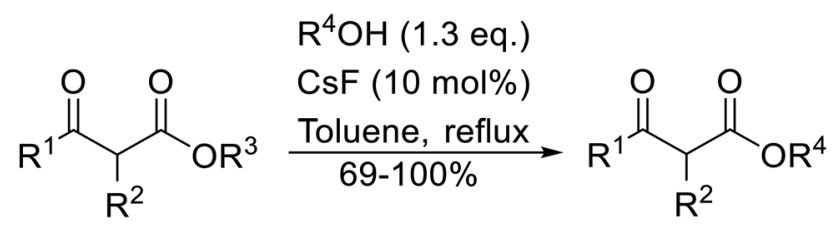

\begin{tabular}{llllll}
\hline Entry & $\mathrm{R}^{1}$ & $\mathrm{R}^{2}$ & $\mathrm{R}^{3}$ & $\mathrm{R}^{4}$ & Time (h) \\
\hline 1 & $\mathrm{Me}$ & $\mathrm{H}$ & $\mathrm{Me}$ & ${ }^{n}$ Oct & 18 \\
2 & $\mathrm{Me}$ & $\mathrm{H}$ & $\mathrm{Me}$ & ${ }^{n}$ Oct & 93 \\
3 & $\mathrm{Me}$ & $\mathrm{H}$ & $\mathrm{Et}$ & ${ }^{n}$ Oct & 93 \\
4 & $\mathrm{H}$ & ${ }^{\mathrm{i}} \mathrm{Pr}$ & ${ }^{n}$ Oct & 22 \\
5 & ${ }^{n} \mathrm{Pr}$ & $\mathrm{H}$ & $\mathrm{Et}$ & ${ }^{n}$ Oct & 48 \\
\end{tabular}


Table 73 (Contd.)

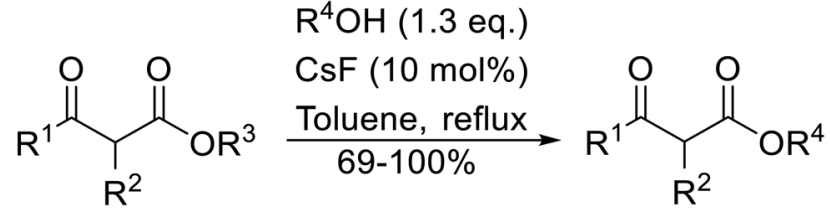

\begin{tabular}{lllllll}
\hline Entry & $\mathrm{R}^{1}$ & $\mathrm{R}^{2}$ & $\mathrm{R}^{3}$ & $\mathrm{R}^{4}$ & Time (h) \\
\hline 6 & $\mathrm{Me}$ & $\mathrm{Me}$ & $\mathrm{Et}$ & ${ }^{n}$ Oct & 17 & Yield (\%)
\end{tabular}

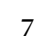<smiles>COC(=O)C1CCCC1=O</smiles>

${ }^{n}$ Oct<smiles>CCOC(=O)C1CCCCC1=O</smiles>

${ }^{n}$ Oct

9

${ }^{n}$ Oct

$\mathrm{Cl}\left(\mathrm{CH}_{2}\right)_{6}$

${ }^{t} \mathrm{BuMe}_{2} \mathrm{SiO}\left(\mathrm{CH}_{2}\right)_{6}-$

$\begin{array}{ll}\mathrm{H} & \mathrm{Et} \\ \mathrm{H} & \mathrm{Et}\end{array}$

21

${ }^{n} \operatorname{Pr}$

$\mathrm{H}$
${ }^{n}$ Oct

${ }^{n}$ Oct<smiles>CCCC=CCCC</smiles>

13.5

8.5

10.5

18

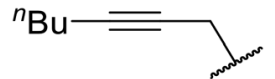<smiles>CC(C)CC1COc2ccccc2O1</smiles>

27

85<smiles>CC(C)CC(C)(C)C1CO1</smiles>

18

82

$\mathrm{Me}_{2} \mathrm{~N}\left(\mathrm{CH}_{2}\right)_{2}$

28

8

30

87<smiles>CC(C)CCN1CCOCC1</smiles>

Borneol

Menthol

1-Adamantol<smiles>CCCCC(C)(C)CC</smiles>

6.5

6

82

81

96

80

93

79

32

80

25

43

38

40

73

${ }^{n}$ Oct

23

93

${ }^{a} 2$ mol\% CsF was used.<smiles>COC(=O)C(C)(C)C(C)=O</smiles> 
novel methodologies incorporating enzymes, clays or even catalyst-free conditions have been described in this review. Chemists can look forward to even more innovation in this field in the years ahead.

\section{Conflicts of interest}

There are no conflicts to declare.

\section{Acknowledgements}

$\mathrm{MCH}$ is grateful for funding by way of a Government of Ireland Postgraduate Research Scholarship (GOIPG/2018/496) provided by the Irish Research Council.

\section{References}

1 S. Benetti, R. Romagnoli, C. De Risi, G. Spalluto and V. Zanirato, Chem. Rev., 1995, 95, 1065-1114.

2 T. Mandai, A. Kuroda, H. Okumoto, K. Nakanishi, K. Mikuni, K.-J. Hara and K.-Z. Hara, Tetrahedron Lett., 2000, 41, 239-242.

3 Y. Usuki, H. Ogawa, K.-I. Yoshida, T. Inaoka and H. Iio, Asian J. Org. Chem., 2015, 4, 737-740.

4 T. J. Brocksom, F. Coelho, J.-P. Deprés, A. E. Greene, M. E. Freire de Lima, O. Hamelin, B. Hartmann, A. M. Kanazawa and Y. Wang, J. Am. Chem. Soc., 2002, 124, 15313-15325.

5 B. B. Snider and B. O. Buckman, J. Org. Chem., 1992, 57, 4883-4888.

6 R. M. Pollack, in Transition States of Biochemical Processes, ed. R. D. Gandour and R. L. Schowen, Springer US, Boston, MA, 1978, pp. 467-492.

7 L. C. Meher, D. Vidya Sagar and S. N. Naik, Renewable Sustainable Energy Rev., 2006, 10, 248-268.

8 D. Y. C. Leung, X. Wu and M. K. H. Leung, Appl. Energy, 2010, 87, 1083-1095.

9 J. Makarević and M. Žinić, Croat. Chem. Acta, 1998, 71, 817825.

10 D. S. Campbell and C. W. Lawrie, J. Chem. Soc. D, 1971, 355356.

11 J. Otera, Chem. Rev., 1993, 93, 1449-1470.

12 H. E. Hoydonckx, D. E. De Vos, S. A. Chavan and P. A. Jacobs, Top. Catal., 2004, 27, 83-96.

13 D. G. Hall, Chem. Soc. Rev., 2019, 48, 3475-3496.

14 R. Pal, ARKIVOC, 2018, 346-371.

15 G. C. M. Kondaiah, L. A. Reddy, K. S. Babu, V. M. Gurav, K. G. Huge, R. Bandichhor, P. P. Reddy, A. Bhattacharya and R. V. Anand, Tetrahedron Lett., 2008, 49, 106-109.

16 R. Tale, S. Shinde, V. Gopula and D. Wankhede, J. Chem. Pharm. Res., 2016, 8, 169-175.

17 M. F. Carroll, J. Chem. Soc., 1940, 704-706.

18 M. F. Carroll, J. Chem. Soc., 1941, 507-511.

19 W. Kimel and A. C. Cope, J. Am. Chem. Soc., 1943, 65, 19921998.

20 F. E. Ziegler, Chem. Rev., 1988, 88, 1423-1452.
21 R. H. Tale, A. D. Sagar, H. D. Santan and R. N. Adude, Synlett, 2006, 415-418.

22 J. Yang, C. Ji, Y. Zhao, Y. Li, S. Jiang, Z. Zhang, Y. Ji and W. Liu, Synth. Commun., 2010, 40, 957-963.

23 B. R. Madje, P. T. Patil, S. S. Shindalkar, S. B. Benjamin, M. S. Shingare and M. K. Dongare, Catal. Commun., 2004, 5, 353-357.

24 D. F. Taber, J. C. Amedio and Y. K. Patel, J. Org. Chem., 1985, 50, 3618-3619.

25 J. C. Gilbert and T. A. Kelly, J. Org. Chem., 1988, 53, 449-450.

26 J. Christoffers and N. Önal, Eur. J. Org. Chem., 2000, 16331635.

27 S. Shinoda and A. Osuka, Tetrahedron Lett., 1996, 37, 49454948.

28 O. Mhasni and F. Rezgui, Tetrahedron, 2011, 67, 6322-6326.

29 O. Mhasni and F. Rezgui, Tetrahedron Lett., 2010, 51, 586587.

30 O. Mhasni, I. Erray and F. Rezgui, Synth. Commun., 2014, 44, 3320-3327.

31 S. Palaniappan and R. Chandra Shekhar, Polym. Adv. Technol., 2004, 15, 140-143.

32 K.-I. Shimizu, H. Suzuki, E. Hayashi, T. Kodama, Y. Tsuchiya, H. Hagiwara and Y. Kitayama, Chem. Commun., 2002, 1068-1069.

33 K.-I. Shimizu, E. Hayashi, T. Inokuchi, T. Kodama, H. Hagiwara and Y. Kitayama, Tetrahedron Lett., 2002, 43, 9073-9075.

34 H. Hagiwara, A. Koseki, K. Isobe, K.-I. Shimizu, T. Hoshi and T. Suzuki, Synlett, 2004, 2188-2190.

35 R. Ribeiro, R. de Souza, M. Vasconcellos, B. Oliveira, L. Ferreira and L. Aguiar, Synthesis, 2007, 61-64.

36 N. Blažzević, D. Kolbah, B. Belin, V. Šunjić and F. Kajfež, Synthesis, 1979, 161-176.

37 C. H. Wong and G. M. Whitesides, in Tetrahedron Organic Chemistry Series, Elsevier, Oxford, 1994, vol. 12, pp. 41-130.

38 A. M. Bezborodov and N. A. Zagustina, Appl. Biochem. Microbiol., 2014, 50, 313-337.

39 A. Córdova and K. D. Janda, J. Org. Chem., 2001, 66, 19061909.

40 G. D. Yadav and P. S. Lathi, J. Mol. Catal. B: Enzym., 2005, 32, 107-113.

41 G. D. Yadav and P. S. Lathi, J. Mol. Catal. A: Chem., 2004, 223, 51-56.

42 C. Wiśniewska, D. Koszelewski, M. Zysk, S. Kłossowski, A. Żądło, A. Brodzka and R. Ostaszewski, Eur. J. Org. Chem., 2015, 5432-5437.

43 B. Reddy and V. Reddy, Synth. Commun., 1999, 29, 12351239.

44 Z.-h. Chen, T. Iizuka and K. Tanabe, Chem. Lett., 1984, 13, 1085-1088.

45 K. Srilatha, T. Issariyakul, N. Lingaiah, P. S. Sai Prasad, J. Kozinski and A. K. Dalai, Energy Fuels, 2010, 24, 47484755 .

46 S. Okazaki and A. Kurosaki, Catal. Today, 1990, 8, 113-122. 47 T. Ushikubo, Catal. Today, 2000, 57, 331-338. 
48 L. C. Kao, W. C. Kan, R. M. Martin-Aranda, M. O. GuerreroPerez, M. Á. Bañares and S. Y. H. Liou, Catal. Today, 2020, 356, 80-87.

49 M. I. de Sairre, É. S. Bronze-Uhle and P. M. Donate, Tetrahedron Lett., 2005, 46, 2705-2708.

50 M. Lakshmi Kantam and B. Bharathi, Catal. Lett., 1998, 55, 235-237.

51 B. M. Choudary, M. Lakshmi Kantam, V. Neeraja, T. Bandyopadhyay and P. Narsi Reddy, J. Mol. Catal. A: Chem., 1999, 140, 25-29.

52 M. Lakshmi Kantam, V. Neeraja, B. Bharathi and C. Venkat Reddy, Catal. Lett., 1999, 62, 67-69.

53 M. Li, J. Yang and Y. Gu, Adv. Synth. Catal., 2011, 353, 15511564.

54 P. Krasik, Tetrahedron Lett., 1998, 39, 4223-4226.

55 W. G. Devine, N. E. Leadbeater and L. A. Jacob, Future Med. Chem., 2010, 2, 225-230.

56 G. Shapiro and M. Marzi, J. Org. Chem., 1997, 62, 70967097.

57 H. Niu, J. Yao, Y. Wang and G. Wang, Catal. Commun., 2007, 8, 355-358.

58 T. Raja Mani, Y. Hemanth Sriram, K. Bhaskar, A. K. Kumar and K. R. Kudle, Chem. Methodol., 2018, 2, 83-92.

59 P. Vijayshekar, Y. Hemanth Sriram, M. Raju, R. Ajay Kumar and K. R. Kudle, Asian J. Green Chem., 2018, 2, 132-143.

60 H. Yue, H. Yu, S. Liu and C. Xu, RSC Adv., 2016, 6, 1904119051.

61 D. Damodara, R. Arundhathi and P. R. Likhar, Adv. Synth. Catal., 2014, 356, 189-198.

62 R. Das and D. Chakraborty, Appl. Organomet. Chem., 2012, 26, 140-144.

63 B. P. Bandgar, V. S. Sadavarte and L. S. Uppalla, Synth. Commun., 2001, 31, 2063-2066.

64 R. Hudson, Synlett, 2013, 24, 1309-1310.

65 M. Gohain, V. Kumar, J. H. van Tonder, H. C. Swart, O. M. Ntwaeaborwa and B. C. B. Bezuidenhoudt, RSC Adv., 2015, 5, 18972-18976.

66 C. F. Petten, H. A. Kalviri and F. M. Kerton, Sustainable Chem. Processes, 2015, 3, 16.

67 A. Navrotsky, J. Mater. Chem., 2005, 15, 1883-1890.

68 P. Kumar and R. Pandey, Synlett, 2000, 251-253.

69 G. Krishnaiah, B. Sandeep, D. Kondhare, K. C. Rajanna, J. Narendar Reddy, Y. Rajeshwar Rao and P. K. Zhubaidha, Tetrahedron Lett., 2013, 54, 703-706.

70 G. Krishnaiah, K. C. Rajanna, K. R. Reddy, M. S. Kumar, P. Srinivas and Y. R. Rao, Res. Chem. Intermed., 2015, 41, 2739-2751.

71 P. Srinivas, K. C. Rajanna, G. Krishnaiah, M. S. Kumar and J. N. Reddy, Synth. React. Inorg., Met.-Org., Nano-Met. Chem., 2014, 44, 1212-1220.

72 J. Balmaseda, E. Reguera, J. Fernández, A. Gordillo and H. Yee-Madeira, J. Phys. Chem. Solids, 2003, 64, 685-693.

73 S. P. Chavan, K. Shivasankar, R. Sivappa and R. Kale, Tetrahedron Lett., 2002, 43, 8583-8586.
74 P. M. Price, J. H. Clark and D. J. Macquarrie, J. Chem. Soc., Dalton Trans., 2000, 101-110.

75 R. K. Sharma and D. Rawat, J. Inorg. Organomet. Polym. Mater., 2011, 21, 619.

76 À. Pericas, A. Shafir and A. Vallribera, Tetrahedron, 2008, 64, 9258-9263.

77 M. M. A. Soliman, A. Karmakar, E. C. B. A. Alegria, A. P. C. Ribeir, G. M. D. M. Rúbio, M. S. Saraiva, M. F. C. G. da Silva and A. J. L. Pombeiro, Catal. Today, 2020, 348, 72-79.

78 B. P. Bandgar, S. S. Pandit and L. S. Uppalla, Org. Prep. Proced. Int., 2003, 35, 219-222.

79 V. Auger and I. Robin, C. R. Hebd. Seances Acad. Sci., 1924, 178, 1546-1548.

80 Y. Hayashi, T. Ohshima, Y. Fujii, Y. Matsushima and K. Mashima, Catal. Sci. Technol., 2011, 1, 230-233.

81 K. Agura, Y. Hayashi, M. Wada, D. Nakatake, K. Mashima and T. Ohshima, Chem.-Asian J., 2016, 11, 1548-1554.

82 Y. Hayashi, S. Santoro, Y. Azuma, F. Himo, T. Ohshima and K. Mashima, J. Am. Chem. Soc., 2013, 135, 6192-6199.

83 T. Iwasaki, Y. Maegawa, Y. Hayashi, T. Ohshima and K. Mashima, J. Org. Chem., 2008, 73, 5147-5150.

84 T. Ohshima, Chem. Pharm. Bull., 2016, 64, 523-539.

85 Y. Maegawa, K. Agura, Y. Hayashi, T. Ohshima and K. Mashima, Synlett, 2012, 137-141.

86 P. Goswami and S. K. Bharadwaj, Catal. Lett., 2008, 124, 100-104.

87 K. Schrödter, G. Bettermann, T. Staffel, F. Wahl, T. Klein and T. Hofmann, in Ullmann's Encyclopedia of Industrial Chemistry, Wiley, Weinheim, Germany, 2008.

88 B. M. Choudary, M. L. Kantam, B. Kavita, C. Venkat Reddy, K. Koteswara Rao and F. Figueras, Tetrahedron Lett., 1998, 39, 3555-3558.

89 B. M. Choudary, M. Lakshmi Kantam, B. Bharathi and C. Venkat Reddy, Synlett, 1998, 1203-1204.

90 B. M. Choudary, M. Lakshmi Kantam, C. Venkat Reddy, S. Aranganathan, P. Lakshmi Santhi and F. Figueras, J. Mol. Catal. A: Chem., 2000, 159, 411-416.

91 R. S. Mohan, N. M. Leonard and L. C. Wieland, Tetrahedron, 2002, 58, 8373-8397.

92 J. M. Bothwell, S. W. Krabbe and R. S. Mohan, Chem. Soc. Rev., 2011, 40, 4649-4707.

93 R. Kuruba, P. Vijayalakshmi and T. Kaimal, Synlett, 2001, 0863-0865.

94 B. V. S. Reddy, R. Srinivas, J. S. Yadav and T. Ramalingam, Synth. Commun., 2001, 31, 1075-1080.

95 G. Sabitha, R. Srinivas, P. Gopal, M. Bhikshapathi and J. Singh Yadav, Helv. Chim. Acta, 2011, 94, 119-121.

96 R. K. Pandey, S. P. Dagade, K. M. Malase, S. B. Songire and P. Kumar, J. Mol. Catal. A: Chem., 2006, 245, 255-259.

97 R. K. Pandey and P. Kumar, Catal. Commun., 2007, 8, 11221125.

98 G. B. Dharma Rao and M. P. Kaushik, Tetrahedron Lett., 2011, 52, 5104-5106. 
99 G. Nagendrappa, Appl. Clay Sci., 2011, 53, 106-138. 100 T. Jin, S. Zhang and T. Li, Green Chem., 2002, 4, 32-34. 101 F. C. da Silva, V. F. Ferreira, R. S. Rianelli and W. C. Perreira, Tetrahedron Lett., 2002, 43, 1165-1168.

102 P. Laszlo, Pure Appl. Chem., 1990, 62, 2027-2030.

103 J. W. Gruner, Z. Kristallogr.-Cryst. Mater., 1932, 83, 75-88.

104 K. Momma and F. Izumi, J. Appl. Crystallogr., 2011, 44, 1272-1276.

105 D. E. Ponde, V. H. Deshpande, V. J. Bulbule and A. Sudalai, J. Org. Chem., 1998, 63, 1058-1063.

106 B. P. Bandgar, L. S. Uppalla and V. S. Sadavarte, Green Chem., 2001, 3, 39-41.

107 R. Ratti, S. Kaur, M. Vaultier and V. Singh, Catal. Commun., 2010, 11, 503-507.

108 G. Sathicq, L. Musante, G. Romanelli, G. Pasquale, J. Autino, H. Thomas and P. Vázquez, Catal. Today, 2008, 133-135, 455-460.

109 G. Sathicq, L. Musantc, G. Romanelli, G. Pasquale, J. C. Autino, H. Thomas and P. Vázquez, Stud. Surf. Sci. Catal., 2006, 162, 227-234.

110 J. Rouquero, D. Avnir, C. W. Fairbridge, D. H. Everett, J. H. Haynes, N. Pernicone, J. D. F. Ramsay, K. S. W. Sing and K. K. Unger, Pure Appl. Chem., 1994, 66, 1739-1758.

111 S. N. Talapaneni, G. P. Mane, A. Mano, C. Anand, D. S. Dhawale, T. Mori and A. Vinu, ChemSusChem, 2012, 5, 700-708.

112 A. Vinu, Adv. Funct. Mater., 2008, 18, 816-827.

113 C. Anand, S. V. Priya, G. Lawrence, G. P. Mane, D. S. Dhawale, K. S. Prasad, V. V. Balasubramanian, M. A. Wahab and A. Vinu, Catal. Today, 2013, 204, 164-169.

114 D. Liu, J.-H. Lei, L.-P. Guo, D. Qu, Y. Li and B.-L. Su, Carbon, 2012, 50, 476-487.

115 J. Xu, D. Ma, Y. Chen, Y. Wang and Y.-X. Li, Microporous Mesoporous Mater., 2017, 241, 72-78.

116 M. Lakshmi Kantam and P. Sreekanth, Catal. Lett., 2001, 77, 241-243.

117 J. Xu, F. Wu, H.-T. Wu, B. Xue, Y.-X. Li and Y. Cao, Microporous Mesoporous Mater., 2014, 198, 223-229.

118 F. Su, M. Antonietti and X. Wang, Catal. Sci. Technol., 2012, 2, 1005-1009.

119 B. S. Balaji, M. Sasidharan, R. Kumar and B. Chanda, Chem. Commun., 1996, 707-708.

120 M. Sasidharan and R. Kumar, J. Mol. Catal. A: Chem., 2004, 210, 93-98.

121 B. S. Balaji and B. M. Chanda, Tetrahedron, 1998, 54, 1323713252.

122 S. van Donk, E. Bus, A. Broersma, J. H. Bitter and K. P. de Jong, Appl. Catal., A, 2002, 237, 149-159.

123 R. E. Morris, S. J. Weigel, N. J. Henson, L. M. Bull, M. T. Janicke, B. F. Chmelka and A. K. Cheetham, J. Am. Chem. Soc., 1994, 116, 11849-11855.

124 W.-Q. Xu, Y.-G. Yin, S. L. Suib, J. C. Edwards and C.-L. Oyoung, J. Phys. Chem., 1995, 99, 9443-9451.

125 S. Chavan, A. Pasupathy, S. Shengule, V. Shinde and A. Ramanathan, ARKIVOC, 2005, 162-168.

126 C. Mottet, O. Hamelin, G. Garavel, J.-P. Deprés and A. E. Greene, J. Org. Chem., 1999, 64, 1380-1382.
127 L. I. Koval, V. I. Dzyuba, O. L. Ilnitska and V. I. Pekhnyo, Tetrahedron Lett., 2008, 49, 1645-1647.

128 M. Gianotti, G. Martelli, G. Spunta, E. Campana, M. Panunzio and M. Mendozza, Synth. Commun., 2000, 30, 1725-1730.

129 G. B. Dharma Rao, B. Anjaneyulu and M. P. Kaushik, $R S C$ Adv., 2014, 4, 43321-43325.

130 G. B. Dharma Rao, B. N. Acharya and M. P. Kaushik, Tetrahedron Lett., 2013, 54, 6644-6647.

131 S. K. Karmee and A. Chadha, Synth. Commun., 2005, 35, 1151-1160.

132 R. J. Gillespie, T. E. Peel and E. A. Robinson, J. Am. Chem. Soc., 1971, 93, 5083-5087.

133 S. P. Chavan, P. K. Zubaidha, S. W. Dantale, A. Keshavaraja, A. V. Ramaswamy and T. Ravindranathan, Tetrahedron Lett., 1996, 37, 233-236.

134 S. A. Patwardhan and S. U. K. H. Dev, Synthesis, 1974, 348349.

135 B. Das, P. Thirupathi, I. Mahender, V. S. Reddy and Y. K. Rao, J. Mol. Catal. A: Chem., 2006, 247, 233-239.

136 V. K. S. Pappu, A. J. Yanez, L. Peereboom, E. Muller, C. T. Lira and D. J. Miller, Bioresour. Technol., 2011, 102, 4270-4272.

137 R. Pal, T. Sarkar and S. Khasnobis, ARKIVOC, 2012, 570609.

138 S. P. Chavan, Y. T. Subbarao, S. W. Dantale and R. Sivappa, Synth. Commun., 2001, 31, 289-294.

139 S. Padhi and A. Chadha, Synlett, 2003, 639-642.

140 V. Dalla, J. P. Catteau and P. Pale, Tetrahedron Lett., 1999, 40, 5193-5196.

141 V. Dalla, P. Cotelle and J. P. Catteau, Tetrahedron Lett., 1997, 38, 1577-1580.

142 N. Remme, K. Koschek and C. Schneider, Synlett, 2007, 491-493.

143 P. Baumhof, R. Mazitschek and A. Giannis, Angew. Chem., Int. Ed., 2001, 40, 3672-3674.

144 J.-I. Sakaki, S. Kobayashi, M. Sato and C. Kaneko, Chem. Pharm. Bull., 1989, 37, 2952-2960.

145 T. Saravanan and A. Chadha, Synth. Commun., 2011, 41, 2350-2358.

146 J. S. Yadav, B. V. S. Reddy, A. D. Krishna, C. S. Reddy and A. V. Narsaiah, J. Mol. Catal. A: Chem., 2007, 261, 93-97.

147 S. Mallakpour and M. Dinari, in Green Solvents II: Properties and Applications of Ionic Liquids, ed. A. Mohammad and D. Inamuddin, Springer Netherlands, Dordrecht, 2012, pp. 132.

148 Z. S. Qureshi, K. M. Deshmukh, M. D. Bhor and B. M. Bhanage, Catal. Commun., 2009, 10, 833-837.

149 W. Bo, Y. L. Ming and S. J. Shuan, Tetrahedron Lett., 2003, 44, 5037-5039.

150 A. C. H. Weber, T. C. Batista, B. Gonçalves, C. R. L. Hack, L. M. Porciuncula, T. G. M. Treptow, C. D. R. M. D'Oca, D. Russowsky and M. G. M. D'Oca, J. Am. Oil Chem. Soc., 2016, 93, 1399-1406.

151 Y. M. Ren, Z. C. Wu, R. C. Yang, T. X. Tao, J. J. Shao, Y. G. Gao, S. Zhang and L. Li, Adv. Mater. Res., 2013, 781784, 259-262. 
152 B. P. Bandgar, L. S. Uppalla and V. S. Sadavarte, Synlett, 2001, 1715-1718.

153 S. P. Chavan, R. R. Kale, K. Shivasankar, S. I. Chandake and S. B. Benjamin, Synthesis, 2003, 2695-2698.

154 Y. Ren and C. Cai, Synth. Commun., 2010, 40, 1670-1676.

155 B. P. Bandgar, A. M. Hashmi and S. S. Pandit, J. Chin. Chem. Soc., 2005, 52, 1101-1104.
156 B. P. Bandgar, V. Sadavarte and L. Uppalla, Chem. Lett., 2001, 894-895.

157 B. P. Bandgar, V. S. Sadavarte and L. S. Uppalla, Synlett, 2001, 1338-1340.

158 N. Inahashi, T. Fujiwara and T. Sato, Synlett, 2008, 605-607. 